\title{
Maturation in Atlantic salmon (Salmo salar, Salmonidae) : a synthesis of ecological, genetic, and molecular processes
}

\section{Mobley, Kenyon B.}

2021-09

Mobley , K B , Aykanat , T, Czorlich , Y, House , A, Kurko , J , Miettinen , A , Moustakas-Verho , J , Salgado , A , Sinclair-Waters , M , Verta , J-P \& Primmer , C R 2021 , ' Maturation in Atlantic salmon (Salmo salar, Salmonidae) : a synthesis of ecological, genetic, and molecular processes ' , Reviews in Fish Biology and Fisheries, vol. 31 , no. 3 , pp. 523-571 . https://doi.org/10.1007/s11160-021-09656-w

http://hdl.handle.net/10138/333165

https://doi.org/10.1007/s11160-021-09656-w

cc_by

publishedVersion

Downloaded from Helda, University of Helsinki institutional repository.

This is an electronic reprint of the original article.

This reprint may differ from the original in pagination and typographic detail.

Please cite the original version. 


\title{
Maturation in Atlantic salmon (Salmo salar, Salmonidae): a synthesis of ecological, genetic, and molecular processes
}

\author{
Kenyon B. Mobley (D) - Tutku Aykanat • Yann Czorlich (1) Andrew House (i) • \\ Johanna Kurko - Antti Miettinen (D) J Jacqueline Moustakas-Verho (D) \\ Andrés Salgado $\cdot$ Marion Sinclair-Waters $\cdot$ Jukka-Pekka Verta $($ ib \\ Craig R. Primmer $D$
}

Received: 10 November 2020/ Accepted: 19 April 2021/Published online: 7 June 2021

(C) The Author(s) 2021

\begin{abstract}
Over the past decades, Atlantic salmon (Salmo salar, Salmonidae) has emerged as a model system for sexual maturation research, owing to the high diversity of life history strategies, knowledge of trait genetic architecture, and their high economic value. The aim of this synthesis is to summarize the current state of knowledge concerning maturation in Atlantic salmon, outline knowledge gaps, and provide a roadmap for future work. We summarize the current state of knowledge: 1) maturation in Atlantic salmon
\end{abstract}

Tutku Aykanat, Yann Czorlich, Andrew House, Johanna Kurko, Antti Miettinen, Jacqueline Moustakas-Verho, Andrés Salgado, Marion Sinclair-Waters, Jukka-Pekka Verta are listed alphabetically

K. B. Mobley $(\bowtie) \cdot$ T. Aykanat · Y. Czorlich .

A. House - J. Kurko - A. Miettinen .

J. Moustakas-Verho · A. Salgado .

M. Sinclair-Waters · J.-P. Verta · C. R. Primmer

Organismal and Evolutionary Biology Research Program,

Faculty of Biological and Environmental Sciences,

University of Helsinki, PO Box 56, 00014 Helsinki,

Finland

e-mail: kenyon.mobley@helsinki.fi

Y. Czorlich

Norwegian Institute for Nature Research (NINA),

NO-7485 Trondheim, Norway

C. R. Primmer

Institute of Biotechnology, Helsinki Institute of Life

Science (HiLIFE), University of Helsinki, Helsinki,

Finland takes place over the entire life cycle, starting as early as embryo development, 2) variation in the timing of maturation promotes diversity in life history strategies, 3) ecological and genetic factors influence maturation, 4) maturation processes are sex-specific and may have fitness consequences for each sex, 5) genomic studies have identified large-effect loci that influence maturation, 6) the brain-pituitary-gonadal axis regulates molecular and physiological processes of maturation, 7) maturation is a key component of fisheries, aquaculture, conservation, and management, and 8) climate change, fishing pressure, and other anthropogenic stressors likely have major effects on salmon maturation. In the future, maturation research should focus on a broader diversity of life history stages, including early embryonic development, the marine phase and return migration. We recommend studies combining ecological and genetic approaches will help disentangle the relative contributions of effects in different life history stages to maturation. Functional validation of large-effect loci should reveal how these genes influence maturation. Finally, continued research in maturation will improve our predictions concerning how salmon may adapt to fisheries, climate change, and other future challenges.

Keywords Brain-pituitary-gonadal axis - Genomewide association mapping - Life history stage $\cdot$ Life history traits $\cdot$ Puberty $\cdot$ Reproduction 


\section{Introduction}

Sexual maturation (hereto forward maturation) is a key process necessary for reproduction. Maturation encompasses a variety of developmental, physiological, and behavioral processes ultimately leading to reproductive capacity. Maturation processes are energetically costly, and therefore maturation involves trade-offs with other fitness components such as growth and survival (Bernardo 1993; Roff 1993; Stearns 1992). It is well known that various environmental factors can influence maturation and some, such as dietary requirements for normal reproductive development, are ubiquitous. Recent research has revealed how maturation is shaped by the underlying genetic architecture demonstrating that key molecular pathways are shared among a variety of vertebrate species (Barson et al. 2015; Laan et al. 2002; Perry et al. 2014). Currently, maturation research is flourishing and a variety of studies aimed at understanding the relative contributions of ecological and genetic factors on maturation processes are underway.

The timing of maturation contributes to the remarkable variation in the life history strategies of organisms (Healy et al. 2019) and is highly variable both within and among fishes (He and Stewart 2001). Time from birth to maturity can be as short as three weeks in turquoise killifish, Nothobranchius furzeri (Vrtílek et al. 2018), while spiny dogfish, Squalus acanthias, can take over 35 years for half of the adults to mature (Saunders and McFarlane 1993). Maturation may be highly variable within and among populations due to various ecological and genetic influences (e.g., Reznick et al. 2006) and the presence of alternative reproductive strategies (Gross 1996; Taborsky 2008). Salmonids, in particular, exhibit high variation in the timing of maturation within species and this variation is responsible for the remarkable life history diversity in this family of fishes (Stearns 1992).

Atlantic salmon, (Salmo salar L. 1759, Salmonidae) is an emerging model system for vertebrate maturation research (Fig. 1). Salmonids have slow development times, long lifespans, and reproduce later in life, and therefore offer a natural contrast to species that occupy the fast-end of the pace-of-life continuum (Damsgård et al. 2019; Healy et al. 2019) Ample genomic resources, including a high-quality genome assembly (Lien et al. 2016), and the identification of shared molecular pathways for vertebrate maturation make inquiries concerning the genetic basis of maturation possible (Barson et al. 2015; Laan et al. 2002; Perry et al. 2014). The timing of maturation in Atlantic salmon is under strong selection and can aid our understanding of evolutionary processes such as the genetic architecture of adaptive traits, local adaptation, and sexual conflict (Mank 2017; Mobley et al. 2019; Oomen et al. 2020). Further, salmon embryos are larger and develop slower than current model fishes (Gorodilov 1996, 2010) making specific embryonic developmental endpoints easier to target for developmental biology.

Life history traits vary widely across populations and latitudes and are particularly variable in landlocked populations (Hutchings et al. 2019). Atlantic salmon exhibit high diversity in life history strategies due, in part, to considerable variation in the timing of maturation and the number of reproductive episodes (iteroparity vs. semelparity) and the potential for males to participate in reproduction at the parr stage (Einum et al. 2002; Erkinaro et al. 2019; Hutchings et al. 2019; Jonsson and Jonsson 1993, 2011; Thorpe 2007). For example, up to 120 different life histories have been reported among anadromous Atlantic salmon in a single river across a 40 year time series (Erkinaro et al. 2019). Maturation in Atlantic salmon is strongly influenced by ecological and genetic factors that affect the duration of particular life stages (Barson et al. 2015; Good and Davidson 2016; Jonsson and Jonsson 2011). Combined, these features make Atlantic salmon an excellent system for addressing questions concerning the causes and consequences of variation in maturation (Barson et al. 2015; Dodson et al. 2013; Jonsson and Jonsson 2011; Stearns 1992).

Atlantic salmon have additional key features that make them an appealing species for maturation research. For instance, their economic importance means that hatchery facilities for common-garden rearing and controlled treatments are abundant (Fleming et al. 1996; Skaala et al. 2019). There are also numerous well-monitored natural systems that provide detailed long-term data on maturation strategies and/ or reproductive success over their distribution range (Bacon et al. 2015; Chaput et al. 2018; Erkinaro et al. 2019; Jonsson et al. 1990; McGinnity et al. 2003). Further, genomic resources for this species are welladvanced, with a high quality genome assembly (Lien et al. 2016), commercially-available single nucleotide polymorphism (SNP) arrays (Barson et al. 2015), and 


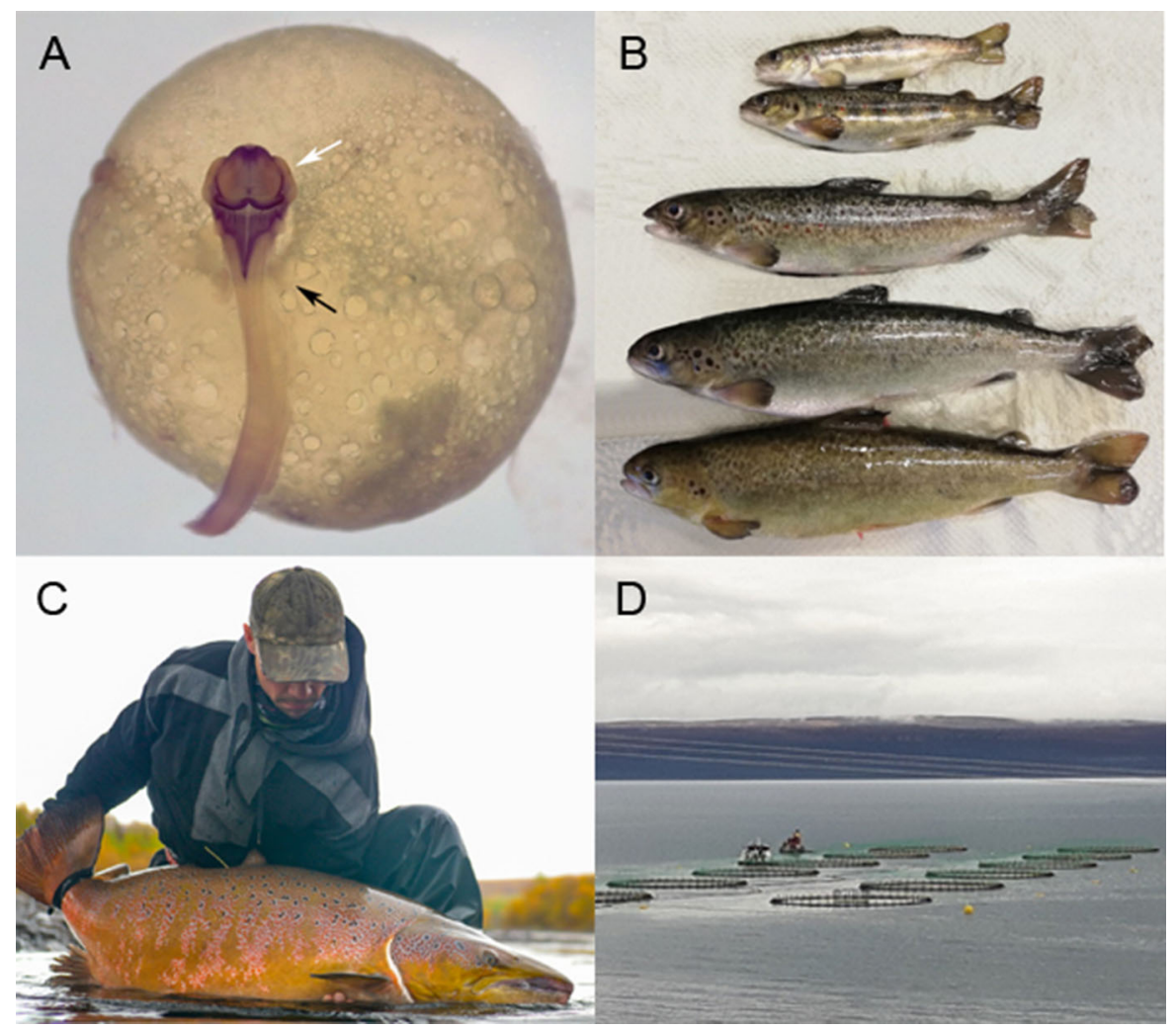

Fig. 1 Atlantic salmon in maturation research. A) Slow development times and large embryo size make Atlantic salmon a good model system for developmental biology. Pictured an Atlantic salmon embryo from the eyed-egg stage stained for the expression of the gene notch $1 \mathrm{~b}$, which is seen in the developing central nervous system (white arrow indicates to eye, black arrow indicates pectoral fin). Image by J. Moustakas-Verho. B) Atlantic salmon show remarkable life history variation. Two year-old male mature parr (top two) represent an alternative reproductive strategy and are smaller than mature post-smolt

ongoing initiatives to improve functional genome annotation (Macqueen et al. 2017). Historical scale archives containing up to hundreds of thousands of samples are available for a number of populations. These scale archives provide access to historical composition of life history variation as well as genetic material (Czorlich et al. 2018; Erkinaro et al. 2019; Johnston et al. 2013; Nielsen and Hansen 2008; Perrier et al. 2013)(Fig. 2).

Understanding maturation in Atlantic salmon has a number of practical benefits. Atlantic salmon aquaculture is a multi-billion dollar industry where early maturation in cultivation results in significant economic losses (Good and Davidson 2016). Further, wild populations have significant socio-economic males (bottom three) of the same age reared in common-garden conditions. Image by A. House. C) Maturation affects a variety of life history traits including body size and reproduction. Longterm monitoring of natural populations can aid conservation and management programs. Image by M. Ellmen. D) Atlantic salmon are an economically important species. Maturation research may help to increase sustainability of exploited fish stocks and yield in commercial aquaculture. Image by $\mathrm{K}$. B. Mobley

importance: they are an important component of indigenous cultures and artisanal fisheries (COSEWIC 2010; Lam and Borch 2011). Atlantic salmon are also a primary target of recreational and commercial fisheries that brings significant income to remote regions (Pokki et al. 2018). For example, the annual value of recreational fishing trips to a single remote Atlantic salmon river system ranges from $€ 2.6$ to 3.7 million (Pokki et al. 2018). Moreover, information concerning the timing of maturation is needed for developing accurate models for sustainable recreational and commercial fisheries (Kuparinen and Hutchings 2017, 2019; Kuparinen and Merilä 2007; Oomen et al. 2020) and for predicting evolutionary 
change as a result of exploitation and climate change (de Roos et al. 2006).

In this synthesis, we review recent advances in the study of maturation in Atlantic salmon. We first provide an overview of maturation at different life history stages. We then summarize the current state of knowledge of the ecological factors, genetic architecture, and molecular and physiological processes that direct maturation. We also provide a guide to practical considerations of maturation to use in conservation, management, and aquaculture efforts. Looking forward, we outline key fields for future research to help fill critical knowledge gaps. We conclude with recommendations to solve outstanding questions concerning maturation.

\section{Definitions}

Alevin Recently hatched juveniles that still retain a yolk sac.

Condition factor The relationship between body length and somatic mass used as a proxy for nutritional status and health.

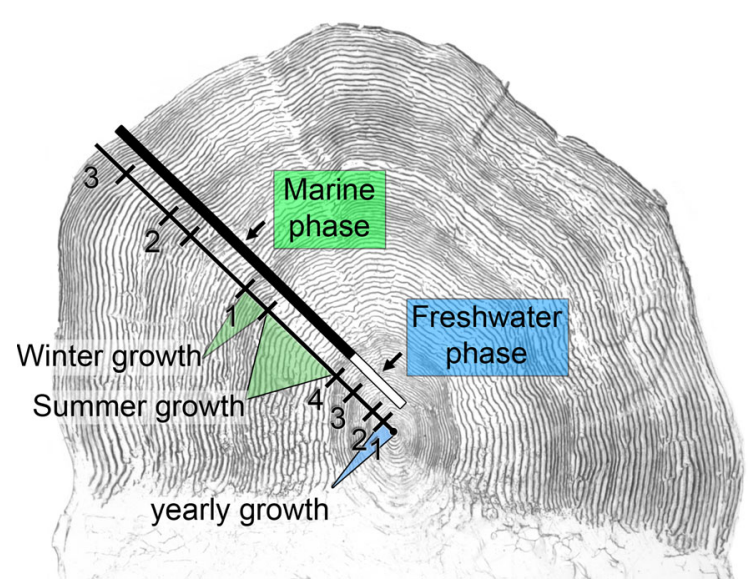

Fig. 2 Salmon scale samples contain important life history information. Time spent in the freshwater phase (freshwater age) and marine phase (sea age) can be accurately calculated based on scale growth rings (circuli). Repeat spawning (iteroparous) individuals can also be identified by scale samples. Location, weight, body size, and sex of the individual are often recorded at the time of collection. DNA of sufficient quality for genetic analyses can be extracted from scales (Johnston et al. 2013). This adult spent four years in the freshwater phase (blue), and three years in the marine phase (green), before it was collected on the spawning ground. Image of scale, Natural Resources Institute Finland (Luke)
Maturation Developmental, physiological, morphological, and behavioral processes leading to reproductive capacity.

Freshwater age The amount of time an individual spends in fresh water prior to smoltification, measured in years. Also known as river age or smolt age.

Fry Free-swimming juveniles that have absorbed their yolk sac and have begun to feed independently.

Genome-wide association study (GWAS) Study using a set of molecular markers (most often SNPs) covering the entire genome aiming to identify genetic variant(s) associated with a phenotypic trait.

Grilse Adult that has returned to fresh water to spawn after spending one winter at sea.

Kelt An adult individual that has recently spawned, often in poor condition.

Mature male parr Male parr with mature gonads capable of reproduction. Also known as precocious parr.

Parr Juveniles that are independently feeding in fresh water. Commonly identified by vertical stripes and colored spots.

Post-smolt A marine-phase pre-adult that has spent less than one winter in the marine environment.

Puberty Development of mature gonads and gametes and other secondary sexual characteristics.

Quantitative trait locus (QTL) A locus that correlates with phenotypic trait variation in a population.

Repeat-spawn Marine-phase adults that spawn in two or more years. Also known as previous-spawner or iteroparous adults.

Return migration Returning from the marine environment to fresh water to spawn after a variable number of years at sea. Also known as spawning migration.

Sea age The amount of time an individual spends in the marine environment prior to returning to fresh water to spawn, commonly measured in sea winters (SW). Also known as sea age at maturity. Individuals that spend a portion of their life at sea before returning to spawn are called anadromous adults.

Single nucleotide polymorphism (SNP) A molecular marker representing variation in a single base-pair of DNA. Currently the most commonly used type of molecular marker.

Smolt A parr that has undergone smoltification to migrate from fresh water to the marine environment. 
Smoltification The physiological, morphological, and behavioral processes enabling transition from fresh water to the marine environment.

Spermiation Late stage of spermatogenesis when mature sperm are released from Sertoli cells.

Timing of maturation Age at which an individual reaches reproductive capacity. Also known as age at first reproduction.

\section{Maturation in life history stages}

Maturation in Atlantic salmon takes place over several distinct phases of their life cycle. The traditional view was that maturation begins at puberty. This transition involves the development of functional gonads, the production of viable gametes and the development of secondary sexual traits related to reproduction. However, it is now recognized that developmental processes initiated during embryonic development can also influence maturation via sex-specific gene expression and maternal effects (e.g., Jonsson and Jonsson 2018; Thorpe 1994; von Schalburg et al. 2011). Moreover, Atlantic salmon have the ability to reproduce at different times throughout the life cycle and may renew this ability annually as an adult (Thorpe 2007). Based on these observations, we take an inclusive view of maturation and include maturation processes that begin after fertilization, through puberty until reproductive capacity, and these processes may be renewed cyclically until reproductive senescence or death.

\section{Life cycle of Atlantic salmon}

Atlantic salmon have a complex life cycle consisting of distinct juvenile, adult, and reproductive life history stages (Fig. 3). Atlantic salmon are generally anadromous, although populations of non-anadromous (i.e., 'landlocked') salmon that spend their entire life cycle in fresh water occur in northern Europe and eastern North America (reviewed in Hutchings et al. 2019). Sexually mature anadromous adults reproduce in fresh water during the fall and winter months. Fertilization of eggs takes place externally in gravel nests (redds) excavated by females in river beds (Fleming and Einum 2011; Jonsson and Jonsson 2011). Developing embryos spend a variable amount of time in the gravel bed before hatching the following spring as alevins.
Post-hatching, alevins continue to gain nutrition from the yolk sac for several weeks and remain in the relative safety of the redd. Once the yolk sac is fully absorbed several weeks to months after hatching, alevins 'swim-up' from the redd, becoming fry, and commence feeding. Fry then develop into parr, shifting from a diet of microscopic invertebrates to larger invertebrate prey (Jonsson and Jonsson 2011). Parr remain in fresh water for a variable number of years before transitioning to the marine phase. The morphological, physiological, and behavioral transformation to migrate from the fresh water to the marine phase is known as smoltification (Jonsson and Jonsson 2003, 2011; McCormick et al. 1998). However, some males may develop mature gonads and participate in reproduction at the parr stage, prior to smoltification (Fleming and Reynolds 2004; Fleming 1996). These mature male parr represent an alternative male reproductive strategy (Gross, 1996; Myers 1984). Females initiate maturation during or after smoltification (Fjelldal et al. 2018) but typically do not obtain reproductive capacity until after several months at sea. In the marine phase, salmon spend a number of years feeding and growing at an accelerated rate compared to the freshwater phase (Friedland and Haas 1996; Nicieza and Braña 1993; Salminen 1997). The most common maturation strategy is to obtain sexual maturity after a return migration to fresh water after a varying number of years (1-5 SW) spent in the marine environment (Erkinaro et al. 2019; Jonsson and Jonsson 2011). Atlantic salmon can repeat-spawn and a small portion of Atlantic salmon may return to spawn over multiple years (Fleming and Einum 2011; Hutchings and Morris 1985; Jonsson and Jonsson 2011).

\section{Freshwater phase}

The freshwater phase is characterized by embryonic development, hatching, and growth until smoltification. Several aspects of growth and development in the freshwater phase have strong effects on maturation. For example, larger eggs develop faster and hatch earlier than smaller eggs (Einum 2003; Gilbey et al. 2005). Earlier hatching times give rise to larger alevins and fry that can be more dominant and have a competitive fitness advantage (Einum 2003; Gilbey et al. 2005; Metcalfe and Thorpe 1992). For example, it has been shown that a difference of less than one 


\section{Freshwater phase}

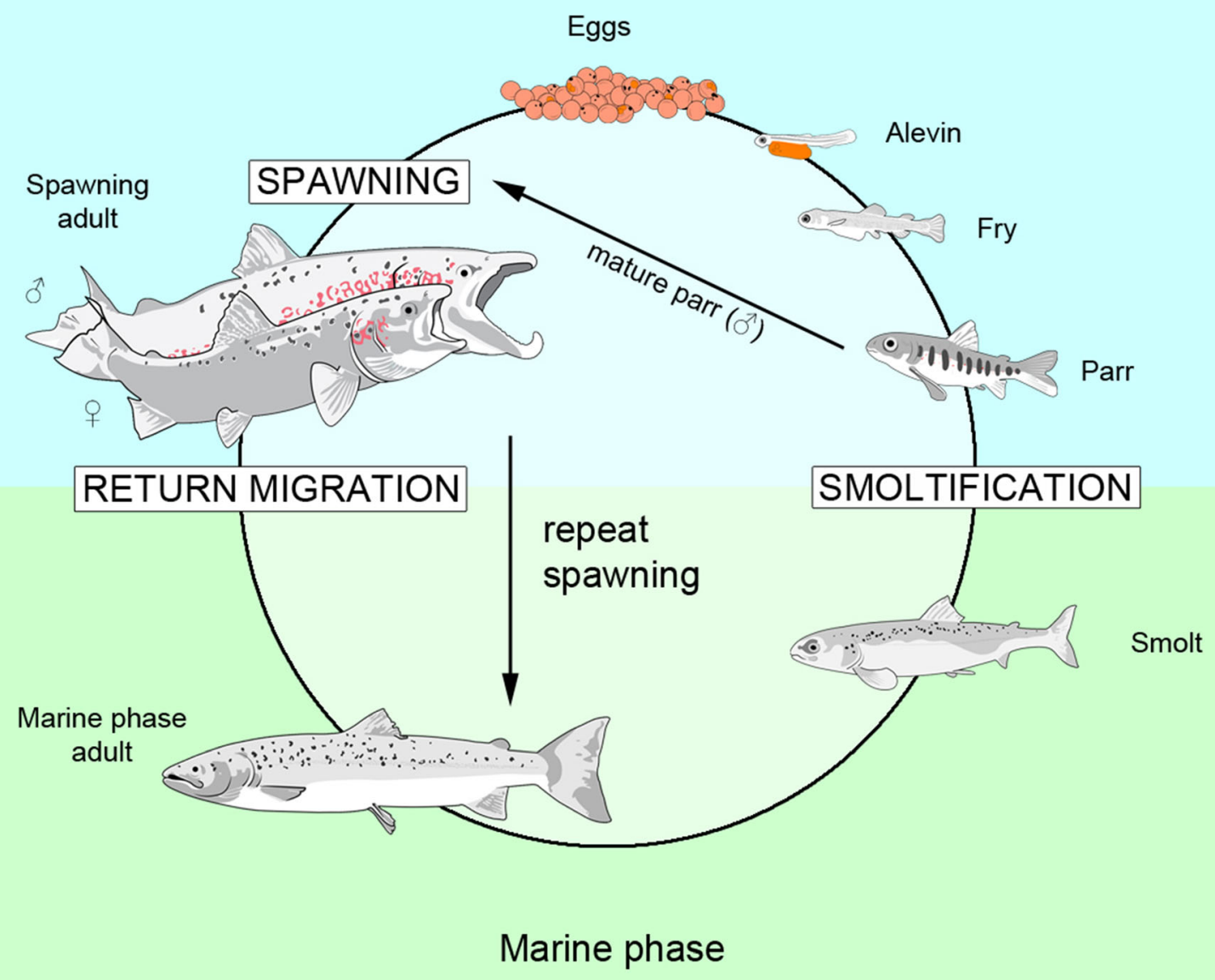

Fig. 3 Atlantic salmon life cycle

week in commencement of first feeding can spell the difference between smolting in the natal year or spending two summers in fresh water (Metcalfe and Thorpe 1992). Maternal effects may contribute to this phenomenon as larger and older females generally have larger eggs (Heinimaa and Heinimaa 2004; Kazakov 1981; Van Leeuwen et al. 2016) and higher offspring survivorship (Einum and Fleming 2000). Paternal effects on egg size may also play a role in maturation (Houde et al. 2010; Pakkasmaa et al. 2001) and influence juvenile growth (Garant et al. 2002; Van Leeuwen et al. 2016).
Freshwater age is highly variable within and among populations, ranging from one to eight years after hatching (Erkinaro et al. 2019; Friedland and Haas 1996; Økland et al. 1993). In general, freshwater age increases with latitude due to a shorter growing season (Metcalfe and Thorpe 1990). Freshwater age is largely determined by growth in the freshwater phase and affects maturation by influencing growth in the marine phase (Jonsson and Jonsson 2007; Metcalfe 1998; Thorpe 1986). For example, faster growth in the freshwater phase increases the chance of an earlier transition to the marine environment (Metcalfe 1998; Thorpe 1986) and a higher chance of male parr 
maturation (Aubin-Horth and Dodson 2004; Thorpe 1986). Smaller smolt size, in turn, can result in faster growth in the marine phase (Jonsson and Jonsson 2007).

\section{Mature male parr}

During the freshwater phase, male parr may become sexually mature prior to the annual spawning season (reviewed in Fleming 1996; Hutchings and Myers 1994). The percentage of mature male parr in different populations varies widely, ranging from completely absent to all individuals sampled (Heinimaa and Erkinaro 2004; Myers 1984, 1986). The cause for variation in parr maturation is likely a combination of population-specific ecological and genetic factors influencing growth. Faster growth and larger size at hatching increases the potential for males to mature at the parr stage (Aubin-Horth and Dodson 2004; Thorpe 1986). However, once males start to mature as parr, growth is decreased by two fold compared to immature parr (Thorpe 1986; Whalen and Parrish 1999) presumably because they are allocating resources to reproduction rather than growth. Male parr maturation is costly in the wild and reduces the probability of the male surviving and smolting the following year by as much as 44\% (Letcher et al. 2002; Myers 1984; Whalen and Parrish 1999). This lowered probability of survival is also likely a result of investment into reproduction. However, a number of experimental studies have not found an association with male parr maturation and the probability of smolting (Debes et al. 2020; Duston and Saunders 1997) suggesting that these two processes may be decoupled.

Mature male parr participate in reproduction $(\mathrm{Ba}-$ cles et al. 2018; Richard et al. 2013; Saura et al. 2008; Taggart et al. 2001; Tentelier et al. 2016; Weir et al. 2010). The reproductive contributions of male mature parr can vary greatly among different populations. On the high end of the spectrum, mature male parr sired up to $87 \%$ of offspring in the Nivelle River, France (Grimardias et al. 2010). However, the individual contributions of mature male parr tend to be smaller than anadromous adult males, on average. For example, compared to mature male parr, anadromous males successfully mated four times and sired 12 times more offspring in the same Nivelle River population (Tentelier et al. 2016). Similarly, anadromous males were estimated to have sired $8-10$ fold more offspring than mature male parr in an experiment with wild caught Canadian fish (Jones and Hutchings 2002). Body size may play a role in mature male parr reproduction. For instance, a strong positive correlation between parr body size and reproductive success was reported in at least one breeding experiment (Thomaz et al. 1997). However, other studies have found no relationship (Jones and Hutchings 2002) or a negative relationship (Tentelier et al. 2016) between parr body size and reproductive success. We are now beginning to understand the genetic factors responsible for mature male parr maturation (Lepais et al. 2017; Verta et al. 2020) and detailed information from multi-generational pedigrees and longitudinal studies may help shed light on this topic in the future.

\section{Smoltification}

Smoltification is an important stage in salmon life history demarcating the transition from freshwater to marine phases in anadromous salmon. The age at smoltification is a function of growth and body size obtained in the freshwater phase and ecological and genetic factors. During smoltification, juveniles undergo morphological, physiological, and behavioral changes to enable the transition to the marine environment. Smolts take on a silvery coloration and become more streamlined (Jonsson and Jonsson 2011). Physiological transformation includes changes in lipid storage and ion-regulation enabling physiological adaptation to higher salinity (Sheridan 1989). Hormones such as prolactin, growth hormone (Gh), insulin-like growth factor (Igf), and cortisol, increase during smoltification (Sheridan 1989). Smolts lose their positive rheotactic behavior (facing upstream) in order to migrate to sea (Specker et al. 2000; Veselov et al. 1998). In some instances, the process of smolting is reversed (i.e., desmoltification) and these fish remain in the freshwater phase until conditions are met for resmoltification (Fraser et al. 2019; Hansen et al. 1989; Thorpe 1994).

The age at smoltification is likely determined by physiological trade-offs in the freshwater environment associated with growth-resource availability. Previous studies have shown that time spent in the freshwater phase is similar between the sexes and larger, faster growing parr tend to smolt earlier than smaller, slower growing parr (Jonsson and Jonsson 2011; Thorpe 1986, 1994; Thorpe et al. 1998). However, smolt size 
is positively correlated with freshwater age; fast growing parr smolt at an earlier age and therefore smaller size in Norwegian salmon (Einum et al. 2002; Økland et al. 1993). Thorpe et al. (1998) proposed that a suite of developmental thresholds and growth parameters such as weight and lipid levels determine smolt timing. Juveniles that have sufficient overwinter lipid stores will smolt the following spring, while those that do not postpone smoltification (Metcalfe 1998; Thorpe et al. 1998).

Among anadromous salmon, females generally mature in the marine phase after the smolting process. Males, on the other hand, can mature before or after smolting. Mature male parr do not appear to smolt in the same year (Thorpe and Morgan 1980). This observation suggests that males do not have enough energy to support maturation and smolting within the same year. However, males that smolt can mature at sea within the same year (Thorpe and Morgan 1980).

The age at smoltification has direct effects on sea age and reproductive fitness. Earlier smolting individuals tend to spend more time at sea before returning to rivers to spawn (Erkinaro et al. 2019; Jonsson and Jonsson 2011; Salminen 1997) and have higher reproductive fitness due to generally achieving larger size (Mobley et al. 2020). However, smolting early potentially exposes these individuals to higher predation at sea, highlighting a trade-off between smolting and survival (McCormick et al. 1998). There may also be a sex-specific relationship between growth and time spent in fresh water. For example, females that spend more time in fresh water show reduced pre- and postsmolt growth (Einum et al. 2002), and suffer a reduction in reproductive success (Mobley et al. 2020), signifying a sex-specific trade-off between growth at sea, reproductive fitness, and the time spent in fresh water.

\section{Marine phase}

The marine phase is associated with rapid growth and fat accumulation that subsequently fuels gonadal development and maturation (O'Connell et al. 2006). Maturation in the marine phase is suggested to be a threshold response that is triggered by body size and/ or condition during the spring and fall (Jonsson et al. 2013). Larger body size at the onset of seaward migration and faster post-smolt growth is generally associated with younger sea age (e.g., Chaput et al.
2018; Hutchings and Jones 1998; Jonsson and Jonsson 2007; Salminen 1997). However, in Baltic Atlantic salmon, smaller smolt size is associated with faster growth followed by earlier maturation, suggesting that the relationship between post-smolt size and maturation may be population-specific (Jonsson and Jonsson 2007).

The marine phase is marked by high mortality, which, in turn, may affect the timing of maturation (Olmos et al. 2019). Tagging studies estimate mortalities as high as 70 to 93\% (Armstrong et al. 2018; Gregory et al. 2018; Hutchings and Jones 1998; Michielsens et al. 2006; Peyronnet et al. 2008; Strøm et al. 2019; Webb et al. 2007). Marine survival of Atlantic salmon is size- and age-dependent with orders of magnitude higher mortality rates at the post-smolt stage, compared to older and larger adults (Chaput et al. 2003, 2018; Michielsens et al. 2006). High mortality in the marine phase may confer a selective advantage to earlier maturation, such that higher probability of survival before reproduction may offset the advantage of being older and larger at maturity (Hard et al. 2008; Mobley et al. 2020; Thorpe 2007).

Return migration and spawning

During the return migration, Atlantic salmon return to fresh water to spawn, often to their natal rivers. This ability is known as homing (Hendry et al. 2003; Quinn 1993). Atlantic salmon commonly spend one to three years (but up to 5 years) in the marine environment before returning to fresh water to spawn for the first time (Jonsson and Jonsson 2011; Webb et al. 2007). Every additional year in the marine environment results in doubling of individual mass; individuals returning after one year are typically $1-3 \mathrm{~kg}$ and 50-65 cm, compared to $10-20 \mathrm{~kg}$ and $>100 \mathrm{~cm}$ after spending three or more years at sea (Hutchings and Jones 1998; Mobley et al. 2020). The main determinants of return migration timing are not well understood but are likely a mixture of ecological factors, genetics, and physiological status.

Females typically spend more years at sea than males (Barson et al. 2015; Mobley et al. 2020; Niemelä et al. 2006a). This additional time is required as females need approximately six times more energy than males for gonad development and egg production (Fleming 1996; Jonsson et al. 1997). In general, large, multi-seawinter adults arrive earlier on the spawning 
grounds (Armstrong et al. 2018; Harvey et al. 2017; Jokikokko et al. 2004; Jonsson et al. 1990; Jutila et al. 2003; Niemelä et al. 2006a; Quinn et al. 2006; Shearer 1990). This may have fitness consequences as early arriving adults may have an advantage in competition for limited spawning sites (Vähä et al. 2011).

Fecundity, the number of offspring (reproductive success) and the number of mating partners (mating success), increases with larger body size and later timing of maturation (Fleming 1998, 1996; Heinimaa and Heinimaa 2004; Mobley et al. 2020, 2019). The timing of maturation in Atlantic salmon represents a classic evolutionary trade-off: individuals that spend more time at sea before returning to fresh water to spawn have higher reproductive success due to their larger size but also have a higher risk of mortality prior to first reproduction (Fleming and Einum 2011; Mobley et al. 2020). Increased reproductive success among older, and therefore larger, individuals is potentially due to their increased competitive ability on the spawning grounds. Differences in competitive ability are likely mediated by size- and age-related differences in aggression and courtship behaviors, gamete competition, and mate choice (Auld et al. 2019; Fleming 1998; Gage et al. 2004; Mjølnerod et al. 1998). For example, body size affects dominance hierarchies, with larger females defending high quality spawning areas [e.g., fast flowing water (Crisp and Carling 1989)] and thus obtaining higher mating and reproductive success (Fleming 1996; Fleming and Einum 2011). Larger males also compete more successfully for access to nesting females (Fleming 1996, 1998; Fleming and Gross 1994). There is also the potential for sex-specific selection and/or sexually antagonistic selection (e.g., sexual conflict) over reproduction to affect maturation in Atlantic salmon (Barson et al. 2015; Mobley et al. 2020).

Repeat spawning and reproductive senescence

In some populations of Atlantic salmon, a proportion of adults may return to spawn in several different years, although the number of these repeat-spawners is generally low $(<10 \%)$ (Fleming and Reynolds 2004; Fleming 1996). Individuals that repeat spawn usually overwinter in fresh water following their first spawning event prior to returning to sea and are known as kelts. Currently, reproductive senescence (Lemaître and Gaillard 2017) is unknown in Atlantic salmon and they are assumed to reproduce throughout their lifetime. For example, one of the oldest recorded Atlantic salmon is a 14-year-old female from the Teno River with four spawning migrations and a total of six years at sea prior to capture (Erkinaro et al. 2019). A 14 year-old individual has also been reported among landlocked salmon (Hutchings et al. 2019).

\section{Alternative reproductive strategies}

Males with distinct sexual maturation phenotypes coexist in many salmon populations (Fleming 1996; Hutchings and Myers 1994). This phenotypic diversity can give rise to different male reproductive strategies based on size and maturation at different life-history phases (Aubin-Horth and Dodson 2004; Hutchings and Myers 1994). For example, anadromous males guard and court females, while mature male parr attempt to sneak copulations without investing in courtship and mate defense (Fleming 1998; Gage et al. 1995; Hutchings and Myers 1994). Compared to anadromous males, mature male parr have significantly smaller gonads in terms of absolute size, a greater proportion of motile spermatozoa, and greater sperm adenosine triphosphate (ATP) content (Vladić 2001; Vladić et al. 2002). Thus, mature parr invest relatively more in sperm quality and sperm numbers in relation to body size than anadromous males in order to compete for fertilizations. Evidence supports the adoption of a particular reproductive strategy being a threshold trait and may be genetically determined in different populations (Hutchings 2011; Hutchings and Myers 1994; Piché et al. 2008).

In populations that have polymorphism in sea age, there is a strong positive correlation between sea age, and therefore body size, and reproductive fitness (Mobley et al. 2020). However, smaller anadromous males may be able to obtain some reproductive success by sneaking copulations or mimicking female behaviors allowing them to remain near spawning pairs (Fleming and Einum 2011; Foote et al. 1997). Females do not appear to display alternative reproductive strategies. Females may mature at a small size in some landlocked populations (Gibson et al. 1996; Hutchings et al. 2019), although evidence for females to mature as parr is scant (Bagliniere and Maisse 1985; Power 1958). 


\section{Ecological factors affecting maturation}

A variety of abiotic and biotic ecological factors influence maturation in Atlantic salmon, and these factors generally reflect the habitats and conditions encountered during different life history phases. Here, we present ecological patterns and processes that have been shown to affect maturation.

Freshwater phase

Numerous environmental factors can influence embryonic development and survival, which in turn can influence maturation processes in later life history stages (Table 1). For example, developing embryos are sensitive to temperature, oxygen levels, and sedimentation (Hamor and Garside 1976; Julien and Bergeron 2006; Peterson et al. 1977). Normal embryonic development takes place within a narrow temperature range with high mortality at low and high extremes (Hamor and Garside 1976). Under experimental conditions, higher incubation temperatures during embryonic development increase growth and performance in juveniles (Burgerhout et al. 2017; Finstad and Jonsson 2012), that in turn may affect reproductive allocation in adults (Finstad and Jonsson 2012; reviewed in Jonsson and Jonsson 2014; 2016; Jonsson et al. 2014). However, faster development comes at a cost to growth, as embryos incubated in warmer water are generally smaller than those raised in lower temperatures (Peterson et al. 1977). Incubation temperature does not appear to influence growth to first feeding (Peterson and Martin-Robichaud 1989). Jonsson and Jonsson (2018) reported that embryos experimentally reared in warmer water temperatures delayed their return spawning migration by two weeks demonstrating that incubation temperature influences maturation in the marine phase.

Temperature continues to be important for growth, physiology, and behavior during the alevin and parr stages (Adams and Thorpe 1989; reviewed in Elliott and Elliott 2010; Koskela et al. 1997). Metabolic processes are sensitive to environmental changes, and food consumption correlates positively with water temperature (Elliott 1991; Koskela et al. 1997; OlignyHébert et al. 2015). Higher temperature may also increase male parr maturation (Debes et al. 2019; Fjelldal et al. 2011), although this temperature effect is not found in all studies (Baum et al. 2005).
Water flow rate can also influence juvenile growth (reviewed in Finstad et al. 2011). An increase in water flow generally results in increased food abundance but a decrease in the capture efficiency of prey (Metcalfe et al. 1997). Moreover, competition for food resources is intense and salmon fry disperse to alleviate intraspecific competition (Brännäs 1995; Gibson 1993). Juvenile salmon become territorial and individuals compete with each other for optimal habitat (Keenleyside and Yamamoto 1962). Here, the supposition is that individuals that are more competitive occupy better habitat and grow faster than those that do not. Earlier feeding fry are more dominant, and therefore individuals that hatch earlier than others may outcompete and mature earlier than their conspecifics (Metcalfe and Thorpe 1992). However, emerging earlier from the redd may come at a cost of higher predation risk (Brännäs 1995).

\section{Smoltification}

Photoperiod length, signaling changes in season, is an important cue for smoltification (McCormick et al. 2002, 2007; Metcalfe and Thorpe 1990; Saunders and Henderson 1970). Photoperiod affects hormonal levels such as insulin-like growth factor (Igf), and growth hormone that are associated with smoltification (McCormick et al. 2002). Experiments increasing temperature and photoperiod demonstrate that these factors interact to increase growth and maturation during and after smoltification (Fjelldal et al. 2011; Imsland et al. 2014; McCormick et al. 2002, 2007). Food restriction (Thorpe and Metcalfe 1998) and reduced water flow (Hosfeld et al. 2008) can also increase the time to smoltification.

A recent common garden study that partitioned genetic and environmental effects found that environmental factors such as water temperature were important for smoltification. However, for a given temperature, genetic factors were more important than environmental effects in predicting smoltification probability (Debes et al. 2020).

Marine phase

Numerous ecological factors may influence salmon maturation during the marine phase (Table 1). However, due to the vast geographical distances that salmon cover at this stage (O'Connell et al. 2006), it is 
Table 1 Examples of ecological factors affecting maturation in Atlantic salmon. Studies are listed chronologically according to life history stage and factor with a summary of the major findings

\begin{tabular}{|c|c|c|c|}
\hline $\begin{array}{l}\text { Phase/ } \\
\text { Stage }\end{array}$ & Factor(s) & Summary of findings & References \\
\hline \multicolumn{4}{|c|}{ Freshwater Phase } \\
\hline Embryo & $\begin{array}{l}\text { Temperature, } \\
\text { oxygen, } \\
\text { water exchange }\end{array}$ & $\begin{array}{l}\text { Increased incubation temperature increased development rate and } \\
\text { decreased survival. Developmental rate and survival increase with } \\
\text { increasing dissolved oxygen and with increasing rate of water } \\
\text { exchange }\end{array}$ & $\begin{array}{l}\text { Hamor and Garside } \\
1976\end{array}$ \\
\hline Embryo & Temperature & Increased incubation temperature decreased size of eyed eggs and alevins & Peterson et al. 1977 \\
\hline Embryo & Temperature & $\begin{array}{l}\text { Incubation temperature prior to swimup had no effect on fry growth } \\
\text { during initial feeding. Increased temperature at first feeding increased } \\
\text { growth of fry }\end{array}$ & $\begin{array}{l}\text { Peterson and } \\
\text { Martin-Robichaud } \\
1989\end{array}$ \\
\hline Embryo & Temperature & $\begin{array}{l}\text { Parr growth was higher in warmer incubation temperature treatments. } \\
\text { Temperature experienced after embryo incubation did not affect } \\
\text { growth performance of juveniles }\end{array}$ & $\begin{array}{l}\text { Finstad and Jonsson } \\
2012\end{array}$ \\
\hline Embryo & Temperature & $\begin{array}{l}\text { Increased incubation temperature influenced egg size and gonad mass of } \\
\text { males and females relative to body size. Incubation temperature did not } \\
\text { influence age at maturity or fecundity in either sex }\end{array}$ & Jonsson et al. 2014 \\
\hline Embryo & Temperature & $\begin{array}{l}\text { Increased incubation temperature in the two months prior to hatching } \\
\text { increased mass of eggs in next-generation }(\mathrm{F} 1) \text { females }\end{array}$ & $\begin{array}{l}\text { Jonsson and Jonsson } \\
2016\end{array}$ \\
\hline Embryo & Temperature & $\begin{array}{l}\text { A } \stackrel{9}{ } \text { increase in incubation temperature doubled the growth as measured } \\
\text { by weight gain in later stages (start feeding } \longrightarrow>\text { adult at harvest). } \\
\text { Variation in epigenetic methylation patterns may help to explain } \\
\text { differences in skeletal muscle growth and thermal plasticity }\end{array}$ & $\begin{array}{l}\text { Burgerhout et al. } \\
2017\end{array}$ \\
\hline Embryo & Temperature & $\begin{array}{l}\text { Embryos incubated in warmer temperatures returned to spawn earlier } \\
\text { than those incubated in colder temperatures as adults }\end{array}$ & $\begin{array}{l}\text { Jonsson and Jonsson } \\
2018\end{array}$ \\
\hline Embryo & Sedimentation & Increases in fine sediment decreases survival of embryos & $\begin{array}{l}\text { Julien and Bergeron } \\
2006\end{array}$ \\
\hline Fry & $\begin{array}{l}\text { Interspecific } \\
\text { competition }\end{array}$ & $\begin{array}{l}\text { Early immerging fry are more at risk to predation than later immerging } \\
\text { fry }\end{array}$ & Brännäs 1995 \\
\hline Fry & $\begin{array}{l}\text { Interspecific } \\
\text { competition }\end{array}$ & $\begin{array}{l}\text { Earlier-feeding fry are dominant over later immerging fry. Dominant } \\
\text { individuals have a higher growth rate }\end{array}$ & $\begin{array}{l}\text { Metcalfe and Thorpe } \\
1992\end{array}$ \\
\hline Parr & Temperature & $\begin{array}{l}\text { Increased temperature increased feed intake and growth rate among } \\
\text { hatchery-raised } 1+\text { parr. Lipid deposition increased with temperature }\end{array}$ & Koskela et al. 1997 \\
\hline Parr & Temperature & Increased temperature increases metabolic rate of parr & $\begin{array}{l}\text { Oligny-Hébert et al. } \\
2015\end{array}$ \\
\hline Parr & $\begin{array}{l}\text { Temperature, } \\
\text { photoperiod }\end{array}$ & $\begin{array}{l}\text { Increase in } 5^{\circ} \mathrm{C} \text { above ambient temperature increased male maturation } \\
\text { and increased oocyte size in females. Advanced photoperiod did not } \\
\text { affect maturation }\end{array}$ & $\begin{array}{l}\text { Adams and Thorpe } \\
1989\end{array}$ \\
\hline Parr & $\begin{array}{l}\text { Water flow, } \\
\text { nighttime light } \\
\text { intensity }\end{array}$ & $\begin{array}{l}\text { Optimal foraging efficiency is influenced by an interaction between } \\
\text { water velocity and nighttime light intensity. On darker nights, parr } \\
\text { prefer slower moving currents and vice versa }\end{array}$ & Metcalfe et al. 1997 \\
\hline Parr & $\begin{array}{l}\text { Interspecific } \\
\text { competition }\end{array}$ & Dominant individuals are associated with optimal growth and survival & $\begin{array}{l}\text { Keenleyside and } \\
\text { Yamamoto } 1962\end{array}$ \\
\hline $\begin{array}{l}\text { Mature } \\
\text { male parr }\end{array}$ & Temperature & $\begin{array}{l}\text { Male parr maturation increases with increased temperature during the } \\
\text { first winter in fresh water }\end{array}$ & $\begin{array}{l}\text { Duston and } \\
\text { Saunders } 1997\end{array}$ \\
\hline Smolt & Photoperiod & $\begin{array}{l}\text { Increased photoperiod during the spring increases growth and } \\
\text { smoltification }\end{array}$ & $\begin{array}{l}\text { Saunders and } \\
\text { Henderson } 1970\end{array}$ \\
\hline Smolt & $\begin{array}{l}\text { Temperature, } \\
\text { photoperiod }\end{array}$ & $\begin{array}{l}\text { Age at smoltification was positively correlated with latitude. } 82 \% \text { of } \\
\text { variation in age at smoltification was explained by growth as a function } \\
\text { of temperature and photoperiod }\end{array}$ & $\begin{array}{l}\text { Metcalfe and Thorpe } \\
1990\end{array}$ \\
\hline
\end{tabular}


Table 1 continued

\begin{tabular}{|c|c|c|c|}
\hline $\begin{array}{l}\text { Phase/ } \\
\text { Stage }\end{array}$ & Factor(s) & Summary of findings & References \\
\hline Smolt & $\begin{array}{l}\text { Temperature, food } \\
\text { availability }\end{array}$ & $\begin{array}{l}\text { A } 2^{\circ} \mathrm{C} \text { temperature difference increased } 1+\text { parr smoltification } \\
\text { probability from } 0.42 \text { to } 0.76 \text {, but a } 6 \text { week food restriction the } \\
\text { previous autumn did not affect smoltification probability }\end{array}$ & Debes et al. 2020 \\
\hline Parr, smolt & $\begin{array}{r}\text { Temperature, } \\
\text { photoperiod }\end{array}$ & $\begin{array}{l}\text { Increased temperature increases growth and osmoregulatory activity. } \\
\text { Photoperiod cues hormonal signaling to advance smoltification }\end{array}$ & $\begin{array}{l}\text { McCormick et al. } \\
2002\end{array}$ \\
\hline Parr, smolt & $\begin{array}{r}\text { Temperature, } \\
\text { photoperiod }\end{array}$ & $\begin{array}{l}\text { Increased photoperiod increases hormones associated with smoltification } \\
\text { in smolts but not parr }\end{array}$ & $\begin{array}{l}\text { McCormick et al. } \\
2007\end{array}$ \\
\hline Parr, smolt & $\begin{array}{l}\text { Photoperiod, } \\
\text { temperature }\end{array}$ & $\begin{array}{l}\text { Higher temperature and continuous light triggers maturation during and } \\
\text { after smoltification in male salmon }\end{array}$ & Fjelldal et al. 2011 \\
\hline $\begin{array}{l}\text { Pre, post- } \\
\text { smolt }\end{array}$ & $\begin{array}{l}\text { Temperature, } \\
\text { photoperiod }\end{array}$ & $\begin{array}{l}\text { Growth and maturation highest in continuous light. Higher proportion of } \\
\text { male maturation was greater under higher temperature. Temperature } \\
\text { and photoperiod interact to determine maturation }\end{array}$ & Imsland et al. 2014 \\
\hline Smolt & Food availability & $\begin{array}{l}\text { Food-restricted individuals are smaller and had lower survivorship } \\
\text { during seawater challenge }\end{array}$ & $\begin{array}{l}\text { Thorpe and Metcalfe } \\
1998\end{array}$ \\
\hline Smolt & Oxygen & $\begin{array}{l}\text { Smolts experimentally exposed to high oxygen environments had higher } \\
\text { growth and were in better condition in both freshwater and saltwater } \\
\text { environments }\end{array}$ & Hosfeld et al. 2008 \\
\hline \multicolumn{4}{|c|}{ Marine phase } \\
\hline $\begin{array}{r}\text { Post-smolt } \\
(<1 \mathrm{SW})\end{array}$ & Temperature & $\begin{array}{l}\text { Post-smolt survival is negatively affected by earlier than normal } \\
\text { increases in temperature in nursery areas }\end{array}$ & Friedland et al. 2003 \\
\hline $\begin{array}{r}\text { Post-smolt } \\
(<1 \mathrm{SW})\end{array}$ & Temperature & $\begin{array}{l}\text { Contrasting evidence that post-smolt growth during the first year at sea is } \\
\text { negatively or positively correlated with sea surface temperature }\end{array}$ & Friedland et al. 2005 \\
\hline $\begin{array}{r}\text { Post-smolt } \\
(<1 \mathrm{SW})\end{array}$ & Temperature & $\begin{array}{l}\text { Temperature significantly influences post-smolt growth rate, feed intake } \\
\text { and feed conversion efficiency and stomach evacuation rate }\end{array}$ & $\begin{array}{l}\text { Handeland et al. } \\
2008\end{array}$ \\
\hline $\begin{array}{r}\text { Post-smolt } \\
(<1 \mathrm{SW})\end{array}$ & $\begin{array}{l}\text { Temperature, food } \\
\text { quality }\end{array}$ & $\begin{array}{l}\text { Increased temperature and increased food quality (higher lipids to protein } \\
\text { ratio) increased growth rate and early male maturation }\end{array}$ & Jonsson et al. 2013 \\
\hline $\begin{array}{l}\text { Grilse } \\
(1 \mathrm{SW})\end{array}$ & Temperature & $\begin{array}{l}\text { Enhanced growth and higher survivorship of } 1 \mathrm{SW} \text { fish correlated with } \\
\text { higher sea surface temperature }\end{array}$ & Friedland et al. 2000 \\
\hline $\begin{array}{l}\text { Grilse } \\
(1 \mathrm{SW})\end{array}$ & Food availability & $\begin{array}{l}\text { Dietary restriction decreased condition factor and maturation of both } \\
\text { male and female grilse }\end{array}$ & $\begin{array}{l}\text { Duston and } \\
\text { Saunders } 1999\end{array}$ \\
\hline $\begin{array}{l}\text { Multi- } \\
\text { seawinter }\end{array}$ & Temperature & $\begin{array}{l}\text { Increased sea temperature is associated with larger numbers of }>1 \mathrm{SW} \\
\text { fish and fewer grilse }(1 \mathrm{SW})\end{array}$ & $\begin{array}{l}\text { Martin and Mitchell } \\
1985\end{array}$ \\
\hline $\begin{array}{r}\text { Post-smolt } \\
(<1 \mathrm{SW})\end{array}$ & Photoperiod & $\begin{array}{l}\text { Artificially longer photoperiods increased growth rate and maturation } \\
\text { percent and advanced ovulation time of females }\end{array}$ & Hansen et al. 1992 \\
\hline Adult & Photoperiod & $\begin{array}{l}\text { Exposing salmon to constant light in winter reduces male maturation } \\
\text { then those exposed to a natural photoperiod }\end{array}$ & Schulz et al. 2006 \\
\hline Adult & $\begin{array}{l}\text { Temperature, } \\
\text { prey availability }\end{array}$ & $\begin{array}{l}\text { Increased seawater temperature at smoltification positively increased } \\
\text { proportion of returning adults and may be related to diet }\end{array}$ & Hvidsten et al. 2009 \\
\hline
\end{tabular}

currently difficult to pinpoint the specific ecological factors influencing maturation at sea (Thorpe et al. 1998). Despite this, a variety of methods such as markrecapture, common garden experiments, and scale analyses (Fig. 2) have provided insights indicating that marine environmental factors including temperature, diet, photoperiod, and salinity all likely contribute to variation in maturation (reviewed in Good and Davidson 2016; Jonsson and Jonsson 2011). Temperature is perhaps the best studied marine environmental factor influencing Atlantic salmon maturation (reviewed in Good and Davidson 2016; 
Jonsson and Jonsson 2011) (Table 1). In general, higher water temperatures are associated with earlier maturation (reviewed in Jonsson and Jonsson 2011). In the wild, warmer conditions during the post-smolt stage are associated with increased mortality in North American Atlantic salmon (Friedland et al. 2005, 2003). In contrast, higher sea surface temperature (SST) in North European coasts is associated with higher growth and survivorship of 1SW grilse (Friedland et al. 2000). The temperature effect on maturation may also interact with nutrition (Friedland et al. 2005). For example, higher temperatures increase the likelihood of early maturation in conjunction with abundant and high quality (e.g., high lipid content) food (Handeland et al. 2008; Jonsson et al. 2013). On the other hand, increased temperatures may enhance basal metabolic activity and negatively affect growth and/or survival via density-dependent effects (Friedland et al. 2003).

Salmon use seasonal changes in photoperiod as a proximate maturation cue during the marine phase (Bromage et al. 2001; Hansen et al. 1992; Schulz et al. 2006; Taranger et al. 2010; Taranger et al. 1999). Experimentally manipulating photoperiods, such as shortening day length earlier in the growing season, can decrease the proportion of fish reaching puberty, while delaying shortening of photoperiods to later results in more maturation (reviewed in Taranger et al. 2010). Maturation is also affected by the interaction between photoperiod and water temperature (Imsland et al. 2014). Elevated temperature combined with continuous light can trigger male Atlantic salmon to mature during and immediately after smoltification (Fjelldal et al. 2011; Imsland et al. 2014). Atlantic salmon spawning rivers cover a wide range of latitudes, and therefore the use of photoperiod as a maturation cue may be population-specific. For instance, photoperiod-associated responses may be mismatched with other environmental cues of maturation, such as temperature, resulting in maladaptive or mismatching phenotypic expression. Although this possibility has not yet been investigated, it may be an important future consideration in the face of climate change.

In general, the initiation of maturation in salmonids is associated with a higher condition factor and therefore is likely dependent upon nutritional status (reviewed in Jonsson and Jonsson 2011). A study on Atlantic salmon in sea cages showed that low food resources during winter affected growth and condition, resulting in lower proportions of earlier maturing salmon (Duston and Saunders 1999). During the postsmolt stage, salmon that feed on marine fish larvae and crustaceans show an increase in growth (Hvidsten et al. 2009; Rikardsen et al. 2004; Salminen et al. 2001). This rapid accelerated growth then influences maturation during the first year at sea (Friedland and Haas 1996; Friedland et al. 2009; Jonsson et al. 2012; Jonsson and Jonsson 2003; Nicieza and Braña 1993).

The effect of diet on maturation is less well known in the open sea, due both to the difficulty in tracking individuals as well as analyzing dietary composition. However, post-smolts are known to be generalist feeders and adopt a more piscivorous diet later in life (Jacobsen and Hansen 2001). Salmon post-smolt appear to utilize high-lipid, high-energy forage fish such as capelin, herring and lantern fishes that may influence early maturation (Rikardsen and Dempson 2010). Currently, it is unclear how genetic factors interact with diet to influence maturation. A recent study by Aykanat et al. (2020) quantified the stomach contents of wild adult Atlantic salmon and demonstrated that the six6 genomic region is linked to gut fullness as well as prey composition, while vgll3 was marginally linked to prey composition. These results suggest that Atlantic salmon is not only a diet specialist governed by genetic variation in six6, but that the genetic basis of diet variation is linked to maturation. Thus, the maturation status of Atlantic salmon populations is likely to have an evolutionary response to alteration in food web structures and changes in resource composition (Bentley et al. 2017; Daufresne et al. 2009; Pershing et al. 2015).

\section{Return migration and spawning}

The timing of the return migration and spawning are influenced by ecological cues such as water temperature and flow regimes (Heggberget 1988; Jonsson et al. 1991; Moore et al. 2012; Thorstad et al. 2008; Webb and McLay 1996) as well as genetic factors (Barson et al. 2015; Sinclair-Waters et al. 2020). Yet, little is known concerning how ecological factors affect maturation processes during this critical period. Ecological factors that influence the distance and duration of the return migration likely have an effect on condition that, in turn, may influence reproductive capacity and ultimately reproductive fitness. 


\section{Genetics of maturation}

Maturation processes during different life history stages were suggested to have a heritable basis over four decades ago (Nævdal et al. 1978). Subsequently, evidence for heritability of maturation processes has accumulated (reviewed in Garcia de Leaniz et al. 2007). For example, the timing of smoltification (Páez et al. 2011), sea age at maturity (Gjerde 1984; Reed et al. 2018; Sinclair-Waters et al. 2020), and male parr maturation (Debes et al. 2019) all have high heritabilities. These results have generated interest in elucidating genomic regions and molecular functions linked to maturation traits. Recently, considerable progress in identifying genes that influence maturation variation in the marine phase have sprung from genome-wide association studies (GWAS) (Ayllon et al. 2015; Barson et al. 2015). However, less is known concerning what genes are responsible for variation in maturation-related processes in other life history stages such as the freshwater phase and smoltification. Likewise, the exact location of genomic polymorphisms within these regions that are causally linked to maturation variation, and the underlying molecular functions are only starting to be unraveled (Verta et al. 2020).

\section{Freshwater phase}

Given the heritability of life history traits such as male parr maturation and smoltification timing, there is concerted interest in identifying genetic variation that underlies these traits. Studies examining tens to hundreds of single nucleotide polymorphism (SNP) markers aimed to identify quantitative trait loci (QTLs) associated with the probability of male parr maturation. For instance, Lepais et al. (2017) identified a handful of QTLs associated with male parr maturation (Table 2). One large effect QTL was found on chromosome 25 that explained $20.6 \%$ of the variation in male parr maturation threshold values (Lepais et al. 2017). This QTL region spans the vgll3 gene, which has been previously identified as a largeeffect locus for Atlantic salmon sea age (Ayllon et al. 2015; Barson et al. 2015) and its association with male parr maturation has recently been further supported in controlled experiments in several salmon populations (Debes et al. 2019; Verta et al. 2020). This result strongly suggests that the vgll3 locus plays a key role in sexual maturity in the freshwater phase. A study by Pedersen et al. (2013) identified multiple QTLs associated with male parr maturation providing further evidence that the trait has a polygenic architecture (Pedersen et al. 2013)(Table 2). However, the mapping of these male parr maturation QTLs is coarse due to low SNP density combined with low recombination rate in male Atlantic salmon (Lien et al. 2011). Pedersen et al. (2013) also identified several genomic regions associated with smoltification timing (Table 2). This included regions containing genes known to undergo expression changes [sparc (Seear et al. 2010)] or potentially influence hormonal changes during smoltification [ $\mathrm{ghrh}$ (McCormick et al. 2010)(Table 2)]. Yet, for both male parr maturation and smoltification, an examination of the link between genotype and phenotype using denser marker coverage (e.g., $>10,000$ SNP markers) is still lacking. A high density genome scan approach that covers a greater number of haplotype blocks is likely to provide a more detailed understanding of the genetic architecture, underlying traits influencing maturation in the freshwater phase of the Atlantic salmon life cycle.

Marine phase

Early studies aiming to identify the genetic basis of sea age generally lacked statistical power and/or genomic coverage sufficient for giving a clear picture of the genomic regions underlying the trait (Table 2). The age of genomics eliminated these limitations, giving rise to several studies that identified a large-effect locus on chromosome 25 that explains up to $39 \%$ of the variation in sea age (Ayllon et al. 2015; Barson et al. 2015)(Fig. 4). The primary candidate gene in the genome region, vgll3 (vestigial-like family member 3), encodes a transcription cofactor involved in cell fate decision in multiple tissues. Verta et al. (2020) found that variation in vgll3 was associated with gene transcript structure in immature male gonad tissue, suggesting vgll3 controls testis differentiation. Vgll3 has been also linked to adipogenesis regulation (Halperin et al. 2013) and therefore also potentially plays a pivotal role in lipid storage and metabolism in Atlantic salmon. The gene is associated with, amongst other things, pubertal timing, growth, and body condition in humans (Cousminer et al. 2013; Elks et al. 2010; Tu et al. 2015). The alternative alleles at the highest associated SNP in the vgll3 locus conferred 
Table 2 Examples of associations between genomic regions and maturation traits in Atlantic salmon. Maturation traits are listed chronologically according to life history stage with a summary of genetic associations found and relevant references.
Positions of genes or loci have the nomenclature "chromosome ID:position" in accordance to the most recent Atlantic salmon genome assembly (ICSASG_v2) (Lien et al. 2016)

\begin{tabular}{|c|c|c|c|}
\hline $\begin{array}{l}\text { Life-history } \\
\text { Stage/Trait }\end{array}$ & Method & $\begin{array}{l}\text { Summary of associations between maturation traits and } \\
\text { genomic regions }\end{array}$ & References \\
\hline \multicolumn{4}{|c|}{ Freshwater phase } \\
\hline $\begin{array}{l}\text { Male parr } \\
\text { maturation }\end{array}$ & QTL analysis (100-300 SNPs) & $\begin{array}{l}3 \text { QTLs reach genome-wide significance* for male parr } \\
\text { maturation: ssa07, ssa12, ssa20. } 4 \text { QTLs reach } \\
\text { chromosome-wide** significance for male parr } \\
\text { maturation: ssa05, ssa09, ssa10, ssa16. }(\mathrm{N}=493)\end{array}$ & $\begin{array}{l}\text { Pedersen } \\
\text { et al. } 2013\end{array}$ \\
\hline $\begin{array}{l}\text { Male parr } \\
\text { maturation }\end{array}$ & QTL analysis (40 SNPs) & $\begin{array}{l}1 \text { QTL reaches genome-wide significance for male parr } \\
\text { maturation: ssa25. } 3 \text { QTLs reach chromosome-wide } \\
\text { significance: ssa14, ssa19, ssa25. }(\mathrm{N}=142)\end{array}$ & $\begin{array}{l}\text { Lepais et al. } \\
2017\end{array}$ \\
\hline $\begin{array}{l}\text { Male parr } \\
\text { maturation }\end{array}$ & $\begin{array}{l}\text { Common garden experiment of parr } \\
\text { with known } v \text { gll3 genotypes }\end{array}$ & $\begin{array}{l}\text { Male parr with the } v g l l 3 * E E \text { genotypes reared in common } \\
\text { garden conditions had a } 10 \times \text { higher maturation } \\
\text { frequency than males with the } v g l l 3 * L L \text { genotype, while } \\
\text { vgll } 3 \text { heterozygotes were intermediate }(\mathrm{N}=384)\end{array}$ & $\begin{array}{l}\text { Verta et al. } \\
2020\end{array}$ \\
\hline $\begin{array}{l}\text { Early } \\
\text { smoltification }\end{array}$ & QTL analysis (100-300 SNPs) & $\begin{array}{l}1 \text { QTL reaches genome-wide significance: ssa23. } 3 \text { QTLs } \\
\text { reach chromosome-wide significance: ssa05, ssa08, } \\
\text { ssa13. }(\mathrm{N}=755)\end{array}$ & $\begin{array}{l}\text { Pedersen } \\
\text { et al. } 2013\end{array}$ \\
\hline \multicolumn{4}{|l|}{ Marine phase } \\
\hline $\begin{array}{l}\text { Early } \\
\text { maturation } \\
(=1 \mathrm{SW})\end{array}$ & QTL analysis (6.5 K SNP array) & $\begin{array}{l}1 \text { QTL reaches chromosome-wide significance for male } \\
\text { early maturation: ssa21. 1 QTL reaches suggestive } \\
\text { significance for male early maturation: ssa10. }(\mathrm{N}=81)\end{array}$ & $\begin{array}{l}\text { Gutierrez } \\
\text { et al. } 2014\end{array}$ \\
\hline $\begin{array}{l}\text { Early } \\
\text { maturation } \\
(=1 \mathrm{SW})\end{array}$ & GWAS (6.5 K SNP array) & $\begin{array}{l}5 \text { SNPS reach genome-wide significance for early } \\
\text { maturation: ssa10, ssa02, ssa12, ssa13, ssa25. }(\mathrm{N}=626)\end{array}$ & $\begin{array}{l}\text { Gutierrez } \\
\text { et al. } \\
\text { (2015 }\end{array}$ \\
\hline $\begin{array}{l}\text { Early } \\
\text { maturation } \\
(=1 \mathrm{SW})\end{array}$ & $\begin{array}{l}\text { Targeted genotyping of } 1 \text { SNP in } \\
\text { tead3 }\end{array}$ & $\begin{array}{l}\text { Association with tead3 }(\text { ssa12:79,047,648-79,123,946) } \\
\text { and early maturation in males }(P \text {-value }=0.046) \text {. } \\
(\mathrm{N}=79)\end{array}$ & $\begin{array}{l}\text { Christensen } \\
\text { et al. } 2017\end{array}$ \\
\hline $\begin{array}{l}\text { Early } \\
\text { maturation } \\
(=1 \mathrm{SW})\end{array}$ & GWAS (50 K SNP array) & $\begin{array}{l}\text { Polygenic and sex-specific genetic architecture. } 13 \mathrm{SNPs} \\
\text { reach chromosome-wide significance for freshwater } \\
\text { maturation. }(\mathrm{N}=1,846) \\
48 \text { SNPs reach chromosome-wide significance for sea age } \\
\text { at maturity. }(\mathrm{N}=2,721) \text {. No overlap between male and } \\
\text { female associations. Two notable candidate loci include } \\
\text { magi2 (ssa10:60,175,081), picalm (ssa11:81,521,399) }\end{array}$ & $\begin{array}{l}\text { Mohamed } \\
\text { et al. } 2019\end{array}$ \\
\hline $\begin{array}{l}\text { Early } \\
\text { maturation } \\
(=1 \mathrm{SW})\end{array}$ & GWAS (50 K SNP array) & $\begin{array}{l}\text { SNPs in } v g l l 3 \text { region that are associated with sea age at } \\
\text { maturity in European lineages were not associated with } \\
\text { early maturation in the North American lineage. } \\
\text { However, the early alleles occurred at low frequencies in } \\
\text { the study samples } \\
3 \text { SNPs on ssa21 reach genome-wide significance for early } \\
\text { maturation } \\
(\mathrm{N}=773)\end{array}$ & $\begin{array}{l}\text { Boulding } \\
\text { et al. } 2019\end{array}$ \\
\hline $\begin{array}{l}\text { Late } \\
\text { maturation } \\
(\geq 2 \mathrm{SW})\end{array}$ & QTL analysis (100-300 SNPs) & $\begin{array}{l}2 \text { QTLs reach chromosome-wide significance: ssa21 and } \\
\text { ssa23. Ssa21 and ssa23 are homologous to chromosomes } \\
\text { with maturation QTLs in rainbow trout. }(\mathrm{N}=81)\end{array}$ & $\begin{array}{l}\text { Pedersen } \\
\text { et al. } 2013\end{array}$ \\
\hline $\begin{array}{l}\text { Late } \\
\text { maturation } \\
(\geq 2 \mathrm{SW})\end{array}$ & GWAS (6.5 K SNP array) & $\begin{array}{l}4 \text { SNPS reach genome-wide significance for late } \\
\text { maturation: ssa01, ssa28 } \\
6 \text { SNPS reach chromosome-wide significance for late } \\
\text { maturation: ssa01, ssa07, ssa16, ssa21. }(\mathrm{N}=466)\end{array}$ & $\begin{array}{l}\text { Gutierrez } \\
\text { et al. } 2015\end{array}$ \\
\hline
\end{tabular}


Table 2 continued

\begin{tabular}{|c|c|c|c|}
\hline $\begin{array}{l}\text { Life-history } \\
\text { Stage/Trait }\end{array}$ & Method & $\begin{array}{l}\text { Summary of associations between maturation traits and } \\
\text { genomic regions }\end{array}$ & References \\
\hline $\begin{array}{l}\text { Late } \\
\text { maturation } \\
(\geq 2 \mathrm{SW})\end{array}$ & QTL analysis (6.5 K SNP array) & $\begin{array}{l}1 \text { QTL reaches chromosome-wide significance for late } \\
\text { maturation: ssa18 } \\
(\mathrm{N}=195)\end{array}$ & $\begin{array}{l}\text { Gutierrez } \\
\text { et al. } 2014\end{array}$ \\
\hline Sea age & Isozyme analysis (6 loci) & $\begin{array}{l}\text { Non-random distribution of alleles at } 1 \text { isozyme locus, } \\
\text { MEP-2, in } 1 \text { SW vs multi-SW individuals. } \\
(\mathrm{N}=291-648)\end{array}$ & $\begin{array}{l}\text { Consuegra } \\
\text { et al. } 2005\end{array}$ \\
\hline Sea age & GWAS $220 \mathrm{~K}$ SNP array & $\begin{array}{l}\text { Strong association with vgll3 } \\
\text { (ssa25:28,654,947-28,659,019) and sea age at } \\
\text { maturation. Evidence of sex-dependent dominance at } \\
\text { vgll3 locus. }(\mathrm{N}=1,404)\end{array}$ & $\begin{array}{l}\text { Barson et al. } \\
2015\end{array}$ \\
\hline Sea age & $\begin{array}{l}\text { GWAS pooled sequencing. Targeted } \\
\text { sequencing of } 2 \text { SNPs in vgll3 }\end{array}$ & $\begin{array}{l}\text { Strong association with } v g l l 3 \\
\text { (ssa25:28,654,947-28,659,019) and sea age at maturity. } \\
74 \text { significant SNPs }(0.1 \% \text { FDR) outside vgll3 region: } \\
\text { ssa01-ssa07, ssa09-24, ssa27-29. ( } \mathrm{N}=20 \text { per pool, } 6 \\
\text { pools) }\end{array}$ & $\begin{array}{l}\text { Ayllon et al. } \\
2015\end{array}$ \\
\hline Sea age & $\begin{array}{l}\text { Targeted genotyping of } 2 \text { SNPs in } \\
\text { vgll3 region }\end{array}$ & $\begin{array}{l}\text { Correlation between } v g l l 3 \text { and probability of maturing } \\
\text { after multi-SW versus after } 1 \mathrm{SW} \text { in three populations in } \\
\text { Québec, Canada. Strength of correlation varies across } \\
\text { study populations. }(\mathrm{N}=1,505)\end{array}$ & $\begin{array}{l}\text { Kusche } \\
\text { et al. } 2017\end{array}$ \\
\hline Sea age & $\begin{array}{l}\text { Analysis of } 2 \text { SNPs genotyped using } \\
\text { combination of qPCR and Sequenom } \\
\text { MassArray }\end{array}$ & $\begin{array}{l}\text { Association between } v g l l 3 \text { and sea age at maturity in males } \\
(\mathrm{N}=308) \text {, but not females }(\mathrm{N}=304) \text {, from the Mowi } \\
\text { strain of domesticated Atlantic salmon }\end{array}$ & $\begin{array}{l}\text { Ayllon et al. } \\
2019\end{array}$ \\
\hline Iteroparity & Targeted genotyping of 194 SNPs & $\begin{array}{l}\text { Individuals homozygous for early allele at } v g l l 3 \text { locus are } \\
2.4 \text { times more likely to spawn a second time than } \\
\text { individuals homozygous for late allele. }(\mathrm{N}=1,135)\end{array}$ & $\begin{array}{l}\text { Aykanat } \\
\text { et al. } 2019\end{array}$ \\
\hline
\end{tabular}

*Genome-wide significance level is determined according to a Bonferroni threshold that accounts for the total number of tested SNPs in the entire genome $(0.05 / \#$ of tested SNPs)

**Chromosome-wide significance level is determined according to a Bonferroni threshold that accounts for only the number of tested SNPs on the focal chromosome (0.05/\# of tested SNPs on focal chromosome)

either early $(E)$ or late $(L)$ sea age (Barson et al. 2015). The vgll3 locus exhibits incomplete sex-specific dominance that may partially resolve potential sexual conflict in this locus. Furthermore, Christensen et al. (2017) found that after accounting for vgll3 genotypes, tead3 (TEA domain transcription factor 3) was associated with early maturation. Tead 3 codes for a transcription factor that the vgll3-encoded cofactor binds to in order to regulate the Hippo signaling pathway (Figeac et al. 2019; Kjærner-Semb et al. 2018; Kurko et al. 2020; Simon et al. 2017). This indicates that the tead 3 gene may affect early maturation via an interaction with $v$ gll3.The effect of $v$ gll3 on sea age appears to be conserved across all European Atlantic salmon lineages (Atlantic, Barents/White Sea and Baltic Sea lineages), and influences sea age in both males and females (Barson et al. 2015)(Table 2). Furthermore, a higher proportion of late maturation alleles of $v g l l 3$ are found in late-maturing females than in early-maturing individuals from populations of North American Atlantic salmon suggesting vgll3 may also be associated with sea age in this lineage (Kusche et al. 2017). Although several GWAS have found a significant association between the vgll3 region and maturation (Aylon et al. 2015, 2019; Barson et al. 2015), others examining single North American aquaculture strains have not (Boulding et al. 2019; Mohamed et al. 2019). This discrepancy may be due to different genetic architecture or variable gene-environment interactions among populations/strains. Alternatively, this may be merely due to low genetic variation at the vgll3 locus in the study samples and/or 

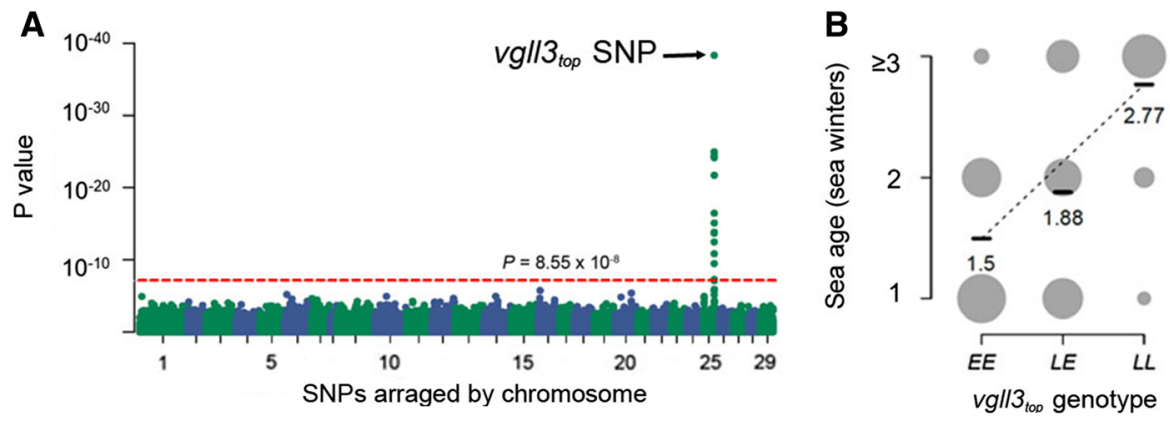

Fig. 4 a Genome-wide association plot (Manhattan plot) of $220 \mathrm{k}$ SNPs showing the association between sea age and SNP loci on chromosome 25. Points above the dashed line indicate significant SNPs associated with sea age. The SNP locus with the strongest association, located near the $v g l l 3$ gene, is labelled

some studies being underpowered to detect such an association.

A second gene in the genome region significantly associated with sea age on chromosome 25 is the akap11 gene encoding the A-kinase anchor protein (Barson et al. 2015), that belongs to a family of A-kinases that are expressed throughout spermatogenesis and is important for sperm motility (Reinton et al. 2000). Akapll and vgll3 have recently been shown to have correlated expression in various juvenile life history stages (Kurko et al. 2020). It is therefore possible that akap 11, along with vgll3, may serve important roles in processes leading to maturation.

A number of loci in other genome regions have been linked with sea age at maturity (Table 2). However, these findings are not ubiquitous across studies linking genetics and maturation timing. Higher-powered association studies involving a broad range of populations and aquaculture strains may help to elucidate why such discrepancies are observed. One recent example examining over 11,000 adults from a single aquaculture strain, identified over 100 candidate genes associated with maturation (Sinclair-Waters et al. 2020). These results demonstrate the importance of increasing sample sizes in order to detect genes of smaller effects. Additionally, new evidence suggests that some genes (e.g., magi 2 \& picalm) may have sexspecific effects on maturation (Mohamed et al. 2019). Studies with large sample sizes and good representation of populations and aquaculture strains including both sexes will be vital to determine the roles of $v g l l 3_{\text {top }}$. b Sea age (in seawinters) in relation to $v g l l 3_{\mathrm{TOP}}$ genotype. Alleles linked with early and late maturation are labelled $E$ and $L$, respectively. Circle areas are proportional to sample size (total $\mathrm{n}=1404$ ). Black bars indicate mean sea age for each genotype class. Data from Barson et al. (2015)

smaller-effect genes and sex-specific genetic architectures for maturation traits in Atlantic salmon.

Sinclair-Waters et al. (2020) identified another large-effect candidate genome region on chromosome 9, including the gene six6 (SIX homeobox 6), that is strongly associated with maturation. Six6 encodes a transcription factor of the brain-pituitary-gonadal axis, and is also associated with height and age-atmaturity in humans (Perry et al. 2014) and puberty in cattle (Cánovas et al. 2014). The same region was also strongly associated with maturation in Johnston et al. (2014) and Barson et al. (2015), but following correction for population stratification, the association signal of significance was lost. This may suggest that the region is associated with a correlated trait (e.g., body size or return migration timing) that is also associated with an environmental factor [e.g., river catchment area, (Pritchard et al. 2018)]. The six6 locus has also been linked with the timing of maturation in several species of Pacific salmon (Waters et al. 2021; Willis et al. 2020) indicating that this genomic region plays a role in maturation and sexual reproduction in other salmonids. The six6 locus is also associated with variation in return migration timing among Scottish Atlantic salmon populations (Cauwelier et al. 2018). Furthermore, a locus ( $\operatorname{lrc} 9$ ) associated with spawning site selection in sockeye salmon, Oncorhynchus nerka, is located in the same significant genomic region as six6 (Pritchard et al. 2018; Veale and Russello 2017). 
Sexual conflict and the vgll3 locus

Atlantic salmon is an interesting model system to investigate questions related to sexual conflict (Barson et al. 2015; Mank 2017). Intra-locus sexual conflict potentially exists at the vgll3 locus (Barson et al. 2015). Differing phenotypic optima for males and females over the sea age and body size at maturation may result in a genetic "tug-of-war" between the early $(E)$ and late $(L)$ alleles at the locus (Barson et al. 2015) (Fig. 5). Repeat-spawning is also linked to the vgll3 locus (Aykanat et al. 2020) and early maturing individuals may recover additional reproductive success if they survive to reproduce again. A survey of 57 populations has shown that vgll3 alleles are maintained at intermediate frequencies in many populations (Barson et al. 2015), which may be indicative of balancing selection, predicted under intra-locus sexual conflict (Connallon and Clark 2014).

An interesting twist to this scenario is the observation of sex-dependent dominance of the vgll3 locus, allowing the maintenance of the two allelic forms of vgll3 in populations of Atlantic salmon (Barson et al. 2015; Kuparinen and Hutchings 2019). Due to the apparent dominance of the $E$ allele in males, $E L$, heterozygote males behave like homozygote $E E$ males by returning to spawn after $1 \mathrm{SW}$, whereas heterozygote females return to spawn at an intermediate age between both homozygotes (Fig. 5). Potential consequences of sex-specific dominance and additive effects on selection at sea inducing variation in sexspecific allele frequency patterns are supported by simulations and empirical data (Czorlich et al. 2018). Future research should investigate the potential causes and consequences of sexual conflict in this species.

\section{Molecular \& physiological processes of maturation}

Besides the basic molecular and physiological processes required to maintain normal development, growth, and homeostasis, several regulatory processes are key for maturation in Atlantic salmon. These processes include hormonal control of maturation, gene expression pathways related to maturation processes, and gonadal development. The brain-pituitarygonadal (BPG) axis is a central player in maturation in vertebrates, including salmon (Taranger et al. 2010). Understanding the molecular and physiological

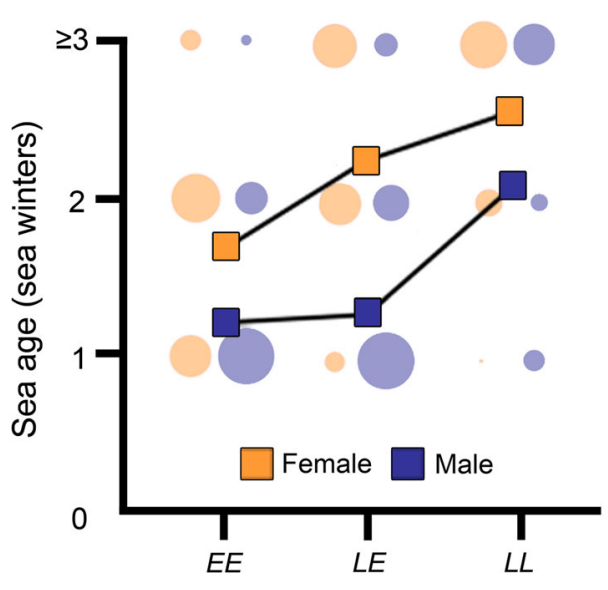

Fig. 5 Sex-specific differences in sea age maturation and incomplete dominance of $v$ gll3 genotypes. Sea age of females $(\mathrm{n}=693)$ and males $(\mathrm{n}=711)$ in relation to vgll3 genotype ( $E=$ early, $L=$ Late). Points indicate predicted average sea age using a logit transformation model (see Barson et al. 2015 for details). Circles are proportional to the number of spawning adults used in the study. Figure based on data from Barson et al. (2015)

processes governing maturation in Atlantic salmon, along with interactions with genetic and ecological factors, helps to pinpoint the key genes and regulatory pathways resulting in maturation variation.

The brain-pituitary-gonadal axis

The BPG axis regulates maturation via neurological and hormonal feedback and is analogous to the hypothalamic-pituitary-gonadal axis in other vertebrates (Ellis 2013). The activation of the BPG axis is induced by different internal and external stimuli, including growth, adiposity, sex hormones, photoperiod, temperature, salinity and social cues (Choi et al. 2014; Gielen et al. 1982; Melo et al. 2014; Taranger et al. 2010). Many of these stimuli are functionally related to growth and/or energy acquisition and storage, which, in turn, affect the rate of lipid acquisition and storage (Jonsson and Jonsson 2003; Rowe et al. 1991; Taranger et al. 2010). The onset of maturation can be modulated by the rate of lipid storage in the body and the specific levels and types of lipids stored, whereby low lipid levels act as a factor limiting early maturity in salmonids (Jenkins et al. 2019; Rowe et al. 1991; Sheridan and Harmon 1994; Silverstein et al. 1997). 
Considerable research has been conducted on understanding how the different components of the BPG axis regulate maturation in salmon and related species. We first consider the brain, pituitary and gonad components of the BPG axis separately and summarize gene expression studies related to the maturation process in Atlantic salmon (Table 3). Finally, we consider molecular and physiological factors affecting variation in maturation timing.

\section{Brain}

The brain is the first organ in the BPG axis that integrates cues of factors affecting maturation. The main brain hormone that induces this axis is gonadotropin-releasing hormone (GnRH) secreted from the GnRH neurons that form during early embryonic development (Parhar et al. 1995). A key molecular mediator of GnRH release in mammals, the neuropeptide kisspeptin, has been examined recently in fish (Ohga et al. 2018), but its role remains controversial. In Atlantic salmon, co-expression of the kisspeptin receptor gene, skissr, and sGnRH3 in the brain indicates that kisspeptin may affect $\mathrm{GnRH}$ secretion directly, primarily during at the onset of maturation and later stages of gonad development (Chi et al. 2017). Different internal and external cues are known to induce the BPG axis and GnRH release, including photoperiod changes which are sensed both in the hypothalamus and saccus vasculosus, a special sensor of seasonal changes in day length in the fish brain (Nakane et al. 2013). Long photoperiod increases expression of both skissr and gnrh3 in the hypothalamus and saccus vasculosus in salmon, suggesting that photosensing has a direct effect on the BPG axis via the kisspeptin system (Chi et al. 2017).

The link between energy stores, especially that of lipids, and reproduction is conserved in vertebrates, and the hormone leptin is one of the molecules conveying such metabolic signals to the brain. Although leptin influences Atlantic salmon fat accumulation, its role seems to be something other than adiposity signaling via the BPG axis, as sexual maturation does not directly induce expression changes in the leptin receptor gene, lepr, in the brain (Trombley et al. 2014). However, long photoperiods reduce leptin receptor A1 gene, AsLRal, expression levels in both the hypothalamus and saccus vasculosus, thereby increasing appetite and food intake which, in turn, results in higher growth rate (Chi et al. 2019).

Mature male parr demonstrate an upregulation in genes involved in energy production and homeostasis, metabolism, growth, and feeding, such as proopiomelanocortin and melanin-concentrating hormone 2 (Aubin-Horth et al. 2005, 2009; Guiry et al. 2010; Kawauchi 2006; Takahashi et al. 2009), and genes regulating lipid metabolism such as apolipoproteins and glycerol-3-phosphate dehydrogenase (Aubin-Horth et al. 2009)(Table 3). In addition to the upregulation of genes associated with energy status and metabolism in mature male parr, differential gene expression patterns are reported in the brain. Some of these associated genes are involved in spatially and temporally correct navigation, maintenance of osmotic balance, body color modification and coping with mechanical and social stress (Table 3). These results indicate that molecular signals originating from the brain prepare salmon physiologically and behaviorally for maturation. Accordingly, expression changes have been observed in genes encoding prolactin involved in migration and osmoregulation (Whittington and Wilson 2013), Na/K ATPase alpha regulating in osmotic balance of neuronal cells (Vornanen and Paajanen 2006), and pro-opiomelanocortin and melanin-concentrating hormone 2 controlling pigmentation (Kawauchi 2006; Takahashi et al. 2009). Additional genes associated with maturation include ependymin which is essential in long-term memory (Piront and Schmidt 1988), as well as vasotocin and isotocin involved in circadian and seasonal cycles, responses to stress, cardiovascular function, osmoregulation and regulation of social behavior (Balment et al. 2006; Chou et al. 2011; Godwin and Thompson 2012; Kasper et al. 2017)(Table 3). Although the details are not well understood, signals from the brain trigger the production and/or release of hormones in the next component of the BPG-axis, the pituitary.

\section{Pituitary}

The pituitary is a key organ translating signals from the brain into endocrine signaling hormones that influence maturation and e.g. regulate gonad and germ cell development. The main pituitary hormones in the BPG axis are two gonadotropins, follicle-stimulating hormone (Fsh) and luteinizing hormone (Lh), which 
Table 3 Examples of gene expression studies related to maturation in Atlantic salmon. Gene expression studies are listed according to target tissue and life history stage comparisons. The method, target tissue, summary of gene expression patterns genes that show differential expression during maturation and relevant references are also listed

\begin{tabular}{|c|c|c|c|}
\hline Comparison & $\begin{array}{l}\text { Method, } \\
\text { target tissue }\end{array}$ & $\begin{array}{l}\text { Summary of gene expression patterns during } \\
\text { maturation }\end{array}$ & References \\
\hline Immature vs. mature male parr & $\begin{array}{l}\text { Microarray, } \\
\text { qPCR } \\
\text { Brain }\end{array}$ & $\begin{array}{l}\text { Prl (prolactin) and pomc (pro-opiomelanocortin), } \\
\text { and other genes in biological processes such as } \\
\text { circadian rhythm, neural plasticity, } \\
\text { reproduction, growth, metabolism, and energy } \\
\text { production and feeding are upregulated in } \\
\text { mature compared to immature parr }\end{array}$ & $\begin{array}{l}\text { Aubin- } \\
\text { Horth } \\
\text { et al. } 2005\end{array}$ \\
\hline Immature vs. mature male parr & $\begin{array}{l}\text { Microarray, } \\
\text { qPCR } \\
\text { Brain }\end{array}$ & $\begin{array}{l}\text { Hbal and hba4 (alpha globin } 1 \text { and } 4), h b b \text { (beta } \\
\text { globin), apoe (apoliporotein E), ciapin1 } \\
\text { (anamorsin), ctsd (cathepsin D), isotocin 2, } \\
\text { vasotocin } 1 \text { and cof2 (cofilin 2) genes are } \\
\text { downregulated and ctnnbip1 (beta-catenin } \\
\text { interacting protein 1), mch2 (melanin- } \\
\text { concentrating hormone 2) and tgfb2 } \\
\text { (transforming growth factor beta 2) are } \\
\text { upregulated among other genes in mature } \\
\text { compared to immature parr }\end{array}$ & $\begin{array}{l}\text { Guiry et al. } \\
2010\end{array}$ \\
\hline $\begin{array}{l}\text { Immature vs. mature male parr, early male and } \\
\text { female migrants (smoltification in present year) } \\
\text { vs. late male and female migrants } \\
\text { (smoltification next year or later) }\end{array}$ & $\begin{array}{l}\text { Microarray } \\
\text { Brain }\end{array}$ & $\begin{array}{l}\text { Globin alpha and beta and retinol binding protein } \\
\text { genes are upregulated both in mature parr and } \\
\text { early migrants compared to immature parr and } \\
\text { late migrants, respectively. Apolipoprotein, } \\
\text { cGMP-phosphodiesterase, class III alcohol } \\
\text { dehydrogenase, ependymin, glycerol-3- } \\
\text { phosphate dehydrogenase, godonadotropin } \\
\text { alpha 1, gonadotropin alpha 2, gonadotropin } \\
\text { beta (Fsh), Na/K ATPase alpha, prolactin, pro- } \\
\text { opiomelanocortin, rod-like opsin, selenoprotein, } \\
\text { somatolactin, somatotropine, thr3 and } \\
\text { transposase genes are upregulated in mature parr } \\
\text { but downregulated in early migrants compared } \\
\text { to immature parr and late migrants, respectively }\end{array}$ & $\begin{array}{l}\text { Aubin- } \\
\text { Horth } \\
\text { et al. } 2009\end{array}$ \\
\hline Immature vs. maturing male parr & $\begin{array}{l}\text { qPCR } \\
\text { Pituitary }\end{array}$ & $\begin{array}{l}\text { Fshb (follicle-stimulating hormone } \beta \text {-subunit) and } \\
\text { lhb (luteinizing hormone } \beta \text {-subunit) are } \\
\text { upregulated in maturing compared to immature } \\
\text { parr. Expression of } f s h b \text { increases during early } \\
\text { spermatogenesis and remains high until late } \\
\text { spermatogenesis but slightly decreases at } \\
\text { spermiation. } L h b \text { expression slightly increases } \\
\text { during early- and mid-spermatogenesis and then } \\
\text { highly raises at late spermatogenesis and peaks } \\
\text { at spermiation }\end{array}$ & $\begin{array}{l}\text { Maugars } \\
\text { and } \\
\text { Schmitz } \\
\text { 2008a }\end{array}$ \\
\hline Immature vs. maturing male parr & $\begin{array}{l}\mathrm{qPCR} \\
\text { Pituitary }\end{array}$ & $\begin{array}{l}\text { Fshb and } l h b \text { are upregulated in maturing } \\
\text { compared to immature parr. Expression of } f s h b \\
\text { declines at late spermatogenesis. Lhb expression } \\
\text { gradually increases during spermatogenesis and } \\
\text { peaks at spermiation }\end{array}$ & $\begin{array}{l}\text { Trombley } \\
\text { et al. } 2014\end{array}$ \\
\hline Immature vs. maturing male parr & $\begin{array}{l}\text { qPCR } \\
\text { Pituitary }\end{array}$ & $\begin{array}{l}\text { Fshb, lhb and gnrhr } 2 b b \alpha \text { are upregulated in } \\
\text { maturing compared to immature parr. } \\
\text { Expression of } g n r h r 2 b b \alpha \text { increases from early to } \\
\text { late spermatogenesis }\end{array}$ & $\begin{array}{l}\text { Ciani et al. } \\
2020\end{array}$ \\
\hline
\end{tabular}


Table 3 continued

\begin{tabular}{|c|c|c|c|}
\hline Comparison & $\begin{array}{l}\text { Method, } \\
\text { target tissue }\end{array}$ & $\begin{array}{l}\text { Summary of gene expression patterns during } \\
\text { maturation }\end{array}$ & References \\
\hline Immature vs. maturing male parr & $\begin{array}{l}\text { ddPCR } \\
\text { Testes plus } \\
9 \text { other } \\
\text { tissues }\end{array}$ & $\begin{array}{l}\text { Temporal analysis of } v g l l 3 \text { expression in ten } \\
\text { tissues across the first year of salmon } \\
\text { development revealed a } 66 \% \text { reduction in } \\
\text { testicular } v g l l 3 \text { expression in maturing male } \\
\text { parr. } v g l l 3 * L L \text { genotype was associated with a } \\
\text { tendency to delay puberty and also with } \\
\text { expression of a rare transcript isoform of } v g l l 3 \\
\text { pre-puberty }\end{array}$ & $\begin{array}{l}\text { Verta et al. } \\
2020\end{array}$ \\
\hline Immature vs. maturing male grilse & $\begin{array}{l}\text { qPCR } \\
\text { Pituitary }\end{array}$ & $\begin{array}{l}\text { Fshb, lhb and gnrhr4 (gonadotropin-releasing } \\
\text { hormone II receptor) are upregulated in } \\
\text { maturing compared to immature grilse. } \\
\text { Expression of } f s h b \text { increases during early- and } \\
\text { mid-spermatogenesis but declines at } \\
\text { spermiation. Lhb expression slightly increases } \\
\text { during early- and mid-spermatogenesis and then } \\
\text { peaks at spermiation. Expression level changes } \\
\text { during spermatogenesis were modest for gnrhr4 }\end{array}$ & $\begin{array}{c}\text { Schulz et al. } \\
2019\end{array}$ \\
\hline Immature vs. maturing male post-smolts & $\begin{array}{l}\text { qPCR } \\
\text { Pituitary }\end{array}$ & $\begin{array}{l}\text { Fshb, lhb and gnrhr4 are upregulated in maturing } \\
\text { compared to immature post-smolts. Expression } \\
\text { of } f \text { shb increases during early and mid- } \\
\text { spermatogenesis while decreases until } \\
\text { spermiation. Lhb and gnrhr4 mRNA levels } \\
\text { increase gradually and peak at spermiation }\end{array}$ & $\begin{array}{l}\text { Melo et al. } \\
2014\end{array}$ \\
\hline Immature vs. maturing female post-smolts & $\begin{array}{l}\text { qPCR } \\
\text { Pituitary }\end{array}$ & $\begin{array}{l}\text { Fshb and } l h b \text { are upregulated in maturing } \\
\text { compared to immature post-smolts. Expression } \\
\text { of } f s h b \text { gradually increases from oil droplet } \\
\text { stage to mid-vitellogenesis with secondary yolk } \\
\text { vesicles and maintains at a high level during late } \\
\text { vitellogenesis with larger oocytes in tertiary } \\
\text { yolk stage. Fshb mRNA level increases again } \\
\text { and remains high during ovulation and post } \\
\text { ovulation. Lhb expression increases gradually } \\
\text { from oil droplet stage to late vitellogenesis and } \\
\text { peaks at the onset of ovulation }\end{array}$ & $\begin{array}{l}\text { Andersson } \\
\text { et al. } 2013\end{array}$ \\
\hline Immature vs. maturing female post-smolts & $\begin{array}{l}\text { qPCR } \\
\text { Pituitary }\end{array}$ & $\begin{array}{l}\text { Sl alpha and sl beta (somatolactin) are } \\
\text { upregulated in maturing compared to immature } \\
\text { post-smolts. Expression of sl alpha and sl beta } \\
\text { increases during late vitellogenesis and again } \\
\text { during ovulation, and decreases post ovulation }\end{array}$ & $\begin{array}{l}\text { Benedet } \\
\text { et al. } 2008\end{array}$ \\
\hline Immature vs. maturing female post-smolts & $\begin{array}{l}\text { qPCR } \\
\text { Pituitary }\end{array}$ & $\begin{array}{l}\text { Gh (growth hormone) is upregulated in maturing } \\
\text { compared to immature post-smolts. Expression } \\
\text { of } g h \text { is increased during early and mid- } \\
\text { vitellogenesis and decreased during ovulation } \\
\text { but raised again post ovulation }\end{array}$ & $\begin{array}{l}\text { Benedet } \\
\quad \text { et al. } 2010\end{array}$ \\
\hline Immature vs. maturing female post-smolts & $\begin{array}{l}\text { qPCR } \\
\text { Ovary }\end{array}$ & $\begin{array}{l}\text { Fshr (follicle stimulating hormone receptor) is } \\
\text { expressed at relatively stable level during } \\
\text { vitellogenesis and maturation but upregulated } \\
\text { post ovulation. Lhcgr (luteinizing hormone } \\
\text { receptor) is upregulated in maturing compared } \\
\text { to immature post-smolts. Expression of lhcgr } \\
\text { gradually increases from oil droplet stage to late } \\
\text { vitellogenesis and ovulation but decreases post } \\
\text { ovulation }\end{array}$ & $\begin{array}{l}\text { Andersson } \\
\text { et al. } 2013\end{array}$ \\
\hline
\end{tabular}


Table 3 continued

\begin{tabular}{|c|c|c|c|}
\hline Comparison & $\begin{array}{l}\text { Method, } \\
\text { target tissue }\end{array}$ & $\begin{array}{l}\text { Summary of gene expression patterns during } \\
\text { maturation }\end{array}$ & References \\
\hline Immature vs. early maturing female post-smolts & $\begin{array}{l}\text { qPCR } \\
\text { Ovary }\end{array}$ & $\begin{array}{l}\text { Vgll3 (vestigial-like family member } 3 \text { ) is } \\
\text { upregulated during early vitellogenesis (early } \\
\text { maturing) compared to oil drop (maturing) stage } \\
\text { in post-smolts }\end{array}$ & $\begin{array}{l}\text { Kjærner- } \\
\text { Semb } \\
\text { et al. } 2018\end{array}$ \\
\hline Immature vs. maturing females & $\begin{array}{l}\text { RNA-seq, } \\
\text { qPCR } \\
\text { Ovary }\end{array}$ & $\begin{array}{l}\text { Inha (protein inhibin alpha chain) is upregulated } \\
\text { in maturing (early vitellogenic) compared to } \\
\text { immature females }\end{array}$ & $\begin{array}{l}\text { Kleppe } \\
\text { et al. } 2020\end{array}$ \\
\hline Immature vs. maturing male parr & $\begin{array}{l}\text { qPCR } \\
\text { Testis }\end{array}$ & $\begin{array}{l}F s h r \text { and } l h r \text { are upregulated in maturing } \\
\text { compared to immature parr. Expression of } f s h r \\
\text { and } l h r \text { increases during early and mid- } \\
\text { spermatogenesis. Fshr mRNA levels peak at } \\
\text { spermiogenesis, but } l h r \text { mRNA levels continue } \\
\text { to rise at spermiation }\end{array}$ & $\begin{array}{l}\text { Maugars } \\
\text { and } \\
\text { Schmitz } \\
\text { 2008a }\end{array}$ \\
\hline Immature vs. mature male parr & $\begin{array}{l}\text { Microarray, } \\
\text { qPCR } \\
\text { Testis }\end{array}$ & $\begin{array}{l}\text { Amh (anti-Müllerian hormone), alpha and beta } \\
\text { globin, colla2 and colla3 (collagen 1A2 and } \\
\text { 1A3), transferrin and zinc finger protein genes } \\
\text { are downregulated and apoe and apoc1 } \\
\text { (apolipoproteins E and C-1), lpl (lipoprotein } \\
\text { lipase), anti-leukoproteinase precursor and six6 } \\
\text { (SIX homeobox 6) are upregulated among other } \\
\text { genes in mature compared to immature parr. } \\
\text { Amh is downregulated in mature compared to } \\
\text { immature adult }\end{array}$ & $\begin{array}{l}\text { Guiry et al. } \\
2010\end{array}$ \\
\hline Immature vs. maturing male parr & $\begin{array}{l}\text { qPCR } \\
\text { Testis }\end{array}$ & $\begin{array}{l}\text { Fflb (FTZ-F1 homolog), 3b-HSD (3b- } \\
\text { hydroxysteroid dehydrogenase/D5-D4- } \\
\text { isomerase), } 11 b \text { - } H S D \text { (11b-hydroxysteroid } \\
\text { dehydrogenase), StAR (steroidogenic acute } \\
\text { regulatory protein), P450scc (cytochrome P450 } \\
\text { cholesterol side-chain cleavage enzyme), } \\
P 450 c 17 \text { (cytochrome P450 17a-hydroxylase/ } \\
17,20 \text {-lyase) and P45011b (cytochrome P450 } \\
11 \text {-hydroxylase) are upregulated in maturing } \\
\text { compared to immature parr. Expression of } 3 b \text { - } \\
H S D, 11 b \text { - } H S D \text { and } P 450 s c c \text { gradually increases } \\
\text { throughout spermatogenesis. P450scc mRNA } \\
\text { levels strongly peak at spermiation. StAR and } \\
P 450 c 17 \text { expression increases during early } \\
\text { spermatogenesis, decreases during mid- } \\
\text { spermatogenesis, increases again during } \\
\text { spermiogenesis and peaks at spermiation. } \\
P 45011 b \text { mRNA levels increase during } \\
\text { spermiogenesis. Amh is downregulated during } \\
\text { early to mid-spermatogenesis and further } \\
\text { spermiogenesis in maturing compared to } \\
\text { immature parr, but reaches its initial level at } \\
\text { spermiation }\end{array}$ & $\begin{array}{l}\text { Maugars } \\
\text { and } \\
\text { Schmitz } \\
2008 b\end{array}$ \\
\hline Immature vs. maturing male parr & $\begin{array}{l}\text { qPCR } \\
\text { Testis }\end{array}$ & $\begin{array}{l}\text { Lepr (leptin receptor) is upregulated in maturing } \\
\text { compared to immature parr. Expression of lepr } \\
\text { increases throughout mid- to late } \\
\text { spermatogenesis }\end{array}$ & $\begin{array}{l}\text { Trombley } \\
\text { et al. } 2014\end{array}$ \\
\hline
\end{tabular}


Table 3 continued

\begin{tabular}{|c|c|c|c|}
\hline Comparison & $\begin{array}{l}\text { Method, } \\
\text { target tissue }\end{array}$ & $\begin{array}{l}\text { Summary of gene expression patterns during } \\
\text { maturation }\end{array}$ & References \\
\hline Immature vs. maturing male grilse & $\begin{array}{l}\text { qPCR } \\
\text { Testis }\end{array}$ & $\begin{array}{l}\text { Fshr, lhr, aral, ara2 (androgen receptor type a } 1 \\
\& \text { 2) and amh are downregulated gradually } \\
\text { during spermatogenesis in maturing compared } \\
\text { to immature grilse. The lowest expression for } \\
\text { these genes is seen at spermiogenesis and } \\
\text { spermiation. Igf3 (insulin-like growth factor } 3 \text { ) } \\
\text { is upregulated in maturing compared to } \\
\text { immature grilse and high levels were maintaned } \\
\text { during progress of spermatogenesis }\end{array}$ & $\begin{array}{l}\text { Schulz et al. } \\
2019\end{array}$ \\
\hline Immature vs. maturing male post-smolts & $\begin{array}{l}\text { RNA-seq, } \\
\text { qPCR } \\
\text { Testis }\end{array}$ & $\begin{array}{l}\text { Igf3 is upregulated and amh downregulated in } \\
\text { maturing testis. Pathways that are enriched in } \\
\text { immature compared to maturing testis include } \\
\text { fatty acid metabolism, biosynthesis of } \\
\text { unsaturated fatty acids, cell cycle, mitophagy, } \\
\text { vegf signaling and progesterone-mediated } \\
\text { oocyte maturation. Enriched pathways in } \\
\text { maturing compared to immature testis include } \\
\text { Wnt signaling, insulin signaling, apelin } \\
\text { signaling, foxo signaling and autophagy }\end{array}$ & $\begin{array}{l}\text { Skaftnesmo } \\
\text { et al. } 2017\end{array}$ \\
\hline Immature vs. maturing male post-smolts & $\begin{array}{l}\text { Microarray, } \\
\text { qPCR } \\
\text { Testis }\end{array}$ & $\begin{array}{l}\text { Insl3 (insulin-like } 3 \text { ) is upregulated and amh } \\
\text { downregulated in maturing compared to } \\
\text { immature post-smolts. Genes inmetabolic, } \\
\text { purine and pyrimidine metabolism, glycerolipid } \\
\text { metabolism, regulation of actin cytoskeleton, } \\
\text { cell cycle and Wnt signaling pathways are } \\
\text { upregulated in maturing compared to immature } \\
\text { post-smolts }\end{array}$ & $\begin{array}{l}\text { Crespo et al. } \\
2019\end{array}$ \\
\hline Immature vs. maturing male post-smolts & $\begin{array}{l}\text { RNA-seq, } \\
\text { qPCR } \\
\text { Testis }\end{array}$ & $\begin{array}{l}\text { The Hippo signaling genes such as vgll3, tead3 } \\
\text { (TEA domain transcription factor } 3 \text { ) and } n f 2 \\
\text { (neurofibromin 2), and amh are downregulated, } \\
\text { and pcna (proliferating cell nuclear antigen) is } \\
\text { upregulated in maturing compared to immature } \\
\text { post-smolts }\end{array}$ & $\begin{array}{l}\text { Kjærner- } \\
\text { Semb } \\
\text { et al. } 2018\end{array}$ \\
\hline Immature vs. mature adult males & $\begin{array}{l}\text { RNA-seq, } \\
\text { qPCR } \\
\text { Testis }\end{array}$ & $\begin{array}{l}\text { Inha is upregulated, while gsdf (gonadal soma- } \\
\text { derived growth factor) is downregulated in } \\
\text { mature compared to immature adults }\end{array}$ & $\begin{array}{l}\text { Kleppe } \\
\text { et al. } 2020\end{array}$ \\
\hline Immature vs. maturing male parr & $\begin{array}{l}\mathrm{qPCR} \\
\text { Liver }\end{array}$ & $\begin{array}{l}\text { Lepal and lepa2 (leptin) are upregulated in } \\
\text { maturing compared to immature parr. } \\
\text { Expression of lepal and lepa } 2 \text { increases } \\
\text { throughout mid- to late spermatogenesis and } \\
\text { peaks at spermiation }\end{array}$ & $\begin{array}{l}\text { Trombley } \\
\text { et al. } 2014\end{array}$ \\
\hline
\end{tabular}

are secreted from specific gonadotropic cells in the pituitary (Nozaki et al. 1990) in response to GnRH stimulation from the brain (Amano et al. 1997). This hormonal signaling has mainly been studied in other salmonid species, but recent gene expression studies have confirmed these findings in Atlantic salmon (Table 3). Upregulation of the gene paralogs encoding the GnRH receptor [gnrhr4 (Melo et al. 2014; Schulz et al. 2019) and gnrhr2bb (Ciani et al. 2020)] is seen in the pituitary of maturing males. Increased expression of $f s h b$ and $l h b$ (coding for Fsh and Lh betasubunits, respectively) is detected in the pituitaries of both maturing males (Ciani et al. 2020; Maugars and Schmitz 2008a; Melo et al. 2014; Schulz et al. 2019; Trombley et al. 2014) and females (Andersson et al. 2013). These studies found that during gametogenesis, 
$f_{s h} b$ expression is highest during early and mid-stage of spermatogenesis and oogenesis. In contrast, expression of $l h b$ peaks at spermiation (Table 3 ) and the onset of ovulation.

Environmental cues affect hormonal signaling in the pituitary. Exposure of salmon males to salt water increases gnrhr4 and $f s h b$ expression, and induces stronger stimulation of the onset of spermatogenesis compared to fresh water (Melo et al. 2014). Decreasing photoperiod induces more efficient $l h b$ expression and, therefore, faster completion of spermatogenesis than longer exposure to light (Melo et al. 2014).

Released gonadotropins circulate in the blood and bind to their corresponding receptors in the developing gonads (testes and ovaries) where they contribute to regulating expression of the gonad-secreted sex hormones (Miwa et al. 1994; Yan et al. 1992). Fsh is mainly required to induce and maintain gonadal growth, as evidenced by increased levels of Fsh in the plasma at the onset of vitellogenesis (yolk formation) and spermatogenesis, while Lh peaks in the plasma during spawning, suggesting that it is required for final gonad maturation (Breton et al. 1998; Gomez et al. 1999; Prat et al. 1996; Suzuki et al. 1988a).

Beyond gonadotropins, additional pituitary hormones affecting gonad development and other processes involved in maturation include the somatotropin hormone family members. For example, genes encoding somatotropin (i.e., growth hormone, Gh) and somatolactin are upregulated in the pituitary of mature females (Benedet et al. 2010, 2008)(Table 3). Both of these hormones are known to influence steroid biosynthesis, gonad development, and spawning (Benedet et al. 2008; Le Gac et al. 1993). More specifically, somatolactin is likely involved in the regulation of body coloration, plasma calcium and phosphate metabolism during vitellogenesis, maturation-induced fasting, and lipid metabolism in oocyte maturation (Benedet et al. 2008).

\section{Gonads}

The final phase of maturation in the BPG axis is the development of mature gonads. Gonadal differentiation starts during embryonic development, and ovaries and testes are already distinguishable a few weeks after hatching (von Schalburg et al. 2011). The main inducers of gonad development are sex hormones stimulated by the pituitary-secreted gonadotropins, Fsh and Lh, which bind to their corresponding receptors in the ovary and testis. In the Atlantic salmon ovary, the Fsh receptor gene, $f s h r$, is expressed at a stable basal level during maturation and upregulated only post ovulation (Andersson et al. 2013). In maturing male parr, fshr expression is upregulated in testis and peaks during late spermatogenesis (Maugars and Schmitz 2008a)(Table 3). These studies also show that the Lh receptor gene, lhcgr, is upregulated in both maturing ovaries and testes and peaks at ovulation and spermiation, respectively. In contrast to maturing parr, in grilse testes, both $f s h r$ and lhcgr downregulate towards the late stages of spermatogenesis (Schulz et al. 2019) (Table 3).

In male salmonids, 11-ketotestosterone $(11 \mathrm{KT})$ is the primary androgen (male sex hormone) (Antonopoulou and Borg 2016). 11KT secretion in testes is induced by Fsh during early spermatogenesis (Maugars and Schmitz 2008a) when it stimulates spermatogonial differentiation with the help of testosterone (T) (Melo et al. 2015). Later in spermiogenesis, the release of $11 \mathrm{KT}$ is mediated by Lh instead of Fsh (Maugars and Schmitz 2008a). In addition to spermatogenesis, $11 \mathrm{KT}$ is also known to influence secondary male, and also female, sexual characteristics in salmonids (Idler et al. 1961; Kudo et al. 2018). During spermiation, the plasma levels of $11 \mathrm{KT}$ and $\mathrm{T}$ decline (Baynes and Scott 1985; Planas and Swanson 1995; Sakai et al. 1989) while levels of the main maturationinducing hormone, Lh-induced $17 \alpha, 20 \beta$-dihydroxy-4pregnen-3-one $(17,20 \mathrm{P})$ increase to finalize sperm maturation (Baynes and Scott 1985; Fitzpatrick et al. 1986; Le Gac and Loir 1988; Planas and Swanson 1995; Sakai et al. 1989; Ueda et al. 1983). 17,20P is also suggested to induce sperm motility in the sperm duct (Miura et al. 1992) and be associated with the control of the ionic composition of seminal plasma (Baynes and Scott 1985).

Fish gonads are comprised of both mitotic (males: Sertoli and Leydig cells; females: granulosa cells) as well as meiotic (spermatozoa, ova) cell types that are connected to the endocrine networks regulating maturation. The function of Sertoli cells in males is to support the differentiation of germ cells into functional sperm and phagocytize residual cell bodies (França et al. 2015). In seasonal breeders such as Atlantic salmon, Sertoli cells also phagocytize unejaculated seminal fluid and spermatozoa. The number 
and function of Sertoli cells in fish including salmon are dynamic and change as a function of maturation status (França et al. 2015).

The early stages of male maturation involve mitotic proliferation of Sertoli cells, required for increases in undifferentiated spermatogonia (Schulz et al. 2005). Sertoli cell proliferation during maturation is connected to endocrine factors such as estrogens, androgens, progestins, and thyroid hormone (Morais et al. 2013; Schulz et al. 2005). Sertoli cells express key genes that control whether or not male germ cells differentiate, undergo meiosis, and mature into functional sperm (Table 3). Along with Fsh, androgenregulated Sertoli cell factors Anti-Müllerian hormone, Amh, insulin-like growth factor 3, Igf3 (sometimes also called igf1), and insulin-like 3, Ins13, constitute a core regulatory network that activates the early stages of spermatogenesis before meiosis (spermatogonial phase) (Crespo et al. 2019; Maugars and Schmitz 2008b; Morais et al. 2017; Nóbrega et al. 2015; Sambroni et al. 2013; Schulz et al. 2019; Skaar et al. 2011; Skaftnesmo et al. 2017). Additionally, expression of genes encoding transforming growth factor beta (TGF-beta) factors are associated with maturation in Sertoli cells: gsdf, gonadal soma-derived growth factor, is downregulated and inha, protein inhibin alpha chain, upregulated in mature testis (Kleppe et al. 2020)(Table 3).

Early gonadal development in females starts with transformation of primordial germ cells into primary oocytes, after which the oocytes stay quiescent and meiosis is stalled until puberty is reached. Pubertal stages include vitellogenesis (growth) and the completion of meiosis, ending in ovulation (Lubzens et al. 2010). Gene expression changes at different stages of oocyte growth indicate that in addition to Fsh, Amh and Gsdf seem to play a role in regulating the onset of female maturity in coho salmon (Luckenbach et al. 2008). In Atlantic salmon, however, gsdf expression has been shown to stay unchanged, but, instead, inha is upregulated in granulosa cells of early vitellogenic ovary during puberty (Kleppe et al. 2020)(Table 3).

In female salmonids, Fsh enhances the production of estradiol (E2) (Montserrat et al. 2004; OppenBerntsen et al. 1994; Suzuki et al. 1988b), that induces zonagenesis and vitellogenesis (eggshelladiata protein and vitellogenin production, respectively) of maturing oocytes (Celius and Walther 1998; Oppen-Berntsen et al. 1992). When approaching ovulation, the levels of
E2 decrease and, instead, Lh stimulates the production of 17,20P (Suzuki et al. 1988b) to induce the final oocyte maturation and ovulation (Fitzpatrick et al. 1986; Nagahama and Adachi 1985; Nagahama et al. 1983; Scott et al. 1982; Suzuki et al. 1988b; Young et al. 1983).

Molecular factors resulting in variation in maturation

One of the most important molecular processes that controls the timing of maturation is cell fate commitment regulation, the potential for cells to proliferate and differentiate into particular kinds (Plusa and Hadjantonakis 2018). From the maturation perspective, this is a key process as it is linked with decisions related to allocating resources between e.g. growth vs gonadal development (Jonsson and Jonsson 2003). Two key molecular pathways, Hippo and Wnt signaling, are known to be involved in this process. These two pathways interact with each other (Varelas et al. 2010) to regulate body axis patterning and organ size during development by controlling cell proliferation, differentiation and migration, and they are conserved in both vertebrates and invertebrates (Halder and Johnson 2011; Meng et al. 2016; Petersen and Reddien 2009; Teo and Kahn 2010). Studies show that both pathways regulate gonad development in Atlantic salmon (Kjærner-Semb et al. 2018; Skaftnesmo et al. 2017).

In Atlantic salmon post-smolts, downregulation of the Hippo signaling genes vgll3 and tead3, both associated with sea age, and neurofibromin 2, nf2, is detected in maturing testis compared to that of immature salmon, whereas the same genes are upregulated in regressing testis (Kjærner-Semb et al. 2018)(Table 3). These findings, combined with the localization of vgll3 expression in testicular Sertoli cells, suggest that Vgll3 and other members of the Hippo signaling pathway may function as inhibitors of Sertoli cell proliferation in immature testis (KjærnerSemb et al. 2018). Further, differences in vgll3 transcript expression have been associated with maturation timing in male parr, suggesting that changes in vgll3 interaction with other transcription factors in the Hippo pathway is at least part of the mechanism translating genetic variation in vgll3 into different age at maturity phenotypes (Verta et al. 2020). A sexspecific expression pattern is seen in the vgll3 
paralogs. For example, the sea age-associated paralog on chm25 is expressed in testis and a second paralog on chromosome 21 is expressed in the ovary (Kurko et al. 2020). In addition to taking part in Sertoli cell proliferation inhibition, is also a central actor in mesenchymal stem cell commitment by inducing chondrocyte and osteocyte differentiation and inhibiting adipocyte maturation as seen in a murine cell line (Halperin et al. 2013). This commitment decision is likely critical to the sexual maturation process of salmon to enable allocation of fat-derived energy for gonad development at the right time. Cell fate commitment regulation by Vgll3 has been suggested to be conducted via actin cytoskeleton assembly control with assistance from Akap11 (Kurko et al. 2020), encoded by another gene associated with sea age in Atlantic salmon.

An additional gene associated with maturation, six6, encodes a transcription factor that has been shown to regulate maturation of the GnRH neurons and expression of $\mathrm{GnRH}$ in the mouse hypothalamus (Larder et al. 2011), as well as transcription of the gonadotropin genes in the gonadotrope cell line in mice (Xie et al. 2015). Its expression has been detected also in the Atlantic salmon brain, including specific expression in the developing pituitary and pineal glands (Moustakas-Verho et al. 2020) and testis (Kurko et al. 2020) and shown to be upregulated in mature parr testis (Guiry et al. 2010), suggesting its importance in the BPG axis of salmon. Genetic variation in six6 may influence differential timing of the BPG axis activation via the role of Six6 in regulating neuronal and hormonal development. Moreover, expression of two genes, slc38a6 and $r t n 1$, encoding proteins involved in neuroendocrine secretion in the BPG axis and located in the same genomic region as six6, correlates with six6 expression in several salmon juvenile life history stages (Kurko et al. 2020). This further emphasizes the importance of this genomic region and the BPG axis in the regulation of maturation.

Physiological status and maturation

After embryonic development, Atlantic salmon fry need to initiate feeding as early as possible to allow for adequate lipid storage which affects the timing of maturation (Rowe et al. 1991). In males, there is a positive correlation between storage lipids and allocation of resources to gonadal development during summer months (Rowe et al. 1991). Fasting during the spring delays maturation because stored lipid reserves are required for maturation the following autumn (Herbinger and Friars 1992; Rowe et al. 1991). If feeding is not sufficient, maturation will be inhibited until the following year (Thorpe 2007).

Leptin has roles in feeding, adiposity, metabolism, and reproduction (Park and Ahima 2015). Leptin is thought to affect food intake in many vertebrate taxa and monitor energy reserves to regulate pubertal development in eutherian mammals (Sprent et al. 2012). Leptin receptor genes are expressed at low levels in testis of non-maturing male parr during periods of fat accumulation and growth (Trombley et al. 2014). In mature males that have already allocated energy from fat stores to developing gonads, leptin is upregulated (Trombley et al. 2014).

Atlantic salmon expend a substantial part of their somatic energy reserves during upstream migration and spawning. For example, the total body lipid content dropped from $11 \%$ before upstream migration to less than $2 \%$ after spawning (Jonsson et al. 1997). A significant component of this large depletion of lipids goes to gametogenesis and reproductive behavior since feeding is arrested during the return migration (Rowe et al. 1991; Thorpe 1994). During this time, females expend $20-25 \%$ of their weight into gonads for egg production, whereas males are invest 3-9\% of body weight into gonads (Rowe et al. 1991; Thorpe 1994).

\section{Practical applications}

Due to the high economic value and significant cultural importance of the species (Houston and Macqueen 2019), we provide an overview of how knowledge of Atlantic salmon maturation may inform conservation and management efforts, commercial and recreational fisheries, and aquaculture.

\section{Conservation of genetic diversity}

Life history features of Atlantic salmon such as having a wide diversity in life history strategies and overlapping generations (Chaput et al. 2006; Erkinaro et al. 2019; Hutchings and Jones 1998) can improve the abundance, genetic diversity, and the ability of 
populations to adapt to new environmental conditions. The presence of individuals with alternative reproductive strategies in a population also has the potential to reduce inbreeding by increasing the occurrence of matings between individuals from different cohorts. For instance, the contribution of mature male parr to spawning has been shown to increase the genetic diversity of populations and effective population size $\left(N_{e}\right)$, as anadromous females are more likely to be older and from a different cohort than their mature male parr mates (Juanes et al. 2007; Perrier et al. 2014). Jones and Hutchings (2002) estimated the reproductive contributions of mature male parr to moderately increase $N_{e}$ in a mating experiment with anadromous adults. In wild populations, Perrier et al. (2014) showed a 1.8 fold increase in the effective number of breeders and Saura et al. (2008) a two to three-fold increase in $N_{e}$ due to mature parr spawning. Perrier et al. (2014) also reported an 11\% increase in the number of alleles in progeny due to contributions of mature male parr. They found that relatedness between mature parr and anadromous females was significantly lower than between anadromous adults, suggesting that alternative reproductive strategies may also reduce inbreeding depression at the population level.

Variation in maturation may improve population genetic diversity. For instance, Vähä et al. (2007) reported that the proportion of late maturing (multi-sea winter) females was the best predictor of genetic diversity among four landscape variables and explained $\sim 80 \%$ of the observed variation in allelic richness at microsatellite loci in several populations of the Teno River in northern Europe. Life history diversity and overlapping generations may also stabilize variance in genetic diversity (Gaggiotti and Vetter 1999; Vähä et al. 2007) and the abundance of individuals over time via the portfolio effect (see also Anderson et al. 2013; Schindler et al. 2010). Simply stated, the portfolio effect is the diversification of risks, in this case, via diverse life-history strategies, reducing the overall impact of negative effects, e.g. environmental disturbances occurring at particular locations and/or during a limited period of time (Schindler et al. 2015; Tilman et al. 1998). Schindler et al. (2010) also exemplified the commercial significance of life history diversity in sockeye salmon $O$. nerka by calculating that losing population and life history diversity would result in ten times more frequent fishery closures.

Fisheries management

Understanding maturation processes is central to fisheries as management programs are often based on estimation of the minimum size required for sexual reproduction (Coggins et al. 2007; Erkinaro et al. 2019; Uusi-Heikkilä et al. 2015). This consideration is particularly important as late-maturing salmon are becoming rarer in many wild Atlantic salmon populations (Chaput 2012; Erkinaro et al. 2019).

Fishery management based on body size limits likely select individuals with different maturation strategies within the same population. In salmon, the situation is complicated because individuals are harvested at different life history stages and maturation states. For example, salmon are fished with immature individuals in marine feeding grounds, or with mature or maturing individuals are in coastal waters or in the river. Mixed-stock fisheries may alter the timing of maturation differently in different populations if maturation strategies differ among them. The influence of male parr maturation may also be relevant to fisheries management. For instance, it is estimated that approximately $60 \%$ of the adult male salmon production is lost due to male parr maturation in a natural population in southwest Newfoundland (Myers 1984). As a result, fisheries may have different ecological and evolutionary consequences for each population of the mixed stock, unless both the population of origin and the life history composition of each population of the mixed stock are taken into account. Molecular and scale age approaches now enable detailed life history information to be estimated with relatively straightforward approaches (e.g., Johnston et al. 2013, 2014; Vähä et al. 2017). However, the economic loss due to male parr maturation in wild populations remains an open question.

Fishing pressure targeting individuals differently according to their size may play a role in the observed reduction in the frequency of late-maturing Atlantic salmon (Czorlich et al. 2018, 2021). The effect of genetic changes associated with fishing, i.e., fishinginduced evolution (Conover et al. 2005; Reznick and Ghalambor 2005), on salmon sea age may be more difficult to predict and interpret than has been previously assumed based on phenotypic and 
ecological data (Kuparinen and Hutchings 2017, 2019). The results of Kuparinen and Hutchings (2017, 2019) and Oomen et al. (2020) demonstrate how the outcomes of size-selective fishing can depend on the genetic architecture behind the trait being selected for, and highlight the unpredictability of the evolutionary outcomes of different fishing strategies.

The timing of the salmon return migration preceding the reproductive season is used to determine the time window of when fishing is permitted in a riverine fishery in northern Finland and Norway (Erkinaro et al. 2019) and also the mixed-stock fishery in the northern Baltic Sea (Suuronen and Jounela 2010). This is because females and large, multi-sea winter, and repeat-spawning salmon tend to return to rivers early in the season (Erkinaro et al. 1997; Jokikokko et al. 2004; Jonsson et al. 1990; Jutila et al. 2003; Miettinen et al. 2021; Niemelä et al. 2006a, b; Quinn et al. 2006; Shearer 1990). Therefore, fishing of individuals returning early in the season may lead to relative over-harvesting of females and later maturing salmon (Erkinaro et al. 2019; Niemelä et al. 2006a). As return migration timing appears to be a highly heritable trait (Stewart et al. 2002), such exploitation may contribute to long-term declines in the abundance of large adult salmon that usually enter rivers early in the season (Quinn et al. 2006). For example, it has been suggested that in some rivers prohibiting fishing in the early season may favor the spawning of multi-sea winter salmon and lead to their proportional increase in the stock (Kallio-Nyberg et al. 2011) and this is being implemented in some systems (Anonymous 2018; Jokikokko and Jutila 2005). Because of these aspects, temporal regulation of fisheries is a valuable tool for protecting maturation-related diversity of salmon stocks.

\section{Restocking}

Supplementing natural populations of Atlantic salmon through hatchery restocking programs in a manner that retains biodiversity is challenging (Fraser 2008). Retaining diversity in maturation timing is no exception. Supplementing natural populations of Atlantic salmon through hatchery restocking programs requires thoughtful consideration of maturation. For exploited fish populations to recover from undesired consequences of fishing pressure or other causes of population decline, it is essential that fishing selection has not eroded population genetic variability in traits such as age at maturity and size (Hard et al., 2008). Knowledge of the vgll3 locus (Ayllon et al. 2015; Barson et al. 2015) may be used to promote diversity in wild salmon populations and hatchery broodstocks for restocking purposes. Here, targeted assays can rapidly and cost-effectively genotype the genomic region containing the vgll3 locus in large numbers of fish (Bernatchez et al. 2017; Czorlich et al. 2018). These genotypes may predict the age when stocked adults return to fresh water to spawn, and be used to control the frequency of the late maturation allele in parr and/or smolts that are released into the wild. This approach could help guide breeding programs to produce late maturing individuals of salmon and possibly other exploited fish species if they exhibit similar shifts in the timing of maturation. However, this strategy has the potential to backfire if the environmental conditions selecting against large, late maturing, individuals are not well understood (Kostow 2004). In addition, populations in captive breeding programs may rapidly lose genetic diversity and fitness (reviewed in Fraser 2008). Thus, caution is warranted in applying "gene-targeted" conservation and management planning (Kardos and Shafer 2018; Pearse 2016) by selective breeding and reintroductions of late maturing fish into wild populations.

\section{Recreational angling}

Maturation affects size and abundance of Atlantic salmon and the presence of prized large salmon is essential to recreational fisheries to attract anglers (Anderson and Lee 2013; Beardmore et al. 2015). Across the species distribution, recreational fishing is of great economic importance (Myrvold et al. 2019). A number of country- and river-specific economic assessments support the high economic value of recreational fisheries (e.g., Butler et al. 2009; Gardner 2011; Pohja-Mykrä et al. 2018; Pokki et al. 2018). In total, anglers of wild salmon across the North Atlantic were estimated to spend 300-500 million euros in 2017 in expenditures related to angling (Myrvold et al. 2019).

The decrease in the frequency of late maturing, large Atlantic salmon in many populations (Chaput 2012) likely impacts recreational fisheries. First, larger adults produce more offspring (Fleming 1998; Mobley et al. 2019, 2020) and are therefore important 
for the long-term viability and sustainability of natural salmon populations. Second, the opportunity to catch large salmon is an important draw for recreational fishers, such as tourist anglers who typically prefer larger fish (Anderson and Lee 2013; Beardmore et al. 2015). Because selective harvesting can influence trends in body size and migration timing (Quinn et al. 2006), it is important to carefully consider the sex and age at maturity of salmon harvested by recreational anglers when developing management regulations. The substantial economic benefits provided by regional recreational fisheries may also affect the optimal design of commercial fishing strategies, fishing allocation policies, and international fisheries management of Atlantic salmon stocks on a larger scale (Oinonen et al. 2017). Taken together, efforts to maintain and increase the attractiveness of Atlantic salmon to recreational anglers should take into account variation in age at maturity when selecting optimal fishing strategies and conservation measures aiming to maximize the economic benefits of different fisheries.

\section{Aquaculture}

Similar to wild Atlantic salmon populations, aquaculture strains face a trade-off between growth and maturation. However, early maturation in aquaculture is problematic because it decreases size and flesh quality (reviewed in Good and Davidson 2016; Taranger et al. 2010) and represents a large economic loss for the industry (Johnston et al. 2006; McClure et al. 2007). When farmed salmon become sexually mature, their growth rate decreases (Gjerde 1984). This growth decrease occurs because energy stores are primarily used for sexual development (Hendry et al. 1999) and feed consumption is reduced (Kadri et al. 1996) in the period leading up to maturation. For these reasons, fish farms harvest at the onset of maturation (Aksnes et al. 1986; Taranger and Hansen 1993). In aquaculture, timing of maturation is controlled by manipulating environmental parameters such as photoperiod and temperature (Bromage et al. 2001; King and Pankhurst 2007; Mohamed et al. 2019; Pankhurst and Porter 2003). However, these manipulations only partially reduce the problem of early maturation (Taranger et al. 2010) with significant financial losses due to maturation related factors being reported (McClure et al. 2007; Stead et al. 1999). Domesticated salmon strains exhibited a 3-5 fold decrease in parr maturation probability compared to a wild stock (Debes and Hutchings 2014), suggesting that there is potential for further reduction in this trait via selection, which could potentially be fast-tracked using markerassisted selection based on the maturation-associated loci described earlier in this synthesis.

\section{Future outlook}

Our current understanding of maturation in Atlantic salmon has gained a new perspective due to recent breakthroughs in comprehending the ecological conditions, genetic-based traits, and molecular and physiological processes underlying maturation. Looking toward the future, we provide an overview of research areas that we view as important next steps for maturation research.

Understanding how previous life-history stages affect maturation: the value of technological advances in longitudinal studies

In section Maturation in life history stages, we noted that maturation is a continuous process and that developmental processes initiated during embryonic development may influence maturation. However, we have only fragmented knowledge of how genetics and ecological factors related to specific developmental stages affect maturation during later stages, how these processes interact and/or accumulate during maturation, and how these processes ultimately affect fitness. Progress to date is thanks, in large part, to the ability to monitor maturation of the same individuals at different points in their life-history. For example, longitudinal studies using traditional approaches including common garden studies (Debes et al. 2020; O'Toole et al. 2015; Skaala et al. 2019), tagging (Chaput et al. 2018; Thorpe et al. 1981), inferring life history strategies via scale readings (e.g., Erkinaro et al. 2019; Mobley et al. 2020), or a combination of several of these (Norrgård et al. 2014) have illuminated patterns of maturation in a variety of ecologically relevant settings.

Currently, trade-offs related to the specific methodological approaches limit possibilities to generalize, and often result in a focus on interactions between a limited number of life history stages. For example, common garden studies allow environmental 
manipulation, but the environment is generally not reflective of what would be experienced in the wild. Tagging experiments are prone to low sample sizes in later life-history phases due to poor survival and these, but also studies utilizing scale-inferred life-history information, generally have limited scope regarding the specific environmental conditions individuals have experienced, particularly in the poorly understood marine phase.

We view recent and future technological advances in longitudinal studies as playing a pivotal role in linking maturation between different life history stages at the individual level. For example, although cost and size remains prohibitive for use in large numbers and at all life-history stages, satellite tags hold great potential to provide individual-level information about location and environmental conditions in the future (e.g., Strøm et al. 2018). Advances in stable isotope composition analysis can provide more detailed insights into long distance migrations without the need for tagging (Matsubayashi et al. 2020), while decreasing costs for genetic tagging offer opportunities for improving sample sizes via "close-kin markrecapture" (Bravington et al. 2016). Finally, eDNA techniques may be used to determine kinship, sex ratios, population size, and density, although its application for longitudinal studies at the individual level is unclear based on current practices (Adams et al. 2019; Spear et al. 2020). In the future, studies that incorporate such technological advances should help to reveal how genetic and environmental factors influence maturation over an individual's lifetime.

Ecological factors affecting maturation: linking life history phases and reproductive fitness

The majority of studies that experimentally test how ecological factors affect maturation have focused on the freshwater phase (Table 1). This is mostly due to practical reasons associated with capturing, rearing, and tracking individuals. Juveniles can be electrofished from streams in high abundance compared to seafaring post-smolts and adults, embryos and parr are much smaller than their post-smolt counterparts and thus do not require as extensive facilities for rearing and monitoring, and mature male parr can be reared within one year. Such studies have provided a wealth of information on the ecological factors affecting maturation during early life stages.
However, knowledge gaps remain concerning later life history stages. For example, gaining a better understanding of ecological factors affecting the less understood female maturation process is particularly important since reproduction is ultimately dependent upon female fecundity (Fleming 1996, 1998; Heinimaa and Heinimaa 2004). A second limitation of the focus on pre-marine migration maturation is that other critical maturation time points, such as the ecological factors that affect maturation during the marine phase, are not well understood.

In the marine phase, factors influencing maturation timing and return migration are partially genetically determined, yet growth and diet still play a role. A better understanding of maturation triggers at sea remain partially obscured by the difficulty of tracking individuals on their return migration from feeding grounds. This could be overcome by combining longterm climate and prey species data along with monitoring of salmon at sea with genetic and diet studies at different times of the year. For example, focusing on the return migrating salmon during the summer and fall may help to understand the physiological changes linked with maturation during these periods.

How maturation at different life history stages influences fitness is not well understood. This can be solved by long-term pedigree studies, breeding experiments and modeling approaches aimed at understanding the ecological factors and underlying genetics of reproductive fitness (e.g., McGinnity et al. 2003; Mobley et al. 2020; O'Sullivan et al. 2019). For example, noting the strong effect of incubation temperature on the growth and timing of the return migration, how incubation temperature affects the reproduction and survivorship of the F1 generation is still unknown. This could be important for adaptation in the face of climate change.

There are also new opportunities for understanding ecological factors linked with maturation thanks to the recent advances in understanding the genetic basis of maturation strategies. Large-effect maturation loci, such as $v g l l 3$, can be used as 'markers' of the likely future life history strategy of individuals already during the earliest developmental stages. Thus integrating genetic information with ecological data may help to disentangle differences in maturation strategies during different life history stages. 
Genetics of maturation: functional validation of genes associated with maturation

Functional validation of genes in candidate regions associated with maturation is a logical next step to confirm their role in Atlantic salmon maturation. Validation should include in vitro (cell line), in vivo (tissue, whole organism) and in silico (computational modelling) studies during different developmental life history stages to further our understanding of the roles of these genes. Some achievements have already been accomplished, for example, in functional studies of vgll3, akapl1 and six6 (Kjærner-Semb et al. 2018; Kurko et al. 2020; Moustakas-Verho et al. 2020; Verta et al. 2020), but more research is required to fully understand the molecular roles of these genes, as well as genes they interact with, in the maturation process.

Further research on gene expression at both transcriptional (mRNA) and translational (protein) level, as well as on epigenetic modifications, will be necessary to determine the potentially complex molecular pathways that candidate genes with different genotypes take part in, ultimately leading to phenotypic variation directly in maturation or maturation-related processes. Molecular functions of target genes can be studied in a detailed manner at the cellular level by examining, for example, mRNA expression by single-cell qPCR and RNAseq or cellular location of mRNA and protein using in situ hybridization and antigen labelling techniques, respectively. Further, techniques to study proteinprotein interactions can reveal novel information on potential binding partners of candidate genes. In the case of vgll3 and six6 encoding transcription factors, chromatin immunoprecipitation assay (ChIP-Seq) would provide relevant knowledge about the transcriptional targets of these proteins. Additionally, reporter assays enabling studying promoter activity could shed light on whether noncoding regions with SNPs associated with sea age [e.g., the noncoding region between vgll3 and akap 11, (Barson et al. 2015)] are regulatory and whether genetic variation in these regions affects regulation of the target gene expression.

An exciting new way to study the functional importance of candidate genes is to use genome editing techniques. CRISPR-Cas9 technology is being increasingly used to knock-out or edit genes, whereas RNA interference (RNAi) can be used to knock down expression at the organismal or cellular level to examine the effect on the phenotype and downstream molecular pathways. The CRISPR-Cas 9 technique has already been successfully implemented in Atlantic salmon (Datsomor et al. 2019). Gene editing by the CRISPR-Cas9 system would allow for converting a certain genotype to another. For example, modifying a vgll3 EE genotype into an $L L$ genotype and vice-versa in a fertilized egg would demonstrate if an artificial vgll3 genotype has the same influence on phenotypic variation as a natural vgll3 genotype. Provided appropriate experimental and ethical safeguards are in place, experiments such as this would allow a deeper understanding of the regulatory pathways controlling maturation.

Maturation candidate genes identified via QTL and genetic studies differ across studies. Determining the reasons why these differences are observed is key for understanding the genetic architecture of Atlantic salmon maturation. Lack of power in some studies may have given rise to such differences. However, it remains unknown whether these differences could instead be a result of differences in the effect of these genes among populations or lineages. Future work on identifying candidate genes should aim to survey a wide range of populations representing all lineages of Atlantic salmon. Additionally, examining populationspecific gene-by-environment effects may help to elucidate whether differences in gene effects may occur due to differences in life history traits and ecological factors experienced in different populations. Furthermore, sex-dependent dominance at the vgll3 was observed in European wild populations (Barson et al. 2015), but no dominance pattern was observed in males from a Norwegian aquaculture strain (Sinclair-Waters et al. 2020). This raises the question whether sex-dependent dominance at the vgll3 locus exists in all populations and if there are specific conditions in the wild that give rise to this dominance effect (e.g. limited food availability). Lastly, future work should investigate whether sexspecific maturation gene effects exist.

Molecular and physiological mechanisms of maturation: incorporating a greater diversity of life history stages and molecular approaches

Beyond the functional validation of genes associated with maturation is the need for a systemic approach 
that integrates molecular and physiological communication across the organism. The function of each part of the BPG axis is well known with regards to maturation and its timing in salmonids. Still obscure is the causality between activation of the BPG axis and initiation of the maturation process, and whether interindividual variation in the elements of the BPG axis can explain variation in maturation.

Currently, it is unclear how genetic variation in life history genomic regions interacts with the BPG axis, though it is likely that six6 is involved in neuronal development and hormonal regulation of this axis, as suggested by its expression in Atlantic salmon (Kurko et al. 2020; Moustakas-Verho et al. 2020). Genetic variation in six6 (Barson et al. 2015; Sinclair-Waters et al. 2020) and other genomic regions may explain differences in the timing of BPG axis activation, and, therefore, maturation. The molecular role of six 6 and the link between its genetic variation and functional outcome in the BPG axis should be examined in more detail in salmon. Future studies need to address the evolution of the BPG axis in populations with known genetic backgrounds and maturation status.

How ecological factors, such as changes in photoperiod, temperature, salinity, interspecific competition, and diet, affect gene expression, hormonal regulation, and lipid metabolism have been extensively studied with respect to maturation. Future research would benefit not only from the addition of genetic background information and population structure, but also from more extensive application of "big data" approaches such as metabolomics and lipidomics (broad-scale analyses of hundreds or thousands of metabolites and lipid species, respectively) to provide a broader profile of the molecules involved in the maturation process as well as their associations and interactions.

Climate change and other anthropogenic issues affecting maturation: can salmon adapt?

Given the close relationship of salmon maturation with several environmental factors including temperature, it is no surprise that range-wide rapid decline in salmon stocks has been linked to global climate change (Lehnert et al. 2019; Mills et al. 2013). In particular, declines of large, later maturing individuals of up to $88 \%$ have been observed in regions across the Atlantic salmon range (Chaput 2012). How well
Atlantic salmon can adapt to a changing climate may be limited, in part, by the species' evolutionary response to selection (Radchuk et al. 2019). Therefore, a major goal of future research should be to investigate how predicted increases in temperature will affect the timing of maturation, reproductive fitness of different life history strategies, and the long-term persistence of natural salmon populations (Cline et al. 2019; Hedger et al. 2013; Sundt-Hansen et al. 2018). This will require better knowledge of how temperature at different stages of life history (e.g., freshwater $v s$. marine phases) influences maturation trajectories, as well as how temperature interacts with genetic factors (Debes et al. 2020).

Climate change can also be expected to have a number of indirect effects of significance for salmon maturation. For example, altered climatic conditions in the marine environment, either directly due to temperature increase, or altered oceanic current patterns, may affect the abundance and distribution of key prey species of salmon (Todd et al. 2008). This can have knock-on effects altering growth and adiposity, and thereby, maturation. Such changes can be predicted to affect alternative life history strategies differently. For example, the negative effects of reduced marine prey abundance may be greater for individuals spending multiple years at sea before reproduction (Czorlich et al. 2018). In the event of reduced rainfall, decreased river flow can decrease oxygen saturation levels, which in turn can affect metabolism, feeding rates, and growth rates (Hosfeld et al. 2008) thereby affecting maturation. Decreased water flow can also decrease the ability of large, latematuring, individuals to reach spawning areas that were previously accessible in higher flow conditions.

Besides climate change, a variety of pernicious anthropogenic threats may influence salmon maturation in unpredictable ways. Pollution from industrial waste and pharmaceuticals, particularly those that alter behavior (Klaminder et al. 2019) or interfere with normal hormonal regulation such as endocrine disrupting compounds, may alter development and maturation (Björnsson et al. 2011; Duffy et al. 2014; McCormick et al. 2005). More generally, any anthropogenic factor that can affect growth or survival has the potential to alter maturation trajectories of individuals. 
Fishing and aquaculture: potential benefits of utilizing recent discoveries

The long-term success of fisheries is highly dependent on the potential of fish stocks to adapt to changing environments. However, how salmon respond to selection has rarely been considered in fishing policies (Hard et al. 2008). This may change in the future as we gain a better understanding of the ecological and genetic factors influencing maturation in Atlantic salmon (Barson et al. 2015; Czorlich et al. 2018; Sinclair-Waters et al. 2020).

Knowledge of the genetic control of the timing of maturation is critical for understanding and predicting the evolutionary impact of fishing (Kuparinen and Hutchings 2017; Kuparinen and Merilä 2007). Monitoring population allele frequency changes over time on known maturation genes will help to elucidate how maturation timing may change under different kinds of harvesting pressure. For instance, the timing and locality of fishing, and gear used, may select for individuals with differing maturation strategies. Current models predicting the effects of fishing on maturation have considered a polygenic genetic architecture (i.e., many small-effect genes) and a single large-effect locus without sexual selection (Kuparinen and Hutchings 2017). Future models should aim to incorporate knowledge of estimated effect sizes for known candidate genes. Additionally, one should consider how linkage disequilibrium patterns within the genome may modify the effects that fishing has on maturation (see Oomen et al. 2020). Thus, integrating new information of maturation genes will help inform management strategies aimed at maintaining variability in the timing of maturation in salmon populations.

Knowledge of maturation genes has potential value for selection aimed at optimizing the timing of maturation in aquaculture strains. For example, new genetic knowledge could help reduce the frequency of mature male parr via marker-assisted selection, and thus decrease the amount of resources and individuals with undesirable maturation strategies. In addition, understanding how maturation is genetically correlated with other traits can help define limits of artificial selection on the timing of maturation.

\section{Conclusions and recommendations}

The ever-increasing research on Atlantic salmon maturation consolidates the species as a tractable vertebrate model system for studying various aspects of maturation (Chakradhar 2018). Our goal for this synthesis is to provide a current overview of research on maturation in Atlantic salmon with the express purpose to identify major themes where information is lacking and thus highlight potential areas for future research. Here, we proffer our major conclusions and recommendations for the field as it moves forward.

1. Maturation occurs throughout the life cycle, starting from embryonic development and throughout each distinct life history stage. However, our knowledge of maturation during some life history stages is incomplete. For example, ecological investigations mostly focus on freshwater life-history stages, whereas less is known about maturation in the marine phase. In contrast, few genomic studies investigating maturationrelated traits have been conducted on early embryonic and juvenile phenotypic traits of importance during the freshwater phase. Moreover, gene expression studies overwhelmingly focus on maturation in male parr, whereas much less is known concerning gene expression patterns prior to the return migration and in maturing females. Finally, we still lack basic knowledge concerning how ecological and genetic factors influence embryonic development. Future research should address these gaps in our knowledge in order to identify critical developmental time points and life history phases that are key to maturation in this species.

2. Variation in the timing of maturation promotes diversity in life history strategies. We now have an understanding that the timing of maturation during different life history phases drives the exceptionally high life history diversity within this species. However, many questions remain. For example, what is the genetic architecture of male parr maturation and iteroparity? How does development in one life history phase affect maturation in later stages? What are the relative fitnesses of different life history strategies in different environments? A combination of common garden experiments, wild pedigrees, longitudinal studies, 
and modeling approaches may help to answer these questions in the future.

3. Ecological and genetic factors influence maturation. A range of ecological factors, most notably temperature and photoperiod, affect maturation at different life history stages while several genetic factors including large-effect loci influence maturation during the marine phase. However, research on these factors is not yet sufficiently integrated. For example, although there is considerable knowledge of i) how ecological factors influence maturation and ii) the molecular processes of maturation, our understanding of how i) affects ii) and vice versa is more limited. Studies that combine ecological and molecular approaches, e.g., common garden experiments, may help to disentangle the relative contributions of each of these factors to the maturation process.

4. Maturation processes are sex-specific and may have fitness consequences for each sex. Males and females mature at different ages and have different physiological and metabolic requirements for reproduction. These differences in the timing of maturation between the sexes may start as early as embryonic development and drive intra-locus sexual conflict at large-effect loci related to maturation. Moreover, the maintenance of alternative mating strategies and the relative contribution of male mature parr to reproductive fitness is not well understood in nature. Future studies investigating differences between the sexes in traits and gene expression patterns and how these differences translate into reproductive fitness during different life stages and alternative reproductive strategies will help to illuminate sexspecific maturation processes.

5. Molecular and physiological maturation pathways are affected by large-effect loci. Maturation during the marine phase is affected by large-effect loci suggesting a relatively simple genetic architecture, yet the details of how this is achieved are not well understood. Future research should take advantage of this simplified genetic architecture to identify the causal genes within the identified large-effect genomic regions associated with maturation and identify the role(s) of these genes using functional validation techniques.

6. The brain-pituitary-gonadal axis is a central player that regulates molecular and physiological processes of maturation in Atlantic salmon. While we are beginning to unravel the intricacies of the BPG axis, it is unclear how variation in largeeffect loci controlling maturation processes and ecological factors interacts with the BPG axis. In addition, how downstream physiological and metabolic processes, such as lipid metabolism and storage, are regulated by the BPG axis in salmon are not well understood. Future research should focus on feedback between external ecological factors, the genetic architecture, and the internal physiological processes to better understand how maturation occurs at the molecular level.

7. Knowledge of maturation is a key component of conservation and management programs in many populations and stocks. Variation in maturation timing has positive consequences for population genetic diversity. Therefore the preservation of phenotypic variation linked with maturation should increase the adaptive potential of populations. Moreover, genetic markers linked to largeeffect maturation loci offer new avenues to further develop management and conservation tools for preserving variation in life history strategies.

8. Climate change, fishing pressure, and other anthropogenic stressors likely have major effects on salmon maturation. Due to their direct and indirect effects on growth and survival, various anthropogenic factors have been shown to have significant effects on maturation trajectories. Such knowledge can improve predictions concerning how populations may respond to different harvest regimes or fishing restrictions. However, considering the combined effects of harvesting and other anthropogenic factors on life-history diversity, as well as incorporating knowledge of maturation trait genetic architecture into forecasts, has rarely been achieved. This would be an ambitious, yet worthy, goal for future population management.

Acknowledgements We would like to thank Cano Arias for salmon images and Jaakko Erkinaro and the Natural Resources Institute Finland (Luke) for the scale image. We would also like to thank J. Hutchings, C. Bouchard, and three anonymous reviewers for their constructive comments on previous manuscript versions. The research group received funding from the European Research Council (ERC) under the European Union's Horizon 2020 research and innovation programme (Grant agreement No. 742312), from the Academy of Finland 
Grants 307593, 302873 and 284941 and from the University of Helsinki.

Author contributions K.B.M. initiated the review and all authors drafted the manuscript.

Funding Open access funding provided by University of Helsinki including Helsinki University Central Hospital.

\section{Declarations}

Conflict of interest The authors declare no conflict of interest.

Open Access This article is licensed under a Creative Commons Attribution 4.0 International License, which permits use, sharing, adaptation, distribution and reproduction in any medium or format, as long as you give appropriate credit to the original author(s) and the source, provide a link to the Creative Commons licence, and indicate if changes were made. The images or other third party material in this article are included in the article's Creative Commons licence, unless indicated otherwise in a credit line to the material. If material is not included in the article's Creative Commons licence and your intended use is not permitted by statutory regulation or exceeds the permitted use, you will need to obtain permission directly from the copyright holder. To view a copy of this licence, visit http://creativecommons.org/licenses/by/4.0/.

\section{References}

Adams CE, Thorpe JE (1989) Photoperiod and temperature effects on early development and reproductive investment in Atlantic salmon (Salmo salarSalmo salarL.). Aquaculture 79:403-409. https://doi.org/10.1016/00448486(89)90483-3

Adams CI, Knapp M, Gemmell NJ, Jeunen G-J, Bunce M, Lamare MD, Taylor HR (2019) Beyond biodiversity: can Environmental DNA (eDNA) cut it as a population genetics tool? Genes 10:192. https://doi.org/10.3390/ genes 10030192

Aksnes A, Gjerde B, Roald SO (1986) Biological, chemical and organoleptic changes during maturation of farmed Atlantic salmon. Salmo salar. Aquacult 53:7-20. https://doi.org/10. 1016/0044-8486(86)90295-4

Amano M, Urano A, Aida K (1997) Distribution and function of gonadotropin-releasing hormone $(\mathrm{GnRH})$ in the teleost brain. Zoolog Sci 14:1-11. https://doi.org/10.2108/zsj.14.1

Anderson LE, Lee ST (2013) Untangling the recreational value of wild and hatchery salmon. Mar Resour Econ 28:175-197. https://doi.org/10.5950/0738-1360-28.2.175

Anderson SC, Cooper AB, Dulvy NK (2013) Ecological prophets: quantifying metapopulation portfolio effects. Methods Ecol Evol 4:971-981. https://doi.org/10.1111/ 2041-210X.12093

Andersson E et al (2013) Pituitary gonadotropin and ovarian gonadotropin receptor transcript levels: seasonal and photoperiod-induced changes in the reproductive physiology of female Atlantic salmon (Salmo salar). Gen Comp
Endocrinol 191:247-258. https://doi.org/10.1016/j.ygcen. 2013.07.001

Anonymous (2018) Status of the Tana/Teno River salmon populations in 2017. Report from the Tana Monitoring and Research Group nr 1/2018. https://www.luke.fi/wpcontent/uploads/2018/03/Tana-status-report-1-2018-final. pdf

Antonopoulou E, Borg B (2016) The brain-pituitary-gonad axis in the Atlantic salmon. In: Petersson E (ed) Vladić TV Evolutionary biology of the Atlantic Salmon. CRC Press, Boca Raton, pp 108-123

Armstrong JD, McKelvey S, Smith GW, Rycroft P, Fryer RJ (2018) Effects of individual variation in length, condition and run-time on return rates of wild-reared Atlantic salmon Salmo salar smolts. J Fish Biol 92:569-578. https://doi. org/10.1111/jfb.13548

Aubin-Horth N, Dodson JJ (2004) Influence of individual body size and variable thresholds on the incidence of a sneaker male reproductive tactic in Atlantic salmon. Evolution 58:136-144. https://doi.org/10.1111/j.0014-3820.2004. tb01580.x

Aubin-Horth N, Landry CR, Letcher BH, Hofmann HA (2005) Alternative life histories shape brain gene expression profiles in males of the same population. Proc Biol Sci 272:1655-1662. https://doi.org/10.1098/rspb.2005.3125

Aubin-Horth N, Letcher BH, Hofmann HA (2009) Gene-expression signatures of Atlantic salmon's plastic life cycle. Gen Comp Endocrinol 163:278-284. https://doi.org/10. 1016/j.ygcen.2009.04.021

Auld HL, Noakes DLG, Banks MA (2019) Advancing mate choice studies in salmonids. Rev Fish Biol Fish. https://doi. org/10.1007/s11160-019-09551-5

Aykanat $\mathrm{T}$ et al (2020) Life history genomic regions explain differences in Atlantic salmon marine diet specialization. J Anim Ecol 89:2677-2691. https://doi.org/10.1111/13652656.13324

Aykanat T, Ozerov M, Vähä J-P, Orell P, Niemelä E, Erkinaro J, Primmer CR (2019) Co-inheritance of sea age at maturity and iteroparity in the Atlantic salmon vgll3 genomic region. J Evol Biol 32:343-355. https://doi.org/10.1111/ jeb. 13418

Ayllon F et al (2015) The vgll3 locus controls age at maturity in wild and domesticated Atlantic salmon (Salmo salar L.) males. PLOS Genet 11:e1005628. https://doi.org/10.1371/ journal.pgen.1005628

Ayllon F et al (2019) The influence of vgll3 genotypes on sea age at maturity is altered in farmed mowi strain Atlantic salmon. BMC Genet 20:44-44. https://doi.org/10.1186/ s12863-019-0745-9

Bacles CFE, Bouchard C, Lange F, Manicki A, Tentelier C, Lepais O (2018) Estimating the effective number of breeders from single parr samples for conservation monitoring of wild populations of Atlantic salmon Salmo salar. J Fish Biol 92:699-726. https://doi.org/10.1111/jfb.13537

Bacon PJ, Malcolm IA, Fryer RJ, Glover RS, Millar CP, Youngson AF (2015) Can conservation stocking enhance juvenile emigrant production in wild Atlantic salmon? Trans Am Fish Soc 144:642-654. https://doi.org/10.1080/ 00028487.2015.1017655

Bagliniere JL, Maisse G (1985) Precocious maturation and smoltification in wild Atlantic salmon in the Armorican 
massif. France Aquacult 45:249-263. https://doi.org/10. 1016/0044-8486(85)90274-1

Balment RJ, Lu W, Weybourne E, Warne JM (2006) Arginine vasotocin a key hormone in fish physiology and behaviour: a review with insights from mammalian models. Gen Comp Endocrinol 147:9-16. https://doi.org/10.1016/j. ygcen.2005.12.022

Barson NJ et al (2015) Sex-dependent dominance at a single locus maintains variation in age at maturity in salmon. Nature 528:405. https://doi.org/10.1038/nature16062

Baum D, Laughton R, Armstrong JD, Metcalfe NB (2005) The effect of temperature on growth and early maturation in a wild population of Atlantic salmon parr. J Fish Biol 67:1370-1380. https://doi.org/10.1111/j.0022-1112.2005. 00832.x

Baynes SM, Scott AP (1985) Seasonal variations in parameters of milt production and in plasma concentration of sex steroids of male rainbow trout (Salmo gairdneri). Gen Comp Endocrinol 57:150-160. https://doi.org/10.1016/ 0016-6480(85)90211-4

Beardmore B, Hunt LM, Haider W, Dorow M, Arlinghaus R (2015) Effectively managing angler satisfaction in recreational fisheries requires understanding the fish species and the anglers. Can J Fish Aquat Sci 72:500-513. https://doi. org/10.1139/cjfas-2014-0177

Benedet S, Bjornsson BT, Taranger GL, Andersson E (2008) Cloning of somatolactin alpha, beta forms and the somatolactin receptor in Atlantic salmon: seasonal expression profile in pituitary and ovary of maturing female broodstock. Reprod Biol Endocrinol RB\&E 6:42. https://doi.org/ 10.1186/1477-7827-6-42

Benedet S, Andersson E, Mittelholzer C, Taranger GL, Bjornsson BT (2010) Pituitary and plasma growth hormone dynamics during sexual maturation of female Atlantic salmon. Gen Comp Endocrinol 167:77-85. https://doi.org/ 10.1016/j.ygcen.2010.02.011

Bentley JW, Serpetti N, Heymans JJ (2017) Investigating the potential impacts of ocean warming on the Norwegian and Barents Seas ecosystem using a time-dynamic food-web model. Ecol Model 360:94-107. https://doi.org/10.1016/j. ecolmodel.2017.07.002

Bernardo J (1993) Determinants of maturation in animals. Trends Ecol Evol 8:166-173. https://doi.org/10.1016/ 0169-5347(93)90142-C

Bernatchez L et al (2017) Harnessing the power of genomics to secure the future of seafood. Trends Ecol Evol 32:665-680. https://doi.org/10.1016/j.tree.2017.06.010

Björnsson BT, Stefansson SO, McCormick SD (2011) Environmental endocrinology of salmon smoltification. Gen Comp Endocrinol 170:290-298. https://doi.org/10.1016/j. ygcen.2010.07.003

Boulding EG, Ang KP, Elliott JAK, Powell F, Schaeffer LR (2019) Differences in genetic architecture between continents at a major locus previously associated with sea age at sexual maturity in European Atlantic salmon. Aquaculture 500:670-678. https://doi.org/10.1016/j.aquaculture.2018. 09.025

Brännäs E (1995) First access to territorial space and exposure to strong predation pressure: A conflict in early emerging Atlantic salmon (Salmo salar L.) fry. Evol Ecol 9:411-420. https://doi.org/10.1007/BF01237763
Bravington MV, Grewe PM, Davies CR (2016) Absolute abundance of southern bluefin tuna estimated by close-kin mark-recapture. Nat Commun 7:13162. https://doi.org/10. 1038/ncomms 13162

Breton B, Govoroun M, Mikolajczyk T (1998) GTH I and GTH II secretion profiles during the reproductive cycle in female rainbow trout: relationship with pituitary responsiveness to GnRH-A stimulation. Gen Comp Endocrinol 111:38-50. https://doi.org/10.1006/gcen.1998.7088

Bromage N, Porter M, Randall C (2001) The environmental regulation of maturation in farmed finfish with special reference to the role of photoperiod and melatonin. Aquaculture 197:63-98. https://doi.org/10.1016/S00448486(01)00583-X

Burgerhout E, Mommens M, Johnsen H, Aunsmo A, Santi N, Andersen $\varnothing$ (2017) Genetic background and embryonic temperature affect DNA methylation and expression of myogenin and muscle development in Atlantic salmon (Salmo salar). PLOS ONE 12:e0179918. https://doi.org/ 10.1371/journal.pone.0179918

Butler JRA, Radford A, Riddington G, Laughton R (2009) Evaluating an ecosystem service provided by Atlantic salmon, sea trout and other fish species in the River Spey, Scotland: the economic impact of recreational rod fisheries. Fish Res 96:259-266. https://doi.org/10.1016/j.fishres. 2008.12.006

COSEWIC (2010) COSEWIC assessment and status report on the Atlantic Salmon Salmo salar (Nunavik population, Labrador population, Northeast Newfoundland population, South Newfoundland population, Southwest Newfoundland population, Northwest Newfoundland population, Quebec Eastern North Shore population, Quebec Western North Shore population, Anticosti Island population, Inner St. Lawrence population, Lake Ontario population, GaspéSouthern Gulf of St. Lawrence population, Eastern Cape Breton population, Nova Scotia Southern Upland population, Inner Bay of Fundy population, Outer Bay of Fundy population) in Canada. Ottawa. Ottawa. pp xlvii - 136. https://www.canada.ca/en/environment-climate-change/ services/species-risk-publicregistry/cosewic-assessmentsstatus-reports/atlantic-salmon.html

Cánovas A et al (2014) Multi-tissue omics analyses reveal molecular regulatory networks for puberty in composite beef cattle. PLoS ONE 9:1-17. https://doi.org/10.1371/ journal.pone.0102551

Cauwelier E, Gilbey J, Sampayo J, Stradmeyer L, Middlemas SJ (2018) Identification of a single genomic region associated with seasonal river return timing in adult Scottish Atlantic salmon (Salmo salar) identified using a genome-wide association study. Canadian $\mathrm{J}$ Fish Aquatic Sci 75:1427-1435. https://doi.org/10.1139/cjfas-2017-0293

Celius T, Walther BT (1998) Oogenesis in Atlantic salmon (Salmo salar L.) occurs by zonagenesis preceding vitellogenesis in vivo and in vitro. J Endocrinol 158:259-266. https://doi.org/10.1677/joe.0.1580259

Chakradhar S (2018) Animals on the verge: What different species can teach us about human puberty. Nat Med 24:114-117. https://doi.org/10.1038/nm0218-114

Chaput G (2012) Overview of the status of Atlantic salmon (Salmo salar) in the North Atlantic and trends in marine 
mortality ICES. J Mar Sci 69:1538-1548. https://doi.org/ 10.1093/icesjms/fss013

Chaput G, Caron F, Marshall L (2003) Estimates of survival of Atlantic salmon (Salmo salar L.) in the first and second years at sea. In: Potter ECE, Ó Maoiléidigh N, Chaput G, editors. Marine mortality of Atlantic salmon, Salmo salar L: methods and measures. DFO Can Sci Advis Sec Res Doc 2003/101, pp 83-109

Chaput G, Dempson JB, Caron F, Jones R, Gibson J (2006) A synthesis of life history characteristics and stock grouping of Atlantic salmon (Salmo salar L.) in eastern Canada. DFO Can Sci Advis Sec Res Doc 2006/015, p 53

Chaput G, Carr J, Daniels J, Tinker S, Jonsen I, Whoriskey F (2018) Atlantic salmon (Salmo salar) smolt and early postsmolt migration and survival inferred from multi-year and multi-stock acoustic telemetry studies in the Gulf of St Lawrence, northwest Atlantic ICES. J Mar Sci 76:1107-1121. https://doi.org/10.1093/icesjms/fsy156\% JICESJournalofMarineScience

Chi L, Li X, Liu Q, Liu Y (2017) Photoperiod regulate gonad development via kisspeptin/kissr in hypothalamus and saccus vasculosus of Atlantic salmon (Salmo salar). PLOS ONE 12:e0169569. https://doi.org/10.1371/journal.pone. 0169569

Chi L, Li X, Liu Q, Liu Y (2019) Photoperiod may regulate growth via leptin receptor A1 in the hypothalamus and saccus vasculosus of Atlantic salmon (Salmo salar). Animal Cells Syst 23:200-208. https://doi.org/10.1080/ 19768354.2019.1595138

Choi YJ, Kim NN, Shin HS, Choi CY (2014) The expression of leptin, estrogen receptors, and vitellogenin mRNAs in migrating female Chum salmon, Oncorhynchus keta: the effects of hypo-osmotic environmental changes. AsianAustralasian J Animal Sci 27:479-487. https://doi.org/10. 5713/ajas.2013.13592

Chou MY, Hung JC, Wu LC, Hwang SP, Hwang PP (2011) Isotocin controls ion regulation through regulating ionocyte progenitor differentiation and proliferation. Cell Mol Life Sci 68:2797-2809. https://doi.org/10.1007/s00018010-0593-2

Christensen KA, Gutierrez AP, Lubieniecki KP, Davidson WS (2017) TEAD3, implicated by association to grilsing in Atlantic salmon. Aquaculture 479:571-578. https://doi. org/10.1016/j.aquaculture.2017.06.026

Ciani E et al (2020) Gnrh receptor gnrhr2bb $\alpha$ is expressed exclusively in lhb-expressing cells in Atlantic salmon male parr General and Comparative. Endocrinology 285:113293. https://doi.org/10.1016/j.ygcen.2019.113293

Cline TJ, Ohlberger J, Schindler DE (2019) Effects of warming climate and competition in the ocean for life-histories of Pacific salmon. Nat Ecol Evol 3:935-942. https://doi.org/ 10.1038/s41559-019-0901-7

Coggins LG, Catalano MJ, Allen MS, Pine WE, Walters CJ (2007) Effects of cryptic mortality and the hidden costs of using length limits in fishery management. Fish Fish 8:196-210. https://doi.org/10.1111/j.1467-2679.2007. 00247.x

Connallon T, Clark AG (2014) Balancing selection in species with separate sexes: insights from Fisher's geometric model. Genetics 197:991-1006. https://doi.org/10.1534/ genetics.114.165605
Conover DO, Arnott SA, Walsh MR, Munch SB (2005) Darwinian fishery science: lessons from the Atlantic silverside (Menidia menidia). Canadian J Fish Aquat Sci 62:730-737. https://doi.org/10.1139/f05-069

Consuegra S, De Leániz CG, Serdio A, Verspoor E (2005) Selective exploitation of early running fish may induce genetic and phenotypic changes in Atlantic salmon. J Fish Biol 67:129-145. https://doi.org/10.1111/j.0022-1112. 2005.00844.x

Cousminer DL et al (2013) Genome-wide association and longitudinal analyses reveal genetic loci linking pubertal height growth, pubertal timing and childhood adiposity. Human Mol Genet 22:2735-2747. https://doi.org/10.1093/ hmg/ddt 104

Crespo D et al (2019) The initiation of puberty in Atlantic salmon brings about large changes in testicular gene expression that are modulated by the energy status. BMC Genomics 20:475. https://doi.org/10.1186/s12864-0195869-9

Crisp DT, Carling PA (1989) Observations on siting, dimensions and structure of salmonid redds. J Fish Biol 34:119-134. https://doi.org/10.1111/j.1095-8649.1989. tb02962.x

Czorlich Y, Aykanat T, Erkinaro J, Orell P, Primmer CR (2018) Rapid sex-specific evolution of age at maturity is shaped by genetic architecture in Atlantic salmon. Nat Ecol Evol 2:1800-1807. https://doi.org/10.1038/s41559-018-0681-5

Czorlich Y, Aykanat T, Erkinaro J, Orell P, Primmer CR (2021) Evolution in salmon life-history induced by direct and indirect effects of fishing. https://doi.org/10.1101/2021.01. 08.425869

Damsgård B, Evensen Tor H, Øverli Ø, Gorissen M, Ebbesson Lars OE, Rey S, Höglund E (2019) Proactive avoidance behaviour and pace-of-life syndrome in Atlantic salmon . R Soc Open Sci 6:181859. https://doi.org/10.1098/rsos. 181859

Datsomor AK et al (2019) CRISPR/Cas9-mediated ablation of elovl2 in Atlantic salmon (Salmo salar L) inhibits elongation of polyunsaturated fatty acids and induces Srebp-1 and target genes. Sci Rep 9:7533. https://doi.org/10.1038/ s41598-019-43862-8

Daufresne M, Lengfellner K, Sommer U (2009) Global warming benefits the small in aquatic ecosystems. Proc Natl Acad Sci USA 106:12788-12793. https://doi.org/10.1073/pnas. 0902080106

Debes PV et al (2019) Large single-locus effects for maturation timing are mediated via body condition in Atlantic salmon. bioRxiv. https://doi.org/10.1101/780437

Debes PV, Hutchings JA (2014) Effects of domestication on parr maturity, growth, and vulnerability to predation in Atlantic salmon. Canadian J Fish Aquat Sci 71:1371-1384. https://doi.org/10.1139/cjfas-2013-0618

Debes PV, Plavchenko N, Erkinaro J, Primmer CR (2020) Genetic growth potential, rather than phenotypic size, predicts migration phenotype in Atlantic salmon. Proc R Soc B 287(2020):0867. https://doi.org/10.1098/rspb.2020. 0867

de Roos AM, Boukal DS, Persson L (2006) Evolutionary regime shifts in age and size at maturation of exploited fish stocks 273:1873-1880. https://doi.org/10.1098/rspb.2006.3518 
Dodson JJ, Aubin-Horth N, Thériault V, Páez DJ (2013) The evolutionary ecology of alternative migratory tactics in salmonid fishes. Biol Rev 88:602-625. https://doi.org/10. 1111/brv.12019

Duffy TA, Iwanowicz LR, McCormick SD (2014) Comparative responses to endocrine disrupting compounds in early life stages of Atlantic salmon. Salmo salar Aquat Toxicol 152:1-10. https://doi.org/10.1016/j.aquatox.2014.03.015

Duston J, Saunders RL (1997) Life histories of Atlantic salmon altered by winter temperature and summer rearing in freshor sea-water. Environ Biol Fishes 50:149-166. https://doi. org/10.1023/A:1007373016067

Duston J, Saunders RL (1999) Effect of winter food deprivation on growth and sexual maturity of Atlantic salmon (Salmo salar) in seawater. Canadian J FishAquat Sci 56:201-207. https://doi.org/10.1139/f98-165

Einum S (2003) Atlantic salmon growth in strongly food-limited environments: Effects of egg size and paternal phenotype? Environ Biol Fishes 67:263-268. https://doi.org/10.1023/ A: 1025818627731

Einum S, Fleming IA (2000) Highly fecund mothers sacrifice offspring survival to maximize fitness. Nature 405:565. https://doi.org/10.1038/35014600

Einum S, Thorstad EB, Næsje TF (2002) Growth rate correlations across life-stages in female Atlantic salmon. J Fish Biol 60:780-784. https://doi.org/10.1111/j.1095-8649. 2002.tb01704.x

Elks CE et al (2010) Thirty new loci for age at menarche identified by a meta-analysis of genome-wide association studies. Nat Genet 42:1077-1085. https://doi.org/10.1038/ ng.714

Elliott JM (1991) Tolerance and resistance to thermal stress in juvenile Atlantic salmon. Salmo salar Freshw Biol 25:61-70. https://doi.org/10.1111/j.1365-2427.1991. tb00473.x

Elliott JM, Elliott JA (2010) Temperature requirements of Atlantic salmon Salmo salar, brown trout Salmo trutta and Arctic charr Salvelinus alpinus: predicting the effects of climate change. J Fish Biol 77:1793-1817. https://doi.org/ 10.1111/j.1095-8649.2010.02762.x

Ellis BJ (2013) The hypothalamic-pituitary-gonadal axis: A switch-controlled, condition-sensitive system in the regulation of life history strategies. Hormones Behav 64:215-225. https://doi.org/10.1016/j.yhbeh.2013.02.012

Erkinaro J et al (2019) Life history variation across four decades in a diverse population complex of Atlantic salmon in a large subarctic river. Can J Fish Aquat Sci 76:42-55. https://doi.org/10.1139/cjfas-2017-0343

Erkinaro J, Dempson JB, Julkunen M, Niemelä E (1997) Importance of ontogenetic habitat shifts to juvenile output and life history of Atlantic salmon in a large subarctic river: an approach based on analysis of scale characteristics. J Fish Biol 51:1174-1185. https://doi.org/10.1111/j.10958649.1997.tb01134.x

Figeac N et al. (2019) VGLL3 operates via TEAD1, TEAD3 and TEAD4 to influence myogenesis in skeletal muscle. J Cell Sci 132:jcs225946. https://doi.org/10.1242/jcs.225946

Finstad AG, Jonsson B (2012) Effect of incubation temperature on growth performance in Atlantic salmon. Mar Ecol Progress Ser 454:75-82. https://doi.org/10.3354/ meps09643
Finstad AG, Armstrong JD, Nislow KH (2011) Freshwater habitat requirements of Atlantic salmon. In: Aas $\varnothing$, Einum S, Klemetsen A, Skurdal J (eds) Atlantic Salmon Ecology. 1st edn. Blackwell Publishing Ltd., Hoboken, NJ, pp 67-87. https://doi.org/10.1002/9781444327755.ch3

Fitzpatrick MS, Van der Kraak G, Schreck CB (1986) Profiles of plasma sex steroids and gonadotropin in coho salmon, Oncorhynchus kisutch, during final maturation. Gen Comp Endocrinol 62:437-451. https://doi.org/10.1016/00166480(86)90054-7

Fjelldal PG, Hansen T, Huang T-S (2011) Continuous light and elevated temperature can trigger maturation both during and immediately after smoltification in male Atlantic salmon (Salmo salar). Aquaculture 321:93-100. https://doi. org/10.1016/j.aquaculture.2011.08.017

Fjelldal PG, Schulz R, Nilsen TO, Andersson E, Norberg B, Hansen TJ (2018) Sexual maturation and smoltification in domesticated Atlantic salmon (Salmo salar L.) - is there a developmental conflict? Physiol Rep 6:e13809-e13809. https://doi.org/10.14814/phy2.13809

Fleming IA (1996) Reproductive strategies of Atlantic salmon: ecology and evolution. Rev Fish Biol Fisheries 6:379-416. https://doi.org/10.1007/BF00164323

Fleming IA (1998) Pattern and variability in the breeding system of Atlantic salmon (Salmo salar), with comparisons to other salmonids. Canadian J Fish Aquat Sci 55:59-76. https://doi.org/10.1139/d98-009

Fleming IA, Einum S (2011) Reproductive ecology: a tale of two sexes. In: Aas $\varnothing$, Einum S, Klemetsen A, Skurdal J (eds) Atlantic Salmon Ecology. Wiley, pp 33-65. https:// doi.org/10.1002/9781444327755.ch2

Fleming IA, Gross MR (1994) Breeding competition in a Pacific salmon (Coho: Oncorhynchus kisutch): measures of natural and sexual selection. Evolution 48:637-657. https://doi. org/10.2307/2410475

Fleming IA, Reynolds JD (2004) Salmonid breeding systems. In: Hendry AP, Stearns SC (eds) Evolution illuminated: salmon and their relatives. Oxford University Press Inc., New York. 264-294

Fleming IA, Jonsson B, Gross MR, Lamberg A (1996) An experimental study of the reproductive behaviour and success of farmed and wild Atlantic salmon (Salmo salar). J Appl Ecol 33:893-905. https://doi.org/10.2307/2404960

Foote CJ, Brown GS, Wood CC (1997) Spawning success of males using alternative mating tactics in sockeye salmon, Oncorhynchus nerka. Canadian J Fish Aquat Sci 54:1785-1795. https://doi.org/10.1139/f97-080

França LR, Nóbrega RH, Morais RDVS, De Castro Assis LH, Schulz RW (2015) 13-Sertoli cell structure and function in anamniote vertebrates. In: Griswold MD (ed) Sertoli Cell Biology (Second Edition). Academic Press, Oxford, pp 385-407. https://doi.org/10.1016/B978-0-12-417047-6. 00013-2

Fraser DJ (2008) How well can captive breeding programs conserve biodiversity? A review of salmonids. Evol Appl 1:535-586. https://doi.org/10.1111/j.1752-4571.2008. 00036.x

Fraser TWK, Fjelldal PG, Schulz RW, Norberg B, Hansen TJ (2019) Termination of puberty in out-of-season male Atlantic salmon smolts. Comp BiochemPhysiol Part A Mol Integr Physiol. https://doi.org/10.1016/j.cbpa.2019.03.011 
Friedland K, Haas RE (1996) Marine post-smolt growth and age at maturity of Atlantic salmon. J Fish Biol 48:1-15. https:// doi.org/10.1111/j.1095-8649.1996.tb01414.x

Friedland KD, Hansen LP, Dunkley DA, MacLean JC (2000) Linkage between ocean climate, post-smolt growth, and survival of Atlantic salmon (Salmo salar L.) in the North Sea area. ICES Journal of Marine Science 57:419-429. https://doi.org/10.1006/jmsc.1999.0639

Friedland KD, Reddin DG, Castonguay M (2003) Ocean thermal conditions in the post-smolt nursery of North American Atlantic salmon. ICES J Mar Sci 60:343-355. https:// doi.org/10.1016/S1054-3139(03)00022-5

Friedland KD, Chaput G, MacLean JC (2005) The emerging role of climate in post-smolt growth of Atlantic salmon. ICES J Mar Sci 62:1338-1349. https://doi.org/10.1016/j. icejms.2005.04.013

Friedland KD, Moore D, Hogan F (2009) Retrospective growth analysis of Atlantic salmon (Salmo salar) from the Miramichi River Canada. Canadian J Fish Aquat Sci 66:1294-1308. https://doi.org/10.1139/f09-077

Gage MJG, Stockley P, Parker GA (1995) Effects of alternative male mating strategies on characteristics of sperm production in the Atlantic salmon (Salmo salar): Theoretical and empirical investigations. Philos Trans R Soc London Ser B Biol Sci 350:391-399. https://doi.org/10.1098/rstb. 1995.0173

Gage MJG, Macfarlane CP, Yeates S, Ward RG, Searle JB, Parker GA (2004) Spermatozoal traits and sperm competition in Atlantic salmon: relative sperm velocity is the primary determinant of fertilization success. Curr Biol 14:44-47. https://doi.org/10.1016/j.cub.2003.12.028

Gaggiotti OE, Vetter RD (1999) Effect of life history strategy, environmental variability, and overexploitation on the genetic diversity of pelagic fish populations. Canadian J Fish Aquat Sci 56:1376-1388. https://doi.org/10.1139/f99060

Garant D, Fontaine P-M, Good SP, Dodson JJ, Bernatchez L (2002) The influence of male parental identity on growth and survival of offspring in Atlantic salmon (Salmo salar). Evol Ecol Res 4:537-549

Garcia de Leaniz C et al (2007) A critical review of adaptive genetic variation in Atlantic salmon: implications for conservation. Biol Rev 82:173-211. https://doi.org/10. 1111/j.1469-185X.2006.00004.X

Gardner Pinfold Consultants Inc. (2011) Economic value of wild Atlantic salmon. Report for the Atlantic Salmon Federation. pp 1-82. https://www.asf.ca/assets/files/ gardner-pinfold-value-wild-salmon.pdf

Gibson RJ (1993) The Atlantic salmon in fresh water: spawning, rearing and production. Rev Fish Biol Fish 3:39-73. https://doi.org/10.1007/BF00043297

Gibson RJH, Williams DD, McGowan C, Davidson WS (1996) The ecology of dwarf fluvial Atlantic salmon, Salmo salar L., cohabiting with brook trout, Salvelinus fontinalis [Mitchill], in Southeastern Newfoundland. Canada. Pol Arch Hydrobiol 43:145-166

Gielen JT, Goos HJ, Peute J, van den Bosch RA, van Oordt PG (1982) The brain-pituitary-gonadal axis in the rainbow trout, Salmo gairdneri: gonadal hormones and the maturation of gonadotropic cells. Cell Tissue Res 225:45-56. https://doi.org/10.1007/bf00216217
Gilbey J, McLay A, Houlihan D, Verspoor E (2005) Individuallevel analysis of pre- and post first-feed growth and development in Atlantic salmon. J Fish Biol 67:1359-1369. https://doi.org/10.1111/j.0022-1112.2005. 00831. $\mathrm{x}$

Gjerde B (1984) Response to individual selection for age at sexual maturity in Atlantic salmon. Aquaculture 38:229-240. https://doi.org/10.1016/00448486(84)90147-9

Godwin J, Thompson R (2012) Nonapeptides and social behavior in fishes. Horm Behav 61:230-238. https://doi. org/10.1016/j.yhbeh.2011.12.016

Gomez JM, Weil C, Ollitrault M, Le Bail PY, Breton B, Le Gac F (1999) Growth hormone (GH) and gonadotropin subunit gene expression and pituitary and plasma changes during spermatogenesis and oogenesis in rainbow trout $(\mathrm{On}$ corhynchus mykiss). Gen Comp Endocrinol 113:413-428. https://doi.org/10.1006/gcen.1998.7222

Good C, Davidson J (2016) A review of factors influencing maturation of Atlantic salmon Salmo salar, with focus on water recirculation aquaculture system environments. J World Aquacult Soc 47:605-632. https://doi.org/10. 1111/jwas. 12342

Gorodilov YN (1996) Description of the early ontogeny of the Atlantic salmon, Salmo salar, with a novel system of interval (state) identification. Environ Biol Fish 47:109-127. https://doi.org/10.1007/BF00005034

Gorodilov YN (2010) The biological clock in vertebrate embryogenesis as a mechanism of general control over the developmental organism. Russ J Dev Biol 41:201-216. https://doi.org/10.1134/s1062360410040016

Gregory SD, Armstrong JD, Britton JR (2018) Is bigger really better? Towards improved models for testing how Atlantic salmon Salmo salar smolt size affects marine survival. J Fish Biol 92:579-592. https://doi.org/10.1111/jfb.13550

Grimardias D, Merchermek N, Manicki A, Garnier J, Gaudin P, Jarry M, Beall E (2010) Reproductive success of Atlantic salmon (Salmo salar) mature male parr in a small river, the Nivelle: influence of shelters. Ecol Freshw Fish 19:510-519. https://doi.org/10.1111/j.1600-0633.2010. 00421.x

Gross MR (1996) Alternative reproductive strategies and tactics: Diversity within sexes. Trends Ecol Evol 11:92-98

Guiry A et al (2010) Testes and brain gene expression in precocious male and adult maturing Atlantic salmon (Salmo salar). BMC Genomics 11:211. https://doi.org/10.1186/ 1471-2164-11-211

Gutierrez AP, Lubieniecki KP, Fukui S, Withler RE, Swift B, Davidson WS (2014) Detection of quantitative trait loci (QTL) related to grilsing and late sexual maturation in Atlantic salmon (Salmo salar). Mar Biotechnol 16:103-110. https://doi.org/10.1007/s10126-013-9530-3

Gutierrez AP, Yá JM, Fukui S, Swift B, Davidson WS (2015) Genome-Wide Association Study (GWAS) for growth rate and age at sexual maturation in Atlantic salmon (Salmo salar). PLoS ONE 10:1-15. https://doi.org/10.1371/ journal.pone.0119730

Halder G, Johnson RL (2011) Hippo signaling: growth control and beyond Development 138:9-22. https://doi.org/10. 1242/dev.045500 
Halperin DS, Pan C, Lusis AJ, Tontonoz P (2013) Vestigial-like 3 is an inhibitor of adipocyte differentiation. J Lipid Res 54:473-481. https://doi.org/10.1194/jlr.m032755

Hamor T, Garside ET (1976) Developmental rates of embryos of Atlantic salmon, Salmo salar L., in response to various levels of temperature, dissolved oxygen, and water exchange, Canadian. J Zool 54:1912-1917. https://doi.org/ 10.1139/z76-221

Handeland SO, Imsland AK, Stefansson SO (2008) The effect of temperature and fish size on growth, feed intake, food conversion efficiency and stomach evacuation rate of Atlantic salmon post-smolts. Aquaculture 283:36-42. https://doi.org/10.1016/j.aquaculture.2008.06.042

Hansen LP, Jonsson B, Morgan RIG, Thorpe JE (1989) Influence of parr maturity on emigration of smolting Atlantic salmon (Salmo salar). Canadian J FishAquat Sci 46:410-415. https://doi.org/10.1139/f89-054

Hansen T, Stefansson S, Taranger GL (1992) Growth and sexual maturation in Atlantic salmon, Salmo, salar L., reared in sea cages at two different light regimes. Aquacult Fish Manag 23:275-280. https://doi.org/10.1111/j.1365-2109. 1992.tb00770.x

Hard JJ, Gross MR, Heino M, Hilborn R, Kope RG, Law R, Reynolds JD (2008) SYNTHESIS: Evolutionary consequences of fishing and their implications for salmon. Evol Appl 1:388-408. https://doi.org/10.1111/j.1752-4571. 2008.00020.x

Harvey AC, Tang Y, Wennevik V, Skaala Ø, Glover KA (2017) Timing is everything: Fishing-season placement may represent the most important angling-induced evolutionary pressure on Atlantic salmon populations. Ecol Evol 7:7490-7502. https://doi.org/10.1002/ece3.3304

Healy K, Ezard THG, Jones OR, Salguero-Gómez R, Buckley YM (2019) Animal life history is shaped by the pace of life and the distribution of age-specific mortality and reproduction. Nat Ecol Evol. https://doi.org/10.1038/s41559019-0938-7

Hedger RD, Sundt-Hansen LE, Forseth T, Ugedal O, Diserud OH, Kvambekk ÅS, Finstad AG (2013) Predicting climate change effects on subarctic-Arctic populations of Atlantic salmon (Salmo salar). Canadian J Fish Aquat Sci 70:159-168. https://doi.org/10.1139/cjfas-2012-0205

Heggberget TG (1988) Timing of spawning in Norwegian Atlantic salmon (Salmo salar). Canadian J Fish Aquat Sci 45:845-849

Heinimaa S, Erkinaro J (2004) Characteristics of mature male parr in the northernmost Atlantic salmon populations. J Fish Biol 64:219-226. https://doi.org/10.1111/j.10958649.2004.00308.x

Heinimaa S, Heinimaa P (2004) Effect of the female size on egg quality and fecundity of the wild Atlantic salmon in the sub-arctic River Teno. Boreal Environ Res 9:55-62

Hendry AP, Berg OK, Quinn TP (1999) Condition dependence and adaptation-by-time: breeding date, life history, and energy allocation within a population of salmon. Oikos 85:499-514. https://doi.org/10.2307/3546699

Hendry AP, Castric V, Kinnison MT, Quinn TP (2003) The evolution of philopatry and dispersal: homing versus straying in salmonids. In: Sterns SC (ed) Hendry AP. Salmon and Their Relatives. Oxford University Press, Evolution Illuminated, pp 53-91
Herbinger CM, Friars GW (1992) Effects of winter temperature and feeding regime on the rate of early maturation in Atlantic salmon (Salmo salar) male parr. Aquaculture 101:147-162. https://doi.org/10.1016/00448486(92)90239-H

He JX, Stewart DJ (2001) Age and size at first reproduction of fishes: preditive models based only on growth trajectories. Ecology 82:784-791. https://doi.org/10.1890/00129658(2001)082[0784:AASAFR]2.0.CO;2

Hosfeld CD et al (2008) Long-term separate and combined effects of environmental hypercapnia and hyperoxia in Atlantic salmon (Salmo salar L.) smolts. Aquaculture 280:146-153. https://doi.org/10.1016/j.aquaculture.2008. 05.009

Houde ALS, Fraser DJ, O'Reilly P, Hutchings JA (2010) Maternal and paternal effects on fitness correlates in outbred and inbred Atlantic salmon (Salmo salar). Canadian J Fish Aquat Sci 68:534-549. https://doi.org/10.1139/f2011001

Houston RD, Macqueen DJ (2019) Atlantic salmon (Salmo salar L.) genetics in the 21st century: taking leaps forward in aquaculture and biological understanding. Anim Genet 50:3-14. https://doi.org/10.1111/age.12748

Hutchings JA (2011) Old wine in new bottles: reaction norms in salmonid fishes. Heredity 106:421-437. https://doi.org/10. 1038/hdy.2010.166

Hutchings JA et al (2019) Life-history variability and conservation status of landlocked Atlantic salmon: an overview. Can J Fish Aquat Sci 76:1697-1708. https://doi.org/10. 1139/cjfas-2018-0413

Hutchings JA, Jones MEB (1998) Life history variation and growth rate thresholds for maturity in Atlantic salmon Salmo salar. Canadian J Fish Aquat Sci 55:22-47. https:// doi.org/10.1139/d98-004

Hutchings JA, Morris DW (1985) The influence of phylogeny, size and behaviour on patterns of covariation in salmonid life histories. Oikos 45:118-124. https://doi.org/10.2307/ 3565229

Hutchings JA, Myers RA (1994) The evolution of alternative mating strategies in variable environments. Evol Ecol 8:256-268. https://doi.org/10.1007/bf01238277

Hvidsten NA et al (2009) Influence of sea temperature and initial marine feeding on survival of Atlantic salmon Salmo salar post-smolts from the Rivers Orkla and Hals. Norway J Fish Biol 74:1532-1548. https://doi.org/10.1111/j.1095-8649. 2009.02219.x

Idler DR, Bitners II, Schmidt PJ (1961) 11-ketotestosterone: an androgen for sockeye salmon. Canadian J Biochem Physiol 39:1737-1742

Imsland AK, Handeland SO, Stefansson SO (2014) Photoperiod and temperature effects on growth and maturation of preand post-smolt Atlantic salmon. Aquacult Int 22:1331-1345. https://doi.org/10.1007/s10499-014-97501

Jacobsen JA, Hansen LP (2001) Feeding habits of wild and escaped farmed Atlantic salmon, Salmo salar L., in the northeast Atlantic Ices. J Mar Sci 58:916-933. https://doi. org/10.1006/jmsc.2001.1084

Jenkins LE, Pierce AL, Graham ND, Medeiros LR, Hatch DR, Nagler JJ (2019) Elevated plasma triglycerides and growth rate are early indicators of reproductive status in post- 
spawning female steelhead trout (Oncorhynchus mykiss). Conserv Physiol. https://doi.org/10.1093/conphys/coz038

Johnston IA et al (2006) Muscle and flesh quality traits in wild and farmed Atlantic salmon. Aquaculture 256:323-336. https://doi.org/10.1016/j.aquaculture.2006.02.048

Johnston SE et al (2013) Fish scales and SNP chips: SNP genotyping and allele frequency estimation in individual and pooled DNA from historical samples of Atlantic salmon (Salmo salar). BMC Genomics 14:439. https://doi. org/10.1186/1471-2164-14-439

Johnston SE et al (2014) Genome-wide SNP analysis reveals a genetic basis for sea-age variation in a wild population of Atlantic salmon (Salmo salar). Mol Ecol 23:3452-3468. https://doi.org/10.1111/mec.12832

Jokikokko E, Jutila E (2005) Effect of fishing regulation on the occurrence of repeat spawners and age distribution of Atlantic salmon in a northern Baltic river. Fish Manage Ecol 12:341-347. https://doi.org/10.1111/j.1365-2400. 2005.00457.x

Jokikokko E, Kallio-Nyberg I, Jutila E (2004) The timing, sex and age composition of the wild and reared Atlantic salmon ascending the Simojoki River, northern Finland. J Appl Ichthyol 20:37-42. https://doi.org/10.1111/j.1439-0426. 2004.00491.x

Jones MW, Hutchings JA (2002) Individual variation in Atlantic salmon fertilization success: implications for effective population size. Ecol Appl 12:184-193. https://doi.org/10. 2307/3061145

Jonsson B, Jonsson N (1993) Partial migration: niche shift versus sexual maturation in fishes. Rev Fish Biol Fisheries 3:348-365. https://doi.org/10.1007/BF00043384

Jonsson N, Jonsson B (2003) Energy allocation among developmental stages, age groups, and types of Atlantic salmon (Salmo salar) spawners. Canadian J Fish Aquat Sci 60:506-516. https://doi.org/10.1139/F03-042

Jonsson N, Jonsson B (2007) Sea growth, smolt age and age at sexual maturation in Atlantic salmon. J Fish Biol 71:245-252. https://doi.org/10.1111/j.1095-8649.2007. 01488.x

Jonsson B, Jonsson N (2011) Ecology of Atlantic Salmon and Brown Trout: Habitat as a Template for Life Histories. Springer, London. https://doi.org/10.1007/978-94-0071189-1

Jonsson B, Jonsson N (2014) Early environment influences later performance in fishes. J Fish Biol 85:151-188. https://doi. org/10.1111/jfb. 12432

Jonsson B, Jonsson N (2016) Trans-generational maternal effect: temperature influences egg size of the offspring in Atlantic salmon Salmo salar. J Fish Biol 89:1482-1487. https://doi.org/10.1111/jfb.13040

Jonsson B, Jonsson N (2018) Egg incubation temperature affects the timing of the Atlantic salmon Salmo salar homing migration. J Fish Biol 93:1016-1020. https://doi.org/10. 1111/jfb.13817

Jonsson N, Jonsson B, Hansen LP (1990) Partial segregation in the timing of migration of Atlantic salmon of different ages. Anim Behav 40:313-321. https://doi.org/10.1016/ S0003-3472(05)80926-1

Jonsson N, Hansen LP, Jonsson B (1991) Variation in age, size and repeat spawning of adult Atlantic salmon in relation to river discharge. J Animal Ecol 60:937-947. https://doi.org/ $10.2307 / 5423$

Jonsson N, Jonsson B, Hansen LP (1997) Changes in proximate composition and estimates of energetic costs during upstream migration and spawning in Atlantic salmon Salmo salar. J Anim Ecol 66:425-436. https://doi.org/10. 2307/5987

Jonsson B, Finstad AG, Jonsson N (2012) Winter temperature and food quality affect age at maturity: an experimental test with Atlantic salmon (Salmo salar). Canadian J Fish Aquat Sci 69:1817-1826. https://doi.org/10.1139/f2012-108

Jonsson B, Jonsson N, Finstad AG (2013) Effects of temperature and food quality on age and size at maturity in ectotherms: An experimental test with Atlantic salmon. J Anim Ecol 82:201-210. https://doi.org/10.1111/j.1365-2656.2012. 02022.x

Jonsson B, Jonsson N, Finstad AG (2014) Linking embryonic temperature with adult reproductive investment in Atlantic salmon Salmo salar. Mar Ecol Prog Ser 515:217-226. https://doi.org/10.3354/meps11006

Juanes F, Perez J, Garcia-Vazquez E (2007) Reproductive strategies in small populations: using Atlantic salmon as a case study. Ecol Freshw Fish 16:468-475. https://doi.org/ 10.1111/j.1600-0633.2007.00224.x

Julien HP, Bergeron NE (2006) Effect of fine sediment infiltration during the incubation period on Atlantic salmon (Salmo salar) embryo survival. Hydrobiologia 563:61-71. https://doi.org/10.1007/s10750-005-1035-2

Jutila E, Jokikokko E, Julkunen M (2003) Management of Atlantic salmon in the Simojoki river, northern Gulf of Bothnia: effects of stocking and fishing regulation. Fish Res 64:5-17. https://doi.org/10.1016/s01657836(03)00107-3

Kadri S, Mitchell DF, Metcalfe NB, Huntingford FA, Thorpe JE (1996) Differential patterns of feeding and resource accumulation in maturing and immature Atlantic salmon. Salmo salar Aquaculture 142:245-257. https://doi.org/10. 1016/0044-8486(96)01258-6

Kallio-Nyberg I, Saloniemi I, Jutila E, Jokikokko E (2011) Effect of hatchery rearing and environmental factors on the survival, growth and migration of Atlantic salmon in the Baltic Sea. Fish Res 109:285-294. https://doi.org/10.1016/ j.fishres.2011.02.015

Kardos M, Shafer ABA (2018) The peril of gene-targeted conservation. Trends Ecol Evol 33:827-839. https://doi.org/ 10.1016/j.tree.2018.08.011

Kasper C et al (2017) Genetics and developmental biology of cooperation. Mol Ecol 26:4364-4377. https://doi.org/10. 1111/mec. 14208

Kawauchi H (2006) Functions of melanin-concentrating hormone in fish J Exp Zool A Comp. Exp Biol 305:751-760. https://doi.org/10.1002/jez.a.310

Kazakov RV (1981) The effect of the size of Atlantic salmon, Salmo salar L., eggs on embryos and alevins. J Fish Biol 19:353-360. https://doi.org/10.1111/j.1095-8649.1981. tb05838.x

Keenleyside MHA, Yamamoto F, T. (1962) Territorial behaviour of juvenile Atlantic salmon (Salmo salar L.) Behaviour 19:139-169. http://www.jstor.org/stable/4533008

King HR, Pankhurst NW (2007) Additive effects of advanced temperature and photoperiod regimes and LHRHa 
injection on ovulation in Atlantic salmon (Salmo salar). Aquaculture 273:729-738. https://doi.org/10.1016/j. aquaculture.2007.07.008

Kjærner-Semb E et al. (2018) Vgll3 and the Hippo pathway are regulated in Sertoli cells upon entry and during puberty in Atlantic salmon testis, Sci Rep 8:1912. https://doi.org/10. 1038/s41598-018-20308-1

Klaminder J, Jonsson M, Leander J, Fahlman J, Brodin T, Fick J, Hellström G (2019) Less anxious salmon smolt become easy prey during downstream migration. Sci Total Environ 687:488-493. https://doi.org/10.1016/j.scitotenv.2019.05. 488

Kleppe L, Edvardsen RB, Furmanek T, Andersson E, Skaftnesmo KO, Thyri Segafredo F, Wargelius A (2020) Transcriptomic analysis of dead end knockout testis reveals germ cell and gonadal somatic factors in Atlantic salmon. BMC Genomics 21:99. https://doi.org/10.1186/s12864020-6513-4

Koskela J, Pirhonen J, Jobling M (1997) Effect of low temperature on feed intake, growth rate and body composition of juvenile Baltic salmon. Aquacult Int 5:479-488. https:// doi.org/10.1023/A:1018397014684

Kostow KE (2004) Differences in juvenile phenotypes and survival between hatchery stocks and a natural population provide evidence for modified selection due to captive breeding. Can J Fish Aquat Sci 61:577-589. https://doi. org/10.1139/f04-019

Kudo H, Kimura T, Hasegawa Y, Abe T, Ichimura M, Ijiri S (2018) Involvement of 11-ketotestosterone in hooknose formation in male pink salmon (Oncorhynchus gorbuscha) jaws. Gen Comp Endocrinol 260:41-50. https://doi.org/10. 1016/j.ygcen.2018.02.009

Kuparinen A, Hutchings JA (2017) Genetic architecture of age at maturity can generate divergent and disruptive harvestinduced evolution. Philos Trans R Soc B Biol Sci. https:// doi.org/10.1098/rstb.2016.0035

Kuparinen A, Hutchings JA (2019) When phenotypes fail to illuminate underlying genetic processes in fish and fisheries science. ICES J Mar Sci. https://doi.org/10.1093/icesjms/ fsz002

Kuparinen A, Merilä J (2007) Detecting and managing fisheriesinduced evolution. Trends Ecol Evol 22:652-659. https:// doi.org/10.1016/j.tree.2007.08.011

Kurko J, Debes PV, House A, Aykanat T, Erkinaro J, Primmer CR (2020) Transcription profiles of age-at-maturity-associated genes suggest cell fate commitment regulation as a key factor in the Atlantic salmon maturation process G3: Genes. Genomes Genetics 10:235-246. https://doi.org/10. 1534/g3.119.400882

Kusche H, Côté G, Hernandez C, Normandeau E, BoivinDelisle D, Bernatchez L (2017) Characterization of natural variation in North American Atlantic Salmon populations (Salmonidae: Salmo salar) at a locus with a major effect on sea age. Ecol Evol 7:5797-5807. https://doi.org/10.1002/ ece 3.3132

Laan M, Richmond H, He C, Campbell RK (2002) Zebrafish as a model for vertebrate reproduction: characterization of the first functional zebrafish (Danio rerio) gonadotropin receptor. General Comp Endocrinol 125:349-364. https:// doi.org/10.1006/gcen.2001.7738
Lam ME, Borch T (2011) Cultural valuing of fishery resources by the Norwegian Saami. Global Ecol Integr Sci Int Law. https://doi.org/10.5848/CSP.2833.00020

Larder R, Clark DD, Miller NL, Mellon PL (2011) Hypothalamic dysregulation and infertility in mice lacking the homeodomain protein Six6. J Neurosci 31:426-438. https://doi.org/10.1523/JNEUROSCI.1688-10.2011

Le Gac F, Loir M (1988) Control of testis function in fish: in vitro studies of gonadotropic regulation in the trout (Salmo gairdneri). Reprod Nutr Develop 28:1031-1046

Le Gac F, Blaise O, Fostier A, Le Bail PY, Loir M, Mourot B, Weil C (1993) Growth hormone (GH) and reproduction: a review. Fish Physiol Biochem 11:219-232. https://doi.org/ 10.1007/bf00004569

Lehnert SJ et al (2019) Genomic signatures and correlates of widespread population declines in salmon. Nat Commun 10:2996. https://doi.org/10.1038/s41467-019-10972-w

Lemaître J-F, Gaillard J-M (2017) Reproductive senescence: new perspectives in the wild. Biol Rev 92:2182-2199. https://doi.org/10.1111/brv.12328

Lepais O, Manicki A, Glise S, Buoro M, Bardonnet A (2017) Genetic architecture of threshold reaction norms for male alternative reproductive tactics in Atlantic salmon (Salmo salar L.). Sci Rep 7:43552-43552. https://doi.org/10.1038/ srep43552

Letcher BH, Gries G, Juanes F (2002) Survival of streamdwelling Atlantic salmon: effects of life history variation, season, and age. Trans Am Fish Soc 131:838-854. https:// doi.org/10.1577/1548-8659(2002)131<0838:SOSDAS $>2$. $0 . \mathrm{CO} ; 2$

Lien $\mathrm{S}$ et al (2016) The Atlantic salmon genome provides insights into rediploidization. Nature 533:200. https://doi. org/10.1038/nature17164

Lubzens E, Young G, Bobe J, Cerdà J (2010) Oogenesis in teleosts: How fish eggs are formed. Gen Comp Endocrinol 165:367-389. https://doi.org/10.1016/j.ygcen.2009.05.022

Luckenbach JA, Iliev DB, Goetz FW, Swanson P (2008) Identification of differentially expressed ovarian genes during primary and early secondary oocyte growth in coho salmon Oncorhynchus kisutch. Reprod Biol Endocrinol 6:2. https://doi.org/10.1186/1477-7827-6-2

Macqueen DJ et al (2017) Functional Annotation of All Salmonid Genomes (FAASG): an international initiative supporting future salmonid research, conservation and aquaculture. BMC Genomics 18:484. https://doi.org/10. 1186/s12864-017-3862-8

Mank JE (2017) Population genetics of sexual conflict in the genomic era. Nat Rev Genet 18:721. https://doi.org/10. 1038/nrg.2017.83

Martin JHA, Mitchell KA (1985) Influence of sea temperature upon the numbers of grilse and multi-sea-winter Atlantic salmon (Salmo salar) caught in the vicinty of the River Dee (Aberdeenshire). Canadian J Fish Aquat Sci 42:1513-1521. https://doi.org/10.1139/f85-189

Matsubayashi J et al (2020) Tracking long-distance migration of marine fishes using compound-specific stable isotope analysis of amino acids. Ecol Lett 23:881-890. https://doi. org/10.1111/ele.13496

Maugars G, Schmitz M (2008a) Expression of gonadotropin and gonadotropin receptor genes during early sexual 
maturation in male Atlantic salmon parr. Mol Reprod Dev 75:403-413. https://doi.org/10.1002/mrd.20767

Maugars G, Schmitz M (2008b) Gene expression profiling during spermatogenesis in early maturing male Atlantic salmon parr testes. Gen Comp Endocrinol 159:178-187. https://doi.org/10.1016/j.ygcen.2008.08.008

McClure CA, Hammell KL, Moore M, Dohoo IR, Burnley H (2007) Risk factors for early sexual maturation in Atlantic salmon in seawater farms in New Brunswick and Nova Scotia. Canada Aquacult 272:370-379. https://doi.org/10. 1016/j.aquaculture.2007.08.039

McCormick SD, Hansen LP, Quinn TP, Saunders RL (1998) Movement, migration, and smolting of Atlantic salmon (Salmo salar). Canadian J Fish Aquat Sci 55:77-92. https:// doi.org/10.1139/d98-011

McCormick SD, Shrimpton JM, Moriyama S, Björnsson BT (2002) Effects of an advanced temperature cycle on smolt development and endorinology indicate that temperature is not a zeitgeber for smolting in Atlantic salmon. J Exp Biol 205:3553-3560

McCormick SD, O'Dea MF, Moeckel AM, Lerner DT, Björnsson BT (2005) Endocrine disruption of parr-smolt transformation and seawater tolerance of Atlantic salmon by 4-nonylphenol and 17 $\beta$-estradiol. General Comp Endocrinol 142:280-288. https://doi.org/10.1016/j.ygcen. 2005.01.015

McCormick SD, Shrimpton JM, Moriyama S, Björnsson BT (2007) Differential hormonal responses of Atlantic salmon parr and smolt to increased daylength: A possible developmental basis for smolting. Aquaculture 273:337-344. https://doi.org/10.1016/j.aquaculture.2007.10.015

McCormick MI, Ryen CA, Munday PL, Walker SPW (2010) Differing mechanisms underlie sexual size-dimorphism in two populations of a sex-changing fish. Plos One. https:// doi.org/10.1371/journal.pone.0010616

McGinnity $\mathrm{P}$ et al (2003) Fitness reduction and potential extinction of wild populations of Atlantic salmon Salmo salar, as a result of interactions with escaped farm salmon. Proc R Soc London Ser B Biol Sci 270:2443-2450. https:// doi.org/10.1098/rspb.2003.2520

Melo MC et al (2015) Androgens directly stimulate spermatogonial differentiation in juvenile Atlantic salmon (Salmo salar). Gen Comp Endocrinol 211:52-61. https://doi.org/ 10.1016/j.ygcen.2014.11.015

Melo MC, Andersson E, Fjelldal PG, Bogerd J, Franca LR, Taranger GL, Schultz RW (2014) Salinity and photoperiod modulate pubertal development in Atlantic salmon (Salmo salar). J Endocrinol 220:319-332. https://doi.org/10.1530/ JOE-13-0240

Meng Z, Moroishi T, Guan KL (2016) Mechanisms of Hippo pathway regulation. Genes Dev 30:1-17. https://doi.org/ 10.1101/gad.274027.115

Metcalfe NB (1998) The interaction between behavior and physiology in determining life history patterns in Atlantic salmon (Salmo salar). Canadian J Fish Aquat Sci 55:93-103. https://doi.org/10.1139/d98-005

Metcalfe NB, Thorpe JE (1990) Determinants of geographical variation in the age of seaward-migrating salmon Salmo salar. J Animal Ecol 59:135-145. https://doi.org/10.2307/ 5163
Metcalfe NB, Thorpe JE (1992) Early predictors of life-history events: the link between first feeding date, dominance and seaward migration in Atlantic salmon Salmo salar L. J Fish Biol 41:93-99. https://doi.org/10.1111/j.1095-8649.1992. tb03871.x

Metcalfe NB, Valdimarsson SK, Fraser NHC (1997) Habitat profitability and choice in a sit-and-wait predator: juvenile salmon prefer slower currents on darker nights. J Anim Ecol 66:866-875. https://doi.org/10.2307/6002

Michielsens CGJ et al (2006) A Bayesian state-space markrecapture model to estimate exploitation rates in mixed stock fisheries. Canadian J Fish Aquat Sci 63:321-344. https://doi.org/10.1139/F05-215

Miettinen A et al. (2021) A large wild salmon stock shows genetic and life history differentiation within, but not between, rivers Conserv Genet 22:35-51. https://doi.org/ 10.1007/s10592-020-01317-y

Mills KE, Pershing AJ, Sheehan TF, Mountain D (2013) Climate and ecosystem linkages explain widespread declines in North American Atlantic salmon populations. Glob Change Biol 19:3046-3061. https://doi.org/10.1111/gcb. 12298

Miura T, Yamauchi K, Takahashi H, Nagahama Y (1992) The role of hormones in the acquisition of sperm motility in salmonid fish. J Exp Zool 261:359-363. https://doi.org/10. 1002/jez.1402610316

Miwa S, Yan L, Swanson P (1994) Localization of two gonadotropin receptors in the walmon gonad by in vitro ligand autoradiography. Biol Reprod 50:629-642. https://doi.org/ 10.1095/biolreprod50.3.629

Mjølnerod IB, Fleming IA, Refseth UH, Hindar K (1998) Mate and sperm competition during multiple-male spawnings of Atlantic salmon. Canadian J Zool Revue Can De Zoologie 76:70-75. https://doi.org/10.1139/z97-173

Mobley KB et al. (2019) Home ground advantage: local Atlantic salmon have higher reproductive fitness than dispersers in the wild. Sci Adv 5:eaav1112. https://doi.org/10.1126/ sciadv.aav1112

Mobley KB, Granroth-Wilding H, Ellmen M, Orell P, Erkinaro J, Primmer CR (2020) Time spent in distinct life-history stages has sex-specific effects on reproductive fitness in wild Atlantic salmon. Mol Ecol 29:1173-1184. https://doi. org $/ 10.1111 / \mathrm{mec} .15390$

Mohamed AR et al (2019) Polygenic and sex specific architecture for two maturation traits in farmed Atlantic salmon. BMC Genomics 20:139. https://doi.org/10.1186/s12864019-5525-4

Montserrat N, Gonzalez A, Mendez E, Piferrer F, Planas JV (2004) Effects of follicle stimulating hormone on estradiol17 beta production and P-450 aromatase (CYP19) activity and mRNA expression in brown trout vitellogenic ovarian follicles in vitro. Gen Comp Endocrinol 137:123-131. https://doi.org/10.1016/j.ygcen.2004.02.011

Moore A, Bendall B, Barry J, Waring C, Crooks N, Crooks L (2012) River temperature and adult anadromous Atlantic salmon, Salmo salar, and brown trout, Salmo trutta. Fish Manage Ecol 19:518-526. https://doi.org/10.1111/j.13652400.2011.00833.x

Morais RDVS et al (2017) Antagonistic regulation of spermatogonial differentiation in zebrafish (Danio rerio) by 
Igf3 and Amh. Mol Cell Endocrinol 454:112-124. https:// doi.org/10.1016/j.mce.2017.06.017

Morais RDVS, Nóbrega RH, Gómez-González NE, Schmidt R, Bogerd J, França LR, Schulz RW (2013) Thyroid hormone stimulates the proliferation of Sertoli cells and single type A spermatogonia in adult zebrafish (Danio rerio) testis. Endocrinology 154:4365-4376. https://doi.org/10.1210/ en.2013-1308

Moustakas-Verho JE, Kurko J, House AH, Erkinaro J, Debes P, Primmer CR (2020) Developmental expression patterns of six6: A gene linked with spawning ecotypes in Atlantic salmon. Gene Express Patterns 38:119149. https://doi.org/ 10.1016/j.gep.2020.119149

Myers RA (1984) Demographic consequences of precocious maturation of Atlantic salmon (Salmo salar). Canadian J Fish Aquat Sci 41:1349-1353. https://doi.org/10.1139/f84165

Myers RA, Hutchings JA, Gibson RJ (1986) Variation in male parr maturation within and among populations of Atlantic salmon Salmo salar. Canadian J Fish Aquat Sci 43:1242-1248. https://doi.org/10.1139/f86-154

Myrvold KM, Mawle GW, Andersen O, Aas Ø (2019) The Social, economic and cultural values of wild Atlantic salmon. A review of literature for the period 2009-2019 and an assessment of changes in values. Norwegian Institute for Nature Research. https://brage.nina.no/nina-xmlui/handle/ $11250 / 2627172$

Nagahama Y, Adachi S (1985) Identification of maturation-inducing steroid in a teleost, the amago salmon (Oncorhynchus rhodurus). Dev Biol 109:428-435. https://doi. org/10.1016/0012-1606(85)90469-5

Nagahama Y, Hirose K, Young G, Adachi S, Suzuki K, Tamaoki B (1983) Relative in vitro effectiveness of 17 alpha, 20 beta-dihydroxy-4-pregnen-3-one and other pregnene derivatives on germinal vesicle breakdown in oocytes of ayu (Plecoglossus altivelis), amago salmon (Oncorhynchus rhodurus), rainbow trout (Salmo gairdneri), and goldfish (Carassius auratus). Gen Comp Endocrinol 51:15-23. https://doi.org/10.1016/0016-6480(83)90092-8

Nakane Y et al (2013) The saccus vasculosus of fish is a sensor of seasonal changes in day length. Nat Communs 4:2108. https://doi.org/10.1038/ncomms3108

Nicieza AG, Braña F (1993) Relationships among smolt size, marine growth, and sea age at maturity of Atlantic salmon (Salmo salar) in northern Spain. Canadian J Fish Aquat Sci, 50:1632-1640. https://doi.org/10.1139/f93-184

Nielsen EE, Hansen MM (2008) Waking the dead: the value of population genetic analyses of historical samples. Fish Fish 9:450-461. https://doi.org/10.1111/j.1467-2979.2008. 00304.x

Niemelä E, Erkinaro J, Julkunen M, Hassinen E, Länsman M, Brørs S (2006a) Temporal variation in abundance, return rate and life histories of previously spawned Atlantic salmon in a large subarctic river. J Fish Biol, 68:1222-1240. https://doi.org/10.1111/j.0022-1112.2006.001012.x

Niemelä E, Orell P, Erkinaro J, Dempson JB, Br Ørs S, Svenning MA, Hassinen E (2006b) Previously spawned Atlantic salmon ascend a large subarctic river earlier than their maiden counterparts. J Fish Biol 69:1151-1163. https:// doi.org/10.1111/j.1095-8649.2006.01190.x
Nóbrega RH, Morais RDVdS, Crespo D, de Waal PP, de França LR, Schulz RW, Bogerd J (2015) Fsh stimulates spermatogonial proliferation and differentiation in zebrafish via Igf3. Endocrinology, 156:38043817. https://doi.org/10. 1210/en.2015-1157

Norrgård JR, Bergman E, Schmitz M, Greenberg LA (2014) Effects of feeding regimes and early maturation on migratory behaviour of landlocked hatchery-reared Atlantic salmon Salmo salar smolts. J Fish Biol 85:1060-1073. https://doi.org/10.1111/jfb.12522

Nozaki M et al (1990) Salmonid pituitary gonadotrophs. I Distinct cellular distributions of two gonadotropins, GTH I and GTH II. Gen Comp Endocrinol 77:348-357. https:// doi.org/10.1016/0016-6480(90)90224-a

O'Connell MF, Dempson JB, Chaput G (2006) Aspects of the life history, biology, and population dynamics of Atlantic salmon (Salmo salar L.) in eastern Canada. Canadian Sci Adv Secret Res Doc 2006/014, p 47

O'Sullivan RJ et al (2019) Evolutionary stasis of a heritable morphological trait in a wild fish population despite apparent directional selection. Ecol Evol 9:7096-7111. https://doi.org/10.1002/ece3.5274

Ohga H, Selvaraj S, Matsuyama M (2018) The Roles of kisspeptin system in the reproductive physiology of fish with special reference to chub mackerel studies as main axis. Front Endocrinol. https://doi.org/10.3389/fendo.2018. 00147

Oinonen S et al (2017) International fisheries management and recreational benefits: the case of Baltic salmon. Mar Resour Econ 31:433-433. https://doi.org/10.2307/ 44011981

Økland F, Jonsson B, Jensen AJ, Hansen LP (1993) Is there a threshold size regulating seaward migration of brown trout and Atlantic salmon? J Fish Biol 42:541-550. https://doi. org/10.1111/j.1095-8649.1993.tb00358.x

Oligny-Hébert H, Senay C, Enders EC, Boisclair D (2015) Effects of diel temperature fluctuation on the standard metabolic rate of juvenile Atlantic salmon (Salmo salar): influence of acclimation temperature and provenience. Canadian J Fish Aquat Sci, 72:1306-1315. https://doi.org/ 10.1139/cjfas-2014-0345

Olmos M, Massiot-Granier F, Prévost E, Chaput G, Bradbury IR, Nevoux M, Rivot E (2019) Evidence for spatial coherence in time trends of marine life history traits of Atlantic salmon in the North Atlantic. Fish Fish 20:322-342. https://doi.org/10.1111/faf.12345

Oomen RA, Kuparinen A, Hutchings JA (2020) Consequences of single-locus and tightly linked genomic architectures for evolutionary responses to environmental change. J Heredity esaa020. https://doi.org/10.1093/jhered/esaa020

Oppen-Berntsen DO, Gram-Jensen E, Walther BT (1992) Zona radiata proteins are synthesized by rainbow trout $(\mathrm{On}$ corhynchus mykiss) hepatocytes in response to oestradiol17 beta. J Endocrinol, 135:293-302. https://doi.org/10. 1677/joe.0.1350293

Oppen-Berntsen DO, Olsen SO, Rong CJ, Taranger GL, Swanson P, Walther BT (1994) Plasma levels of eggshell zr-proteins, estradiol-17 $\beta$, and gonadotropins during an annual reproductive cycle of Atlantic salmon (Salmo salar). J Exp Zool, 268:59-70. https://doi.org/10.1002/jez. 1402680108 
O'Toole CL et al (2015) The signature of fine scale local adaptation in Atlantic salmon revealed from common garden experiments in nature. Evol Appl 8:881-900. https://doi.org/10.1111/eva.12299

Páez DJ, Brisson-Bonenfant C, Rossignol O, Guderley HE, Bernatchez L, Dodson JJ (2011) Alternative developmental pathways and the propensity to migrate: a case study in the Atlantic salmon. J Evol Biol 24:245-255. https://doi. org/10.1111/j.1420-9101.2010.02159.x

Pakkasmaa S, Peuhkuri N, Laurila A, Hirvonen H, Ranta E (2001) Female and male contribution to egg size in salmonids. Evol Ecol 15:143-153. https://doi.org/10.1023/A: 1013873810905

Pankhurst NW, Porter MJR (2003) Cold and dark or warm and light: variations on the theme of environmental control of reproduction. Fish Physiol Biochem 28:385-389. https:// doi.org/10.1023/B:FISH.0000030602.51939.50

Parhar IS, Iwata M, Pfaff DW, Schwanzel-Fukuda M (1995) Embryonic development of gonadotropin-releasing hormone neurons in the sockeye salmon. J Comp Neurol 362:256-270. https://doi.org/10.1002/cne.903620208

Park H-K, Ahima RS (2015) Physiology of leptin: energy homeostasis, neuroendocrine function and metabolism Metabolism - Clinical and Experimental 64:24-34. https:// doi.org/10.1016/j.metabol.2014.08.004

Pearse DE (2016) Saving the spandrels? Adaptive genomic variation in conservation and fisheries management. J Fish Biol 89:2697-2716. https://doi.org/10.1111/jfb.13168

Pedersen S et al. (2013) Quantitative trait loci for precocious parr maturation, early smoltification, and adult maturation in double-backcrossed trans-Atlantic salmon (Salmo salar). Aquaculture, 410-411:164-171. https://doi.org/10. 1016/j.aquaculture.2013.06.039

Perrier C, Guyomard R, Bagliniere J-L, Nikolic N, Evanno G (2013) Changes in the genetic structure of Atlantic salmon populations over four decades reveal substantial impacts of stocking and potential resiliency. Ecol Evol 3:2334-2349. https://doi.org/10.1002/ece3.629

Perrier C, Normandeau É, Dionne M, Richard A, Bernatchez L (2014) Alternative reproductive tactics increase effective population size and decrease inbreeding in wild Atlantic salmon. Evol Appl 7:1094-1106. https://doi.org/10.1111/ eva. 12172

Perry JRB et al (2014) Parent-of-origin-specific allelic associations among 106 genomic loci for age at menarche. Nature, 514:92-97. https://doi.org/10.1038/nature13545

Pershing AJ et al. (2015) Slow adaptation in the face of rapid warming leads to collapse of the Gulf of Maine cod fishery. Science, 350:809-812. https://doi.org/10.1126/science. aac 9819

Petersen CP, Reddien PW (2009) Wnt signaling and the polarity of the primary body axis. Cell 139:1056-1068. https://doi. org/10.1016/j.cell.2009.11.035

Peterson RH, Martin-Robichaud DJ (1989) First feeding of Atlantic salmon (Salmo salar L.) fry as influenced by temperature regime Aquaculture 78:35-53. https://doi.org/ 10.1016/0044-8486(89)90004-5

Peterson RH, Spinney HCE, Sreedharan A (1977) Development of Atlantic salmon (Salmo salar) eggs and alevins under varied temperature regimes Journal of the Fisheries
Research Board of Canada 34:31-43. https://doi.org/10. 1139/f77-004

Peyronnet A, Friedland KD (2008) Ó Maoileidigh N Different ocean and climate factors control the marine survival of wild and hatchery Atlantic salmon Salmo salar in the northeast Atlantic Ocean. J Fish Biol 73:945-962. https://doi. org/10.1111/j.1095-8649.2008.01984.x

Piché J, Hutchings JA, Blanchard W (2008) Genetic variation in threshold reaction norms for alternative reproductive tactics in male Atlantic salmon Salmo salar. Proc R Socy B Biol Sci 275:1571-1575. https://doi.org/10.1098/rspb. 2008.0251

Piront ML, Schmidt R (1988) Inhibition of long-term memory formation by anti-ependymin antisera after active shockavoidance learning in goldfish. Brain Res 442:53-62. https://doi.org/10.1016/0006-8993(88)91431-x

Planas JV, Swanson P (1995) Maturation-associated changes in the response of the salmon testis to the steroidogenic actions of gonadotropins (GTH I and GTH II) in vitro. Biol Reprod, 52:697-704. https://doi.org/10.1095/ biolreprod52.3.697

Plusa B, Hadjantonakis A-K (2018) Cell Fate in Mammalian Development. Elsevier Academic Press Inc., Cambridge

Pohja-Mykrä M, Matilainen A, Kujala S, Hakala O, Harvio V, Törmä H, Kurki S (2018) Erätalouteen liittyvän yritystoiminnan nykytila ja kehittämisedellytykset. https:// julkaisut.valtioneuvosto.fi/handle/10024/160877

Pokki H, Artell J, Mikkola J, Orell P, Ovaskainen V (2018) Valuing recreational salmon fishing at a remote site in Finland: A travel cost analysis. Fish Res 208:145-156. https://doi.org/10.1016/j.fishres.2018.07.013

Power G (1958) The evolution of the freshwater races of the Atlantic salmon (Salmo salar L.) in eastern North America Arctic 11:86-92. https://doi.org/10.14430/arctic3735

Prat F, Sumpter JP, Tyler CR (1996) Validation of radioimmunoassays for two salmon gonadotropins (GTH I and GTH II) and their plasma concentrations throughout the reproductivecycle in male and female rainbow trout (Oncorhynchus mykiss). Biol Reprod, 54:1375-1382. https:// doi.org/10.1095/biolreprod54.6.1375

Pritchard VL, Mäkinen H, Vähä J-P, Erkinaro J, Orell P, Primmer CR (2018) Genomic signatures of fine-scale local adaptation in Atlantic salmon suggest involvement of sexual maturation, energy homeostatsis, behaviour and immune defence-related genes. Mol Ecol. https://doi.org/ $10.1101 / 271528$

Quinn TP (1993) A review of homing and straying of wild and hatchery-produced salmon. Fish Res 18:29-44. https://doi. org/10.1016/0165-7836(93)90038-9

Quinn TP, McGinnity P, Cross TF (2006) Long-term declines in body size and shifts in run timing of Atlantic salmon in Ireland. J Fish Biol:1713-1730. https://doi.org/10.1111/j. 1095-8649.2006.01017.x

Radchuk V et al (2019) Adaptive responses of animals to climate change are most likely insufficient. Nat Commun 10:3109. https://doi.org/10.1038/s41467-019-10924-4

Reed TE, Prodöhl P, Bradley C, Gilbey J, McGinnity P, Primmer CR, Bacon PJ (2018) Heritability estimation via molecular pedigree reconstruction in a wild fish population reveals substantial evolutionary potential for sea-age at 
maturity, but not size within age-classes. Canadian J Fish Aquat Sci. https://doi.org/10.1139/cjfas-2018-0123

Reinton N, Collas P, Haugen TB, Skålhegg BS, Hansson V, Jahnsen T, Taskén K (2000) Localization of a novel human A-kinase-anchoring protein, hAKAP220, during spermatogenesis. Develop Biol, 223:194-204. https://doi.org/ 10.1006/dbio.2000.9725

Reznick DN, Ghalambor CK (2005) Can commercial fishing cause evolution? Answers from guppies (Poecilia reticulata). Canadian J Fish Aquat Sci 62:791-801. https://doi. org/10.1139/f05-079

Reznick D, Bryant M, Holmes D (2006) The evolution of senescence and post-reproductive lifespan in guppies (Poecilia reticulata). PLoS Biol 4:e7-e7. https://doi.org/ 10.1371/journal.pbio.0040007

Richard A, Dionne M, Wang J, Bernatchez L (2013) Does catch and release affect the mating system and individual reproductive success of wild Atlantic salmon (Salmo salar L.)? Mol Ecol 22:187-200. https://doi.org/10.1111/mec. 12102

Rikardsen AH et al (2004) Geographical differences in marine feeding of Atlantic salmon post-smolts in Norwegian fjords. J Fish Biol 64:1655-1679. https://doi.org/10.1111/j. 1095-8649.2004.00425.x

Rikardsen AH, Dempson JB (2010) Dietary life-support: the food and feeding of Atlantic salmon at sea. In: Aas $\varnothing$, Einum S, Klemetsen A, Skurdal J (eds) Atlantic Salmon Ecology. Wiley-Blackwell, pp 115-143. https://doi.org/10. 1002/9781444327755.ch5

Roff DA (1993) Evolution of Life Histories: Theory and Analysis. Chapman \& Hall, New York

Rowe DK, Thorpe JE, Shanks AM (1991) Role of fat stores in the maturation of male Atlantic salmon (Salmo salar) parr. Canadian J Fish Aquat Sci, 48:405-413. https://doi.org/10. 1139/f91-052

Sakai N, Ueda H, Suzuki N, Nagahama Y (1989) Steroid production by amago salmon (Oncorhynchus rhodurus) testes at different development stages Gen Comp Endocrinol 75:231-240. https://doi.org/10.1016/00166480(89)90075-0

Salminen M (1997) Relationships between smolt size, postsmolt growth and sea age at maturity in Atlantic salmon ranched in the Baltic Sea. J Appl Ichthyol 13:121-130. https://doi. org/10.1111/j.1439-0426.1997.tb00111.x

Salminen M, Erkamo E, Salmi J (2001) Diet of post-smolt and one-sea-winter Atlantic salmon in the Bothnian Sea. Northern Baltic 58:16-35. https://doi.org/10.1111/j.10958649.2001.tb00496.x

Sambroni E, Rolland AD, Lareyre J-J, Le Gac F (2013) Fsh and Lh have common and distinct effects on gene expression in rainbow trout testis. J Mol Endocrinol 50:1-18. https://doi. org/10.1530/JME-12-0197

Saunders RL, Henderson EB (1970) Influence of photoperiod on smolt development and growth of Atlantic salmon (Salmo solar). J Fish Res Board Canada 27:1295-1311. https://doi. org/10.1139/f70-151

Saunders MW, McFarlane GA (1993) Age and length at maturity of the female spiny dogfish, Squalus acanthias, in the Strait of Georgia, British Columbia, Canada. Environ Biol Fishes 38:49-57. https://doi.org/10.1007/BF00842903
Saura M, Caballero A, Caballero P, Morán P (2008) Impact of precocious male parr on the effective size of a wild population of Atlantic salmon. Freshw Biol 53:2375-2384. https://doi.org/10.1111/j.1365-2427.2008.02062.x

Schindler DE, Hilborn R, Chasco B, Boatright CP, Quinn TP, Rogers LA, Webster MS (2010) Population diversity and the portfolio effect in an exploited species. Nature 465:609. https://doi.org/10.1038/nature09060

Schindler DE, Armstrong JB, Reed TE (2015) The portfolio concept in ecology and evolution. Front Ecol Environ 13:257-263. https://doi.org/10.1890/140275

Schulz RdW (2005) Menting S, Bogerd J, França LR, Vilela DAR, Godinho HP Sertoli cell proliferation in the adult testis-evidence from two fish species belonging to different orders. Biol Reprod 73:891-898. https://doi.org/10. 1095/biolreprod.105.039891

Schulz RW, Andersson E, Taranger GL (2006) Photoperiod manipulation can stimulate or inhibit pubertal testis maturation in Atlantic salmon (Salmo salar). Animal Reprod 3:121-126

Schulz RW, Taranger GL, Bogerd J, Nijenhuis W, Norberg B, Male R, Andersson E (2019) Entry into puberty is reflected in changes in hormone production but not in testicular receptor expression in Atlantic salmon (Salmo salar). Reproduct Biol Endocrinol 17:48. https://doi.org/10.1186/ s12958-019-0493-8

Scott AP, Sheldrick EL, Flint AP (1982) Measurement of 17 alpha, 20 beta-dihydroxy-4-pregnen-3-one in plasma of trout (Salmo gairdneri Richardson): seasonal changes and response to salmon pituitary extract. Gen Comp Endocrinol 46:444-451. https://doi.org/10.1016/00166480(82)90098-3

Seear PJ, Carmichael SN, Talbot R, Taggart JB, Bron JE, Sweeney GE (2010) Differential gene expression during smoltification of Atlantic Salmon (Salmo salar L.): a first large-scale microarray study. Mar Biotechnol 12:126-140. https://doi.org/10.1007/s10126-009-9218-x

Shearer WM (1990) The Atlantic salmon (Salmo salar L.) of the North Esk with particular reference to the relationship between both river and sea age and time of return to home waters. Fish Res 10:93-123. https://doi.org/10.1016/01657836(90)90017-P

Sheridan MA (1989) Alterations in lipid metabolism accompanying smoltification and seawater adaptation of salmonid fish. Aquaculture 82:191-203. https://doi.org/10.1016/ 0044-8486(89)90408-0

Sheridan MA, Harmon JS (1994) Adipose tissue. In: Hochachka PW, Mommsen TP (eds) Biochemistry and molecular biology of fishes, vol 3. vol Analytical Techniques. Elsevier, pp 305-311. https://doi.org/10.1016/B978-0-44482033-4.50032-5

Silverstein JT, Shimma H, Ogata H (1997) Early maturity in amago salmon (Oncorhynchus masu ishikawai): an association with energy storage. Canadian J Fish Aquat Sci 54:444-451. https://doi.org/10.1139/f96-284

Simon E, Thézé N, Fédou S, Thiébaud P, Faucheux C (2017) Vestigial-like 3 is a novel Ets1 interacting partner and regulates trigeminal nerve formation and cranial neural crest migration. Biol Open 6:1528. https://doi.org/10.1242/ bio.026153 
Sinclair-Waters M, Ødegård J, Korsvoll SA, Moen T, Lien S, Primmer CR, Barson NJ (2020) Beyond large-effect loci: large-scale GWAS reveals a mixed large-effect and polygenic architecture for age at maturity of Atlantic salmon. Genet Sel Evol 52:9. https://doi.org/10.1186/s12711-0200529-8

Skaala $\varnothing$ et al (2019) An extensive common-garden study with domesticated and wild Atlantic salmon in the wild reveals impact on smolt production and shifts in fitness traits. Evol Appl 12:1001-1016. https://doi.org/10.1111/eva.12777

Skaar KS, Nóbrega RH, Magaraki A, Olsen LC, Schulz RW, Male R (2011) Proteolytically activated, recombinant antiMüllerian hormone inhibits Androgen secretion, proliferation, and differentiation of spermatogonia in adult zebrafish testis organ cultures. Endocrinology 152:3527-3540. https://doi.org/10.1210/en.2010-1469

Skaftnesmo KO et al (2017) Integrative testis transcriptome analysis reveals differentially expressed miRNAs and their mRNA targets during early puberty in Atlantic salmon. BMC Genomics 18:801. https://doi.org/10.1186/s12864017-4205-5

Spear MJ, Embke HS, Krysan PJ, Vander Zanden MJ (2020) Application of eDNA as a tool for assessing fish population abundance. Environ DNA n/a. https://doi.org/10.1002/ edn3.94

Specker JL, Eales JG, Tagawa M (2000) Tyler IIIWA Parr-smolt transformation in Atlantic salmon: thyroid hormone deiodination in liver and brain and endocrine correlates of change in rheotactic behavior. Canadian $\mathrm{J}$ Zool 78:696-705. https://doi.org/10.1139/z99-258

Sprent J, Jones SM, Nicol SC (2012) Does leptin signal adiposity in the egg-laying mammal, Tachyglossus aculeatus? Gen Comp Endocrinol 178:372-379. https://doi.org/10. 1016/j.ygcen.2012.06.021

Stead SM, Houlihan DF, McLay HA, Johnstone R (1999) Food consumption and growth in maturing Atlantic salmon (Salmo salar). Canadian J of Fish Aquat Sci 56:2019-2028. https://doi.org/10.1139/f99-136

Stearns SC (1992) The Evolution of Life Histories. Oxford University, Oxford, UK

Stewart DC, Smith GW, Youngson AF (2002) Tributaryspecific variation in timing of return of adult Atlantic salmon (Salmo salar) to fresh water has a genetic component. Canadian J Fish Aquat Sci 59:276-281. https://doi.org/10. 1139/f02-011

Strøm JF et al (2019) Ocean predation and mortality of adult Atlantic salmon. Sci Rep 9:7890-7890. https://doi.org/10. 1038/s41598-019-44041-5

Strøm JF, Thorstad EB, Hedger RD, Rikardsen AH (2018) Revealing the full ocean migration of individual Atlantic salmon. Animal Biotelem. https://doi.org/10.1186/s40317018-0146-2

Sundt-Hansen LE et al (2018) Modelling climate change effects on Atlantic salmon: Implications for mitigation in regulated rivers. Sci Total Environ 631-632:1005-1017. https://doi.org/10.1016/j.scitotenv.2018.03.058

Suuronen P, Jounela P (2010) Introducing run-size driven fisheries management for the coastal fishery of Atlantic salmon: Preseason forecasts for policy makers. Mar Policy 34:679-689. https://doi.org/10.1016/j.marpol.2009.12.009
Suzuki K, Kanamori A, Nagahama Y, Kawauchi H (1988) Development of salmon GTH I and GTH II radioimmunoassays. Gen Comp Endocrinol 71:459-467. https:// doi.org/10.1016/0016-6480(88)90275-4

Suzuki K, Nagahama Y, Kawauchi H (1988) Steroidogenic activities of two distinct salmon gonadotropins. Gen Comp Endocrinol 71:452-458

Taborsky B (2008) Alternative reprodutive tactics in fish. In: Oliveira R, Taborsky M, Brockmann HJ (eds) Alternative reproductive tactics: an introgrative approach. Cambridge University Press, Cambridge, pp 251-299

Taggart JB, McLaren IS, Hay DW, Webb JH, Youngson AF (2001) Spawning success in Atlantic salmon (Salmo salar L): a long-term DNA profiling-based study conducted in a natural stream. Mol Ecol 10:1047-1060. https://doi.org/10. 1046/j.1365-294X.2001.01254.X

Takahashi A, Kobayashi Y, Amano M, Yamanome T (2009) Structural and functional diversity of proopiomelanocortin in fish with special reference to barfin flounder. Peptides 30:1374-1382. https://doi.org/10.1016/j.peptides.2009.04. 014

Taranger GL et al (2010) Control of puberty in farmed fish. Gen Comp Endocrinol 165:483-515. https://doi.org/10.1016/j. ygcen.2009.05.004

Taranger GL, Hansen T (1993) Ovulation and egg survival following exposure of Atlantic salmon, Salmo salar L., broodstock to different water temperatures. Aquacult Fish Manag 24:151-156. https://doi.org/10.1111/j.1365-2109. 1993.tb00535.x

Taranger GL, Haux C, Hansen T, Stefansson SO, Björnsson BT, Walther BT, Kryvi H (1999) Mechanisms underlying photoperiodic effects on age at sexual maturity in Atlantic salmon. Salmo salar Aquacult 177:47-60. https://doi.org/ 10.1016/S0044-8486(99)00068-X

Tentelier C, Lepais O, Larranaga N, Manicki A, Lange F, Rives J (2016) Sexual selection leads to a tenfold difference in reproductive success of alternative reproductive tactics in male Atlantic salmon. Sci Nat 103:47. https://doi.org/10. 1007/s00114-016-1372-1

Teo JL, Kahn M (2010) The Wnt signaling pathway in cellular proliferation and differentiation: a tale of two coactivators. Adv Drug Deliv Rev 62:1149-1155. https://doi.org/10. 1016/j.addr.2010.09.012

Thomaz D, Beall E, Burke T (1997) Alternative reproductive tactics in atlantic salmon: factors affecting mature parr success. Proc R Soc London Ser B Biol Sci 264:219-226. https://doi.org/10.1098/rspb.1997.0031

Thorpe JE (1986) Age at first maturity in Atlantic salmon, Salmo salar: freshwater period influences and conflicts with smolting. In: Meerburg DJ (ed) Salmonid Age at Maturity, vol 89. Canadian Special Publications in Fisheries and Aquatic Science. National Research Council of Canada, Ottawa, Canada, pp 7-14

Thorpe JE (1994) Reproductive strategies in Atlantic salmon Salmo salar L. Aquacult Res 25:77-87. https://doi.org/10. 1111/j.1365-2109.1994.tb00668.x

Thorpe JE (2007) Maturation responses of salmonids to changing developmental opportunities. Mar Ecol Prog Ser 335:285-288. https://doi.org/10.3354/meps335285

Thorpe JE, Metcalfe NB (1998) Is smolting a positive or a negative developmental decision? Aquaculture 
168:95-103. 8486(98)00342-1

https://doi.org/10.1016/S0044-

Thorpe JE, Morgan RIG (1980) Growth-rate and smolting-rate of progeny of male Atlantic salmon parr Salmo salar L. J Fish Biol 17:451-460. https://doi.org/10.1111/j.10958649.1980.tb02778.x

Thorpe JE, Ross LG, Struthers G, Watts W (1981) Tracking Atlantic salmon smolts, Salmo salar L., through Loch Voil. Scotland J Fish Biol 19:519-537. https://doi.org/10.1111/j. 1095-8649.1981.tb03820.x

Thorpe JE, Mangel M, Metcalfe NB, Huntingford FA (1998) Modelling the proximate basis of salmonid life-history variation, with application to Atlantic salmon Salmo salar L. Evol Ecol 12:581-599. https://doi.org/10.1023/A: 1022351814644

Thorstad EB, Økland F, Aarestrup K, Heggberget TG (2008) Factors affecting the within-river spawning migration of Atlantic salmon, with emphasis on human impacts. Rev Fish Biol Fish 18:345-371. https://doi.org/10.1007/ s11160-007-9076-4

Tilman D, Lehman Clarence L, Bristow Charles E (1998) Diversity-stability relationships: statistical inevitability or ecological consequence? Am Nat 151:277-282. https://doi. org/10.1086/286118

Todd CD, Hughes SL, Marshall CT, MacLean JC, Lonergan ME, Biuw EM (2008) Detrimental effects of recent ocean surface warming on growth condition of Atlantic salmon 14:958-970. https://doi.org/10.1111/j.1365-2486.2007. 01522.x

Trombley S, Mustafa A, Schmitz M (2014) Regulation of the seasonal leptin and leptin receptor expression profile during early sexual maturation and feed restriction in male Atlantic salmon, Salmo salar L., parr. Gen Comp Endocrinol 204:60-70. https://doi.org/10.1016/j.ygcen.2014.04. 033

Tu W, Wagner EK, Eckert GJ, Yu Z, Hannon T, Pratt JH, He C (2015) Associations between menarche-related genetic variants and pubertal growth in male and female adolescents. J Adolesc Health 56:66-72. https://doi.org/10.1016/ j.jadohealth.2014.07.020

Ueda H, Young G, Crim LW, Kambegawa A, Nagahama Y (1983) 17alpha,20beta-dihydroxy-4-pregnen-3-one: plasma levels during sexual maturation and in vitro production by the testes of amago salmon (Oncorhynchus rhodurus) and rainbow trout (Salmo gairdneri). Gen Comp Endocrinol 51:106-112. https://doi.org/10.1016/00166480(83)90103-x

Uusi-Heikkilä S et al (2015) The evolutionary legacy of sizeselective harvesting extends from genes to populations. Evol Appl 8:597-620. https://doi.org/10.1111/eva.12268

Vähä J-P et al (2011) Temporally stable population-specific differences in run timing of one-sea-winter Atlantic salmon returning to a large river system. Evol Appl 4:39-53. https://doi.org/10.1111/j.1752-4571.2010.00131.x

Vähä J-P, Erkinaro J, Niemelä E, Primmer CR (2007) Lifehistory and habitat features influence the within-river genetic structure of Atlantic salmon. Mol Ecol 16:2638-2654. https://doi.org/10.1111/j.1365-294X.2007. 03329.x

Vähä J-P, Erkinaro J, Falkegård M, Orell P, Niemelä E (2017) Genetic stock identification of Atlantic salmon and its evaluation in a large population complex. Can J Fish Aquat Sci 74:327-338. https://doi.org/10.1139/cjfas-2015-0606

Van Leeuwen TE, McLennan D, McKelvey S, Stewart DC, Adams CE, Metcalfe NB (2016) The association between parental life history and offspring phenotype in Atlantic salmon. J Exp Biol 219:374. https://doi.org/10.1242/jeb. 122531

Varelas X et al (2010) The Hippo pathway regulates Wnt/betacatenin signaling. Dev Cell 18:579-591. https://doi.org/10. 1016/j.devcel.2010.03.007

Veale AJ, Russello MA (2017) An ancient selective sweep linked to reproductive life history evolution in sockeye salmon. Sci Rep 7:1-10. https://doi.org/10.1038/s41598017-01890-2

Verta J-P et al (2020) Cis-regulatory differences in isoform expression associate with life history strategy varation in Atlantic salmon. PLOS Genetics 16:e1009055. https://doi. org/10.1371/journal.pgen.1009055

Veselov AE, Kazakov RV, Sysoyeva MI, Bahmet IN (1998) Ontogenesis of rheotactic and optomotor responses of juvenile Atlantic salmon. Aquaculture 168:17-26. https:// doi.org/10.1016/S0044-8486(98)00362-7

Vladić TV (2001) Sperm quality in the alternative reproductive tactics of Atlantic salmon: the importance of the loaded raffle mechanism. Proc R Soc London Ser B Biol Sci 268:2375

Vladić TV, Afzelius BrA, Bronnikov GE, (2002) Sperm quality as reflected through morphology in salmon alternative life histories. Biol Reprod 66:98-105. https://doi.org/10.1095/ biolreprod66.1.98

von Schalburg KR et al (2011) Regulation and expression of sexual differentiation factors in embryonic and extragonadal tissues of Atlantic salmon. BMC Genomics 12:31-31. https://doi.org/10.1186/1471-2164-12-31

Vornanen M, Paajanen V (2006) Seasonal changes in glycogen content and $\mathrm{Na}+\mathrm{K}+-\mathrm{ATPase}$ activity in the brain of crucian carp. Am J Physiol Regul Integr Comp Physiol 291:R1482-1489. https://doi.org/10.1152/ajpregu.00172. 2006

Vrtílek M, Žák J, Pšenička M, Reichard M (2018) Extremely rapid maturation of a wild African annual fish. Curr Biol 28:R822-R824. https://doi.org/10.1016/j.cub.2018.06.031

Waters CD, Clemento A, Aykanat T, Garza JC, Naish KA, Narum S, Primmer CR (2021) Heterogeneous genetic basis of age at maturity in salmonid fishes. Mol Ecol 30:1435-1456. https://doi.org/10.1111/mec.15822

Webb JH, McLay HA (1996) Variation in the time of spawning of Atlanticsalmon (Salmo salar) and its relationship totemperature in the Aberdeenshire Dee Scotlan. Canadian J Fish Aquat Sci 53:2739-2744. https://doi.org/10.1139/ f96-240

Webb J, Verspoor E, Aubin-Horth N, Romakkaniemi A, Amiro P (2007) The Atlantic salmon. In: Verspoor E, Stradmeyer L, Nielsen JL (eds) The Atlantic Salmon: Genetics, Conservation and Management. Blackwell Publishing Ltd., Oxford, pp 17-56. https://doi.org/10.1002/ 9780470995846.ch2

Weir LK, Breau C, Hutchings JA, Cunjak RA (2010) Multiple paternity and variance in male fertilization success within Atlantic salmon Salmo salar redds in a naturally spawning 
population. J Fish Biol 77:479-493. https://doi.org/10. 1111/j.1095-8649.2010.02690.x

Whalen KG, Parrish DL (1999) Effect of maturation on parr growth and smolt recruitment of Atlantic salmon. Can J Fish Aquat Sci 56:79-86. https://doi.org/10.1139/f98-154

Whittington CM, Wilson AB (2013) The role of prolactin in fish reproduction. Gen Comp Endocrinol 191:123-136. https:// doi.org/10.1016/j.ygcen.2013.05.027

Willis SC, Hess JE, Fryer JK, Whiteaker JM, Brun C, Gerstenberger R, Narum SR (2020) Steelhead (Oncorhynchus mykiss) lineages and sexes show variable patterns of association of adult migration timing and age-at-maturity traits with two genomic regions. Evol Appl 13:2836-2856. https://doi.org/10.1111/eva.13088

Xie $\mathrm{H}$ et al (2015) Homeodomain Proteins SIX3 and SIX6 Regulate Gonadotrope-specific Genes During Pituitary Development. Mol Endocrinol 29:842-855. https://doi. org/10.1210/me.2014-1279
Yan L, Swanson P, Dickhoff WW (1992) A two-receptor model for salmon gonadotropins (GTH I and GTH II). Biol Reprod 47:418-427. https://doi.org/10.1095/biolreprod47. 3.418

Young G, Crim LW, Kagawa H, Kambegawa A, Nagahama Y (1983) Plasma 17 alpha, 20 beta-dihydroxy-4-pregnen-3one levels during sexual maturation of amago salmon (Oncorhynchus rhodurus): correlation with plasma gonadotropin and in vitro production by ovarian follicles. Gen Comp Endocrinol 51:96-105. https://doi.org/10.1016/ 0016-6480(83)90102-8

Publisher's Note Springer Nature remains neutral with regard to jurisdictional claims in published maps and institutional affiliations. 